Cover. Block diagram of hypothetical area showing hydrology of mined and unmined areas (modified from Hobba, 1981, fig. 4.0-B). 


\section{Simulation of Rainfall-Runoff Response in Mined and Unmined Watersheds in Coal Areas of West Virginia}

By CELSO PUENTE and JOHN T. ATKINS

Prepared in cooperation with the

U.S. BUREAU OF LAND MANAGEMENT 


\section{DEPARTMENT OF THE INTERIOR}

MANUEL LUJAN, Jr., Secretary

\section{U.S. GEOLOGICAL SURVEY}

Dallas L. Peck, Director

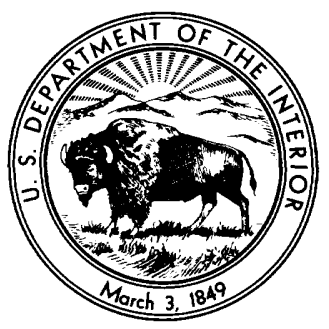

Any use of trade, product, or firm names in this publication is for descriptive purposes only and does not imply endorsement by the U.S. Government

For sale by the Books and Open-File Reports Section, U.S. Geological Survey, Federal Center, Box 25425, Denver, CO 80225

\section{Library of Congress Cataloging in Publication Data}

Puente, Celso.

Simulation of rainfall-runoff response in mined and unmined watersheds in coal areas of West Virginia.

(Water-supply paper ; 2298)

"Prepared in cooperation with the U.S. Bureau of Land Management." Bibliography: $p$.

Supt. of Docs. No: I 19.13:2298

1. Rain and rainfall-West Virginia. 2. Runoff-West Virginia. 3. Coal mines and mining-Environmental aspects-West Virginia. I. Atkins, John T. II. Title. III. United States. Bureau of Land Management. IV. Series: Geological Survey water-supply paper ; 2298.

QC925.1.U8W457 $1989 \quad 551.48^{\prime} 8$ ly

$87-600216$ 


\title{
CONTENTS
}

\author{
Abstract 1 \\ Introduction 1 \\ Background 1 \\ Purpose and scope $\mathbf{2}$ \\ Description of study area 2 \\ Environmental setting $\mathbf{2}$ \\ Physiography and topography $\mathbf{2}$ \\ Geology 2 \\ Climate 3 \\ Soils 4 \\ Land use 7 \\ Effects of coal mining on the hydrologic system $\mathbf{1 1}$ \\ Drawdy Creek 11 \\ Brier Creek 14 \\ Simulation of rainfall-runoff response in mined and unmined watersheds in coal \\ areas 14 \\ Description of model 14 \\ Model characteristics 14 \\ Data requirements $\mathbf{1 7}$ \\ Model calibration and verification 19 \\ Model simulations 20 \\ Historic conditions 20 \\ Streamflow 20 \\ Water budget 28 \\ Hypothetical conditions $\mathbf{3 0}$ \\ Streamflow $\mathbf{3 0}$ \\ Water budget $\mathbf{3 4}$ \\ Summary and conclusions $\mathbf{3 4}$ \\ References cited $\mathbf{4 0}$ \\ Appendix A-Precipitation-Runoff Modeling System parameters and variables \\ Metric conversion factors $\mathbf{4 8}$
}

\section{FIGURES}

1. Map showing areas of study and extent of minable coal in West Virginia 3

2. Generalized geologic map $\mathbf{5}$

3. Map showing distribution of mean annual precipitation (1941-70) and monthly precipitation and temperature for selected sites (1931-73) 6

4-8. Maps showing:

4. Physical features in Horsecamp Run basin 7

5. Physical features in Gilmer Run basin $\mathbf{8}$

6. Physical features in Collison Creek basin 9

7. Coal-mined areas in Drawdy Creek basin $\mathbf{1 0}$

8. Coal-mined areas in Brier Creek basin $\mathbf{1 2}$

9. Schematic diagram showing relation between dip of coal, location and condition of abandoned underground mines, and movement of water 13 
10. Hydrographs showing basin peak-flow response to storm of November 197914

11, 12. Maps showing:

11. Base-flow yield in Drawdy Creek basin, February $1983 \quad 15$

12. Base-flow yield in Brier Creek basin, March $1983 \quad 16$

13. Schematic diagram of the watershed model $\mathbf{1 7}$

14. Flowchart of the digital watershed model $\mathbf{1 8}$

15-19. Hydrographs showing observed and simulated daily mean streamflow at:

15. Horsecamp Run at Harman, October 1971-September 197221

16. Gilmer Run near Marlinton, October 1971-September 197221

17. Collison Creek near Nallen, October 1971-September 197222

18. Drawdy Creek near Peytona, October 1969-September $1970 \quad 22$

19. Brier Creek at Fanrock, October 1971-September 197223

20. Hydrographs showing observed and simulated monthly mean discharge at study basins, 1969-76 25

21-25. Graphs showing duration curves of daily mean discharge at:
21. Horsecamp Run at Harman, 1972-76 28
22. Gilmer Run near Marlinton, 1971-74 28
23. Collison Creek near Nallen, 1972-76 29
24. Drawdy Creek near Peytona, 1970-74 29
25. Brier Creek at Fanrock, 1971-73 30

26. Schematic diagrams showing approximate percentages of simulated waterbudget components for mined and unmined basins, October 1, 1971, to September 30, $1973 \mathbf{3 1}$

27-30. Graphs showing:

27. Duration curves of daily mean streamflow simulated under various mining conditions at Drawdy Creek near Peytona, 1970-74 33

28. Duration curves of daily mean streamflow simulated under various mining conditions at Brier Creek at Fanrock, 1971-73 33

29. Seasonal distribution of components of average total monthly runoff simulated at Drawdy Creek near Peytona, 1970-74 37

30. Seasonal distribution of components of average total monthly runoff simulated at Brier Creek at Fanrock, 1971-73 38

\section{TABLES}

1. Small-basin gaging stations 4

2. Summary of major land uses $\mathbf{8}$

3. Summary of selected characteristics of the hydrologic-response units used in the model 19

4. Summary of annual precipitation, observed and simulated annual runoff, and associated error for the period of simulated record $\mathbf{2 4}$

5. Summary of observed and simulated monthly and annual runoff during calibration and verification period of record for study basins 26

6. Summary of water budget simulated for study basins $\mathbf{3 2}$

7. Simulated water budgets for Drawdy Creek and Brier Creek basins under various mining conditions $\mathbf{3 5}$ 


\title{
Simulation of Rainfall-Runoff Response in Mined and Unmined Watersheds in Coal Areas of West Virginia
}

\author{
By Celso Puente and John T. Atkins
}

\begin{abstract}
Meteorologic and hydrologic data from five small watersheds in the coal areas of West Virginia were used to calibrate and test the U.S. Geological Survey PrecipitationRunoff Modeling System for simulating streamflow under various climatic and land-use conditions. Three of the basins-Horsecamp Run, Gilmer Run, and Collison Creek-are primarily forested and relatively undisturbed. The remaining basins-Drawdy Creek and Brier Creekare extensively mined, both surface and underground above stream drainage level.

Low-flow measurements at numerous synoptic sites in the mined basins indicate that coal mining has substantially altered the hydrologic system of each basin. The effects of mining on streamflow that were identified are (1) reduced base flow in stream segments underlain by underground mines, (2) increased base flow in streams that are downdip and stratigraphically below the elevation of the mined coal beds, and (3) interbasin transfer of ground water through underground mines. These changes probably reflect increased permeability of surface rocks caused by subsidence fractures associated with collapsed underground mines in the basin. Such fractures would increase downward percolation of precipitation, surface and subsurface flow, and ground-water flow to deeper rocks or to underground mine workings.

Model simulations of the water budgets for the unmined basins during the 1972-73 water years indicate that total annual runoff averaged 60 percent of average annual precipitation; annual evapotranspiration losses averaged 40 percent of average annual precipitation. Of the total annual runoff, approximately 91 percent was surface and subsurface runoff and 9 percent was groundwater discharge. Changes in storage in the soil zone and in the subsurface and ground-water reservoirs in the basins were negligible.

In contrast, water-budget simulations for the mined basins indicate significant differences in annual recharge and in total annual runoff. Model simulations of the water budget for Drawdy Creek basin indicate that total annual runoff during $1972-73$ averaged only 43 percent of average
\end{abstract}

Manuscript approved for publication September 19. 1987. annual precipitation-the lowest of all study basins; annual evapotranspiration losses averaged 49 percent, and interbasin transfer of ground-water losses averaged about 8 percent. Of the total annual runoff, approximately 74 percent was surface and subsurface flow and 26 percent was ground-water discharge. The low total annual runoff at Drawdy Creek probably reflects increased recharge of precipitation and surface and subsurface flow losses to ground water. Most of the increase in ground-water storage is, in turn, lost to a ground-water sink-namely, interbasin transfer of ground water by gravity drainage and (or) mine pumpage from underground mines that extend to adjacent basins.

Hypothetical mining situations were posed for model analysis to determine the effects of increased mining on streamflow in the mined basins. Results of model simulations indicate that streamflow characteristics, the water budget, and the seasonal distribution of streamflow would be significantly modified in response to an increase in mining in the basins. Simulations indicate that (1) total annual runoff in the basins would decrease because of increased surface- and subsurface-flow losses and increased recharge of precipitation to ground water (these losses would tend to reduce medium to high flows mainly during winter and spring when losses would be greatest), (2) extreme high flows in response to intense rainstorms would be negligibly affected, regardless of the magnitude of mining in the basins, (3) ground-water discharge also would decrease during winter and spring, but the amount and duration of low flows during summer and fall would substantially increase in response to increased ground-water storage in rocks and in underground mines, and (4) the increase in ground-water storage in the basins would be depleted, mostly by increased losses to a ground-water sink.

\section{INTRODUCTION}

\section{Background}

Maximum development of coal as a source of energy will require the mining of extensive Federal reserves in the coal areas of Appalachia. In anticipation of this mining, an 
assessment of the effect of underground and surface coal mining on the hydrology of mined and adjacent unmined basins is needed to aid Federal managers in preparing environmental impact statements and in monitoring mining and reclamation activities. These assessments include the definition of streamflow regimes, flood peaks and volumes, low flows, soil-water relations, ground-water flow (including recharge and discharge), and water-balance relations for basins before, during, and after mining.

Unfortunately, much of the information needed to define the hydrology of mined and unmined basins in most of the coal areas of Appalachia is short-term and the data are sparse. Long-term streamflow records are available at selected gaging stations; however, the information is site specific, and its transferability to nearby ungaged areas is unknown.

Hydrologic models are analytical tools that can provide a means for (1) describing the hydrologic system of small watersheds, (2) extending streamflow records at short-term gaging stations, and (3) transferring hydrologic characteristics from gaged areas to ungaged areas. In 1981, the U.S. Geological Survey, in cooperation with the U.S. Bureau of Land Management, began a study to test the application of the U.S. Geological Survey's PrecipitationRunoff Modeling System for simulating streamflow in small watersheds (mined and unmined) in the coal areas of West Virginia.

\section{Purpose and Scope}

The objectives of the study were to (1) calibrate and verify the U.S. Geological Survey's Precipitation-Runoff Modeling System for simulating streamflow under various climatic and land-use conditions, and (2) apply the model under various hypothetical mining conditions to predict possible hydrologic consequences for streamflow. This is only the first step in providing to the U.S. Bureau of Land Management a technique for describing the hydrology of ungaged areas and a means for predicting the effects of coal mining on the hydrologic system of basins in the coal areas of West Virginia.

Model testing at five study basins - three unmined and two mined-shown in figure 1 was based on 3 to 5 years of climatic and hydrologic data collected during 1969-75 as part of a previous hydrologic investigation by Runner (1980). To determine the effects of coal mining on the quantity and distribution of streamflow in the mined basins, streamflow data at numerous synoptic sites were collected during medium- to high-base-flow conditions in February and March 1983. This report describes (1) the results of low-flow measurements in the mined study basins, (2) the calibration and verification of the precipitation-runoff model, and (3) the possible consequences of various hypothetical coal-mining scenarios for streamflow and basin storage.

\section{DESCRIPTION OF STUDY AREA}

\section{Environmental Setting}

Five small basins having drainage areas ranging from 1.80 to 7.75 square miles in the coal areas of West Virginia (fig. 1) were selected for study. The study basins have similar topographic, geologic, and hydrologic settings but different land-use characteristics. Three of the basins are relatively undisturbed, and two have been surface mined and deep mined at elevations above the basin's major stream. Site and streamflow gaging station numbers, station name and location, drainage area, and period of record used for each study basin are listed in table 1 .

\section{Physiography and Topography}

The basins lie in the Kanawha section of the Appalachian Plateau physiographic province as defined by Fenneman and Johnson (1946). The topography is mountainous and is characterized by deep, steep-sided valleys and narrow, winding ridges.

The elevation of the five gaging stations ranges from 770 feet above sea level at Drawdy Creek (site 4) in the southwestern part of the State to 3,120 feet at Gilmer Run (site 2) in the east-central part of the State (fig. 1). Local relief ranges from 500 feet in Collison Creek basin (site 3) to 2,200 feet in Horsecamp Run basin (site 1).

Mean basin land slopes are gentlest (15 percent) in Collison Creek basin and greatest (27 percent) in Horsecamp Run. Main channel slopes range from 55 feet per mile in Drawdy Creek to 275 feet per mile in Gilmer Run.

\section{Geology}

Strata underlying the coal areas of the State (fig. 2) generally dip to the northwest and strike to the northeast, so that progressively older formations are exposed in the east. The regional dip and strike are modified locally by faults and gentle folds. Most of the study basins display outcrop patterns of nearly horizontal strata in which the younger rocks underlie the uplands and the older rocks underlie the stream valleys.

Drawdy Creek basin is underlain by rocks of the Kanawha Formation, and Collison Creek and Brier Creek basins (sites 3 and 5) are underlain by the New River Formation, which underlies the Kanawha Formation. These formations mainly make up the Pottsville sequence of Pennsylvanian age and are composed primarily of cyclic sequences of shale, siltstone, and sandstone, with interbeds of coal and underclays. Most of the coal in the State is found in this sequence of sedimentary rock.

Gilmer Run basin is underlain by rocks of the Mauch Chunk Formation of Mississippian age. The rocks also 
Table 1. Small-basin gaging stations

[Sites shown in fig. 1]

\begin{tabular}{|c|c|c|c|c|c|}
\hline $\begin{array}{l}\text { Site } \\
\text { number }\end{array}$ & $\begin{array}{l}\text { USGS } \\
\text { station } \\
\text { number }\end{array}$ & Station name & Location & $\begin{array}{l}\text { Drainage } \\
\text { area } \\
\left(\mathrm{mi}^{2}\right)\end{array}$ & $\begin{array}{l}\text { Period } \\
\text { of } \\
\text { record }\end{array}$ \\
\hline 1 & 03063600 & $\begin{array}{l}\text { Horsecamp Run at } \\
\text { Harman, W. Va. }\end{array}$ & $\begin{array}{l}\text { Lat } 38^{\circ} 54^{\prime} 51^{\prime \prime}, \text { long } 79^{\circ} 30^{\prime} 32^{\prime \prime} \text {, Randolph } \\
\text { County, on right bank } 1.0 \text { mile south- } \\
\text { east of Harman. Elevation of gage is } \\
2,511 \mathrm{ft} \text { above sea level. }\end{array}$ & 6.57 & $1972-76$ \\
\hline 2 & 03193830 & $\begin{array}{l}\text { Gilmer Run near } \\
\text { Marlinton, } \\
\text { W. Va. }\end{array}$ & $\begin{array}{l}\text { Lat } 38^{\circ} 19^{\prime} 12^{\prime \prime} \text {, long } 80^{\circ} 05^{\prime} 52^{\prime \prime} \text {, Pocahontas } \\
\text { County, on left bank } 8.0 \mathrm{ft} \text { upstream } \\
\text { from culvert on Forest Service Road } 251 \\
\text { and } 6.8 \text { miles north of Marlinton. } \\
\text { Elevation of gage is } 3,120 \mathrm{ft} \text { above sea } \\
\text { level. }\end{array}$ & 1.80 & $1971-74$ \\
\hline 3 & 03189650 & $\begin{array}{l}\text { Collison Creek } \\
\text { near Nallen, } \\
\text { w. Va. }\end{array}$ & $\begin{array}{l}\text { Lat } 38^{\circ} 10^{\prime} 35^{\prime \prime}, \text { long } 80^{\circ} 50^{\prime} 07^{\prime \prime} \text {, Nicholas } \\
\text { County, on right bank upstream from } \\
\text { culvert on U. S. Highway } 19,80 \mathrm{ft} \\
\text { upstream from unnamed tributary, } 4.5 \\
\text { miles north of Nallen. Elevation of gage } \\
\text { is } 1,830 \mathrm{ft} \text { above sea level. }\end{array}$ & 2.78 & $1972-76$ \\
\hline 4 & 03198450 & $\begin{array}{l}\text { Drawdy Creek near } \\
\text { Peytona, W. Va. }\end{array}$ & $\begin{array}{l}\text { Lat } 38^{\circ} 07^{\prime} 31^{\prime \prime}, \text { long } 81^{\circ} 41^{\prime} 33^{\prime \prime}, \text { Boone } \\
\text { County, on right bank } 75 \mathrm{ft} \text { upstream } \\
\text { from bridge entrance to Drawdy } \\
\text { Cemetary, } 1.0 \mathrm{mile} \text { southwest of Peytona. } \\
\text { Elevation of gage is } 770 \mathrm{ft} \text { above sea } \\
\text { level. }\end{array}$ & 7.75 & $1970-74$ \\
\hline 5 & 03202480 & $\begin{array}{l}\text { Brier creek } \\
\text { at Fanrock, w. Va. }\end{array}$ & $\begin{array}{l}\text { Lat } 37^{\circ} 33^{\prime} 50^{\prime \prime} \text {, long } 81^{\circ} 39^{\prime} 16^{\prime \prime} \text {, Wyoming } \\
\text { County, on right bank on secondary } \\
\text { State Route } 14,0.3 \mathrm{mile} \text { south of } \\
\text { Fanrock, and } 0.3 \mathrm{mile} \text { upstream from } \\
\text { mouth. Elevation of gage is } 1,220 \mathrm{ft} \\
\text { above sea level. }\end{array}$ & 7.20 & $1971-73$ \\
\hline
\end{tabular}

inches in the higher elevations near Webster Springs to 40 inches in the lower elevations in the western and southern parts of the State (fig. 3).

Prevailing westerly winds and elevation differences cause marked variations in precipitation and temperature between streamflow gaging stations in the higher mountainous areas in the east (sites 1,2, and 3) and streamflow gaging stations in hilly plateau lands in the west and south (sites 4 and 5). Regionally, moist air that flows up the western slopes of the mountains is cooled and condenses to precipitation; precipitation generally is greater in the higher areas of the State. A well-defined rain shadow is present east of the high elevations, because much of the moisture precipitates before the air reaches the eastern flank of the mountains.

Precipitation is somewhat evenly distributed throughout the year, although most falls in the summer and least in the fall. Monthly rainfall at selected sites is shown in figure 3.

Annual snowfall varies widely among the study basins. Basins in the higher mountainous areas (sites 1, 2, and 3) may receive five to seven times more snowfall than basins in the lower elevations (sites 4 and 5). At Charleston, snowfall averages about 24 inches annually, whereas near Webster Springs, snowfall averages about 200 inches annually. Most snowfalls are followed by warm periods; widescale spring melt of an accumulated snowfall rarely occurs.

The mean annual temperature ranges from about $56{ }^{\circ} \mathrm{F}$ in the hilly plateau lands to about $48^{\circ} \mathrm{F}$ in the higher mountainous areas. The minimum, mean, and maximum monthly temperatures at selected rainfall stations are shown in figure 3.

\section{Soils}

The soils in Horsecamp Run, Gilmer Run, and Collison Creek basins are classified predominantly as shallow to moderately deep silt loam and stony silt loam soils. The soils are moderately well to well drained, moderate to rapidly moderate in permeability ( 0.6 to 6.0 inches per hour), and low to moderate in available moisture capacity ( 0.06 to 0.12 inches per inch). Depth to bedrock ranges from 10 to 40 inches. 


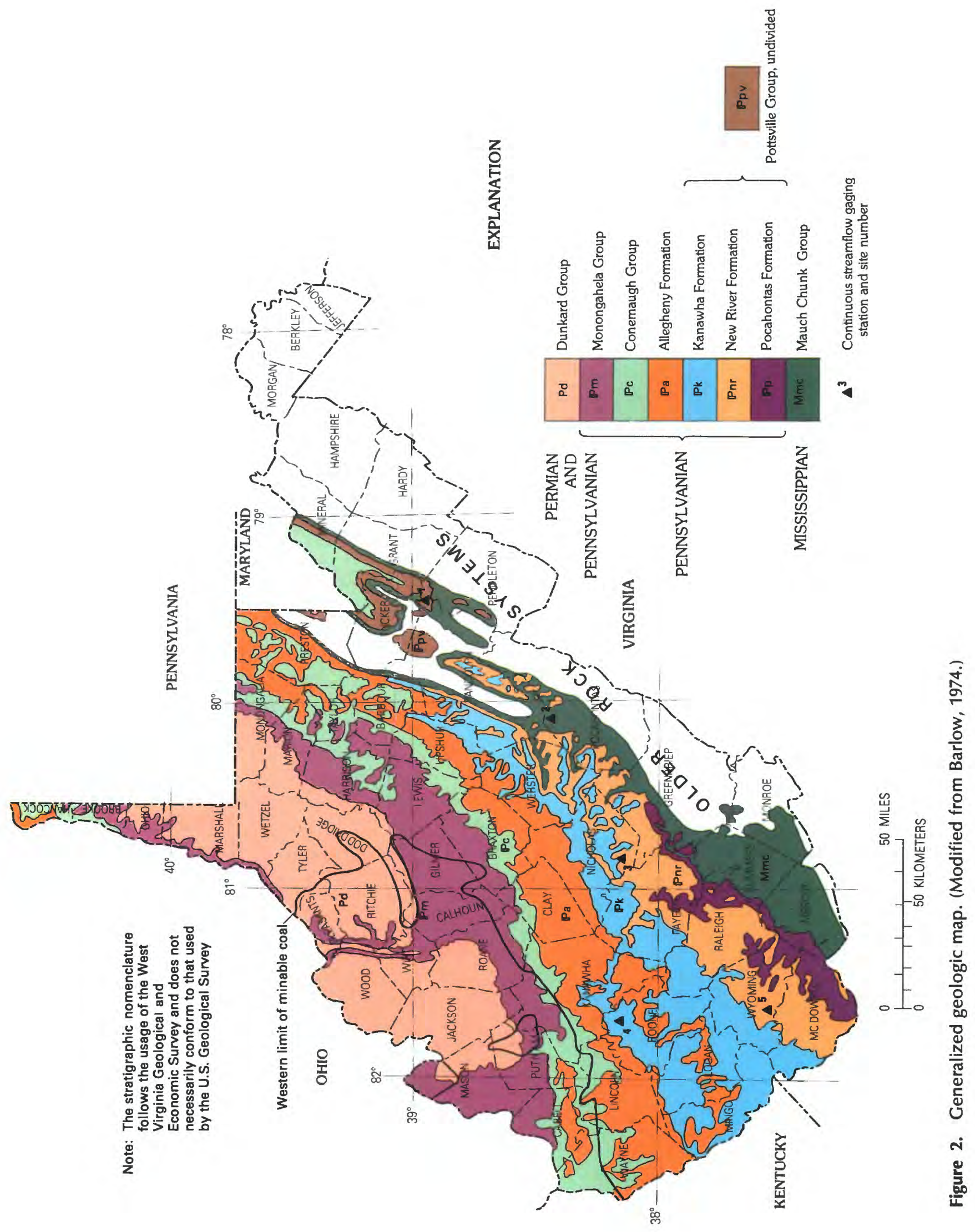



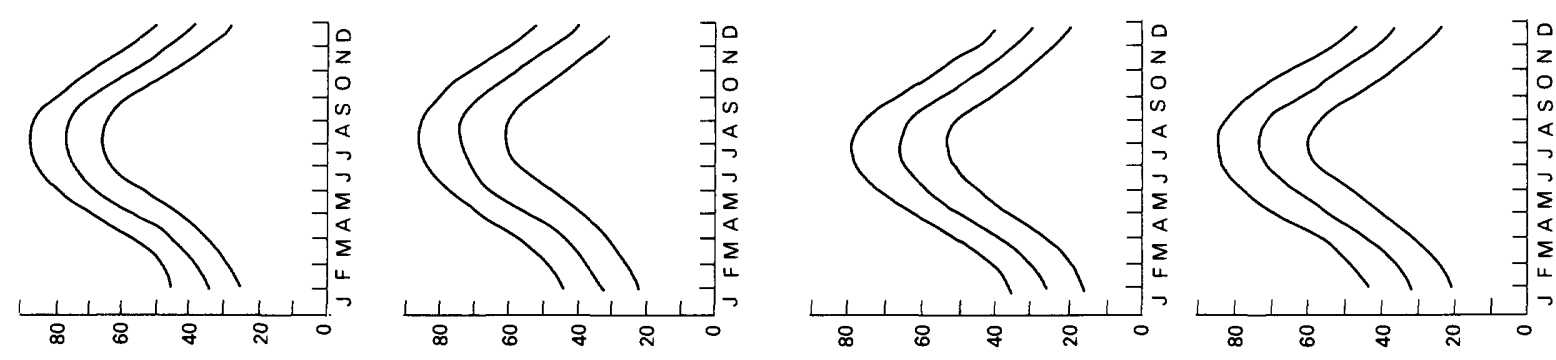

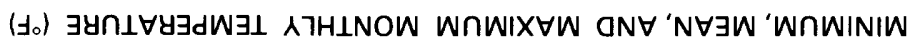
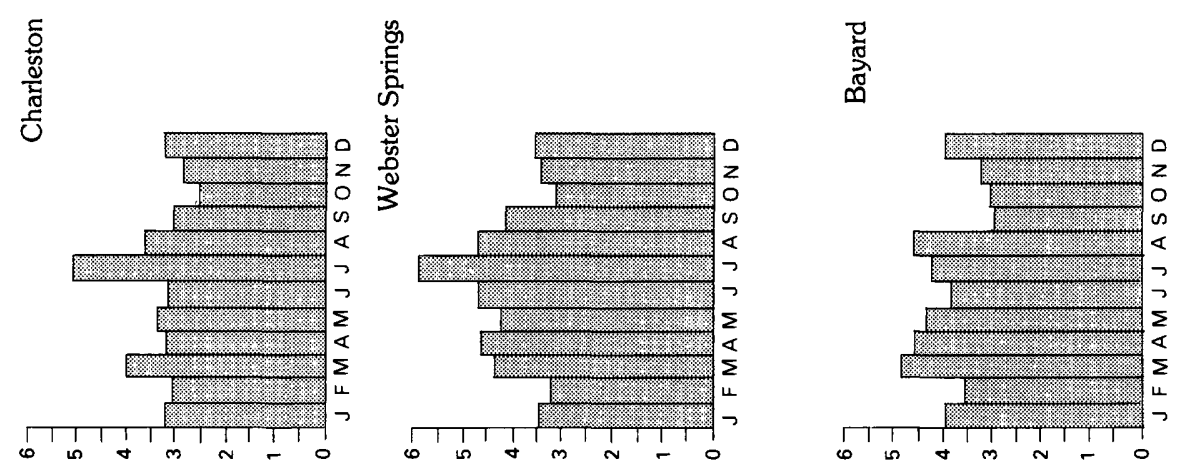

귱

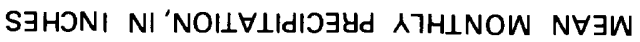
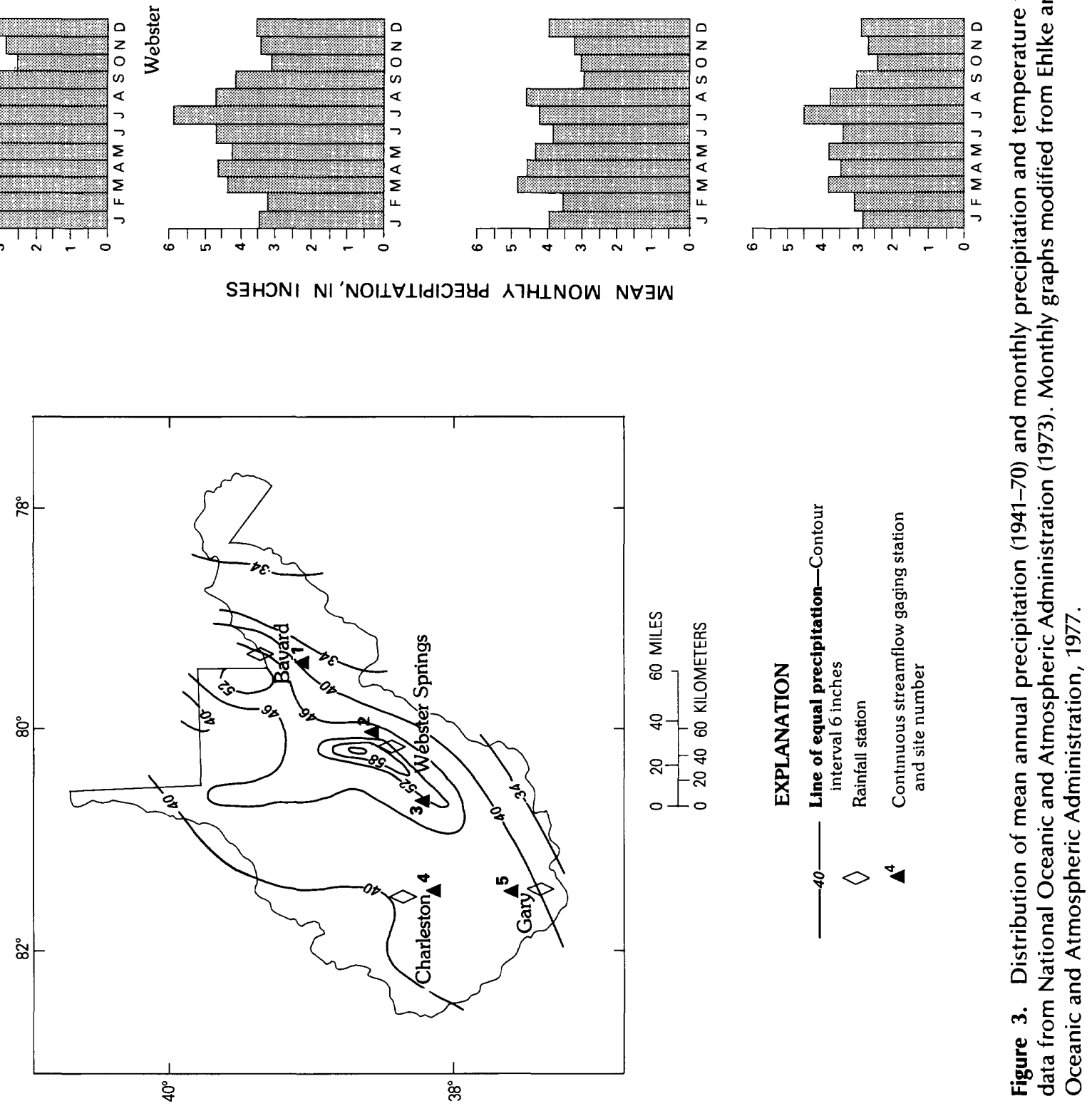
Table 2. Summary of major land uses

[In square miles; numbers in parentheses are percentages of total basin drainage area]

\begin{tabular}{llccccc}
\hline Basin & $\begin{array}{l}\text { Forest } \\
\text { cover }\end{array}$ & $\begin{array}{l}\text { Agriculture } \\
\text { or pasture }\end{array}$ & $\begin{array}{c}\text { Urban } \\
\text { land }\end{array}$ & $\begin{array}{c}\text { Surface } \\
\text { mines }\end{array}$ & $\begin{array}{c}\text { Underground } \\
\text { mine }\end{array}$ \\
\hline Horsecamp Run & $3.05(46)$ & $3.49(53)$ & $0.03(1)$ & 0 & 0 \\
Gilmer Run & $1.02(56)$ & $.77(43)$ & $.01(1)$ & 0 & 0 \\
Collison Creek & $2.13(77)$ & $.61(22)$ & $.04(1)$ & 0 & 0 \\
Drawdy Creek & $6.44(83)$ & $.30(4)$ & $.31(4)$ & $.70(9)$ & $2.00(26)$ \\
Brier Creek & $6.50(90)$ & $.45(6)$ & $.12(2)$ & $.13(2)$ & $1.44(20)$ \\
\hline
\end{tabular}

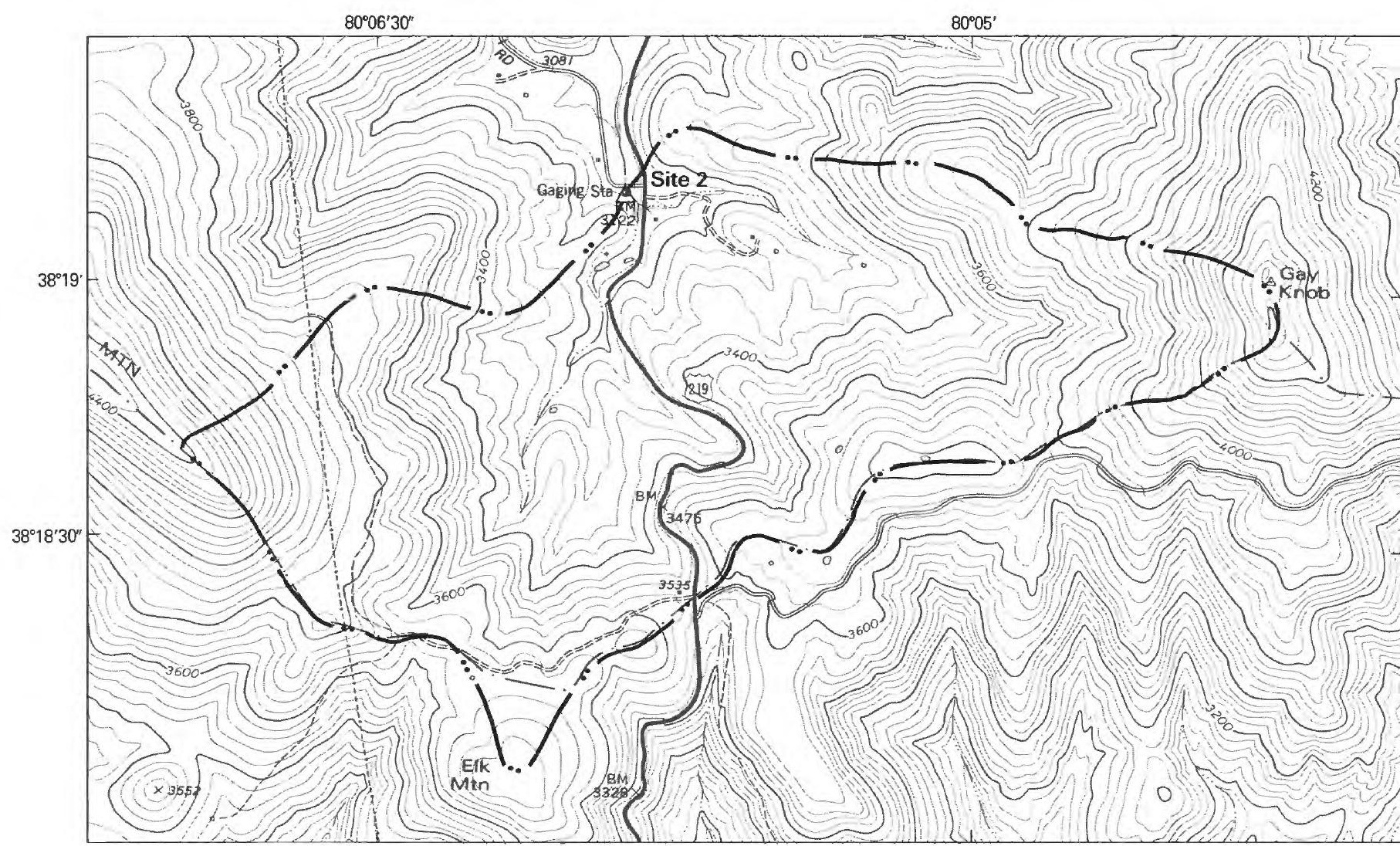

Base from U.S. Geological

Survey, Edray 1:24,000,

1977

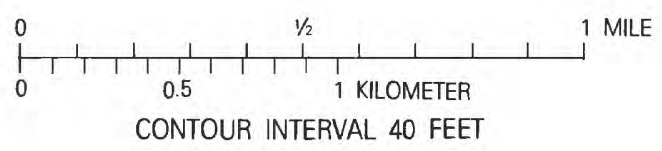

\section{EXPLANATION}

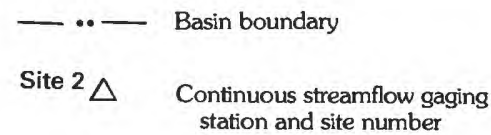

Figure 5. Physical features in Gilmer Run basin. 


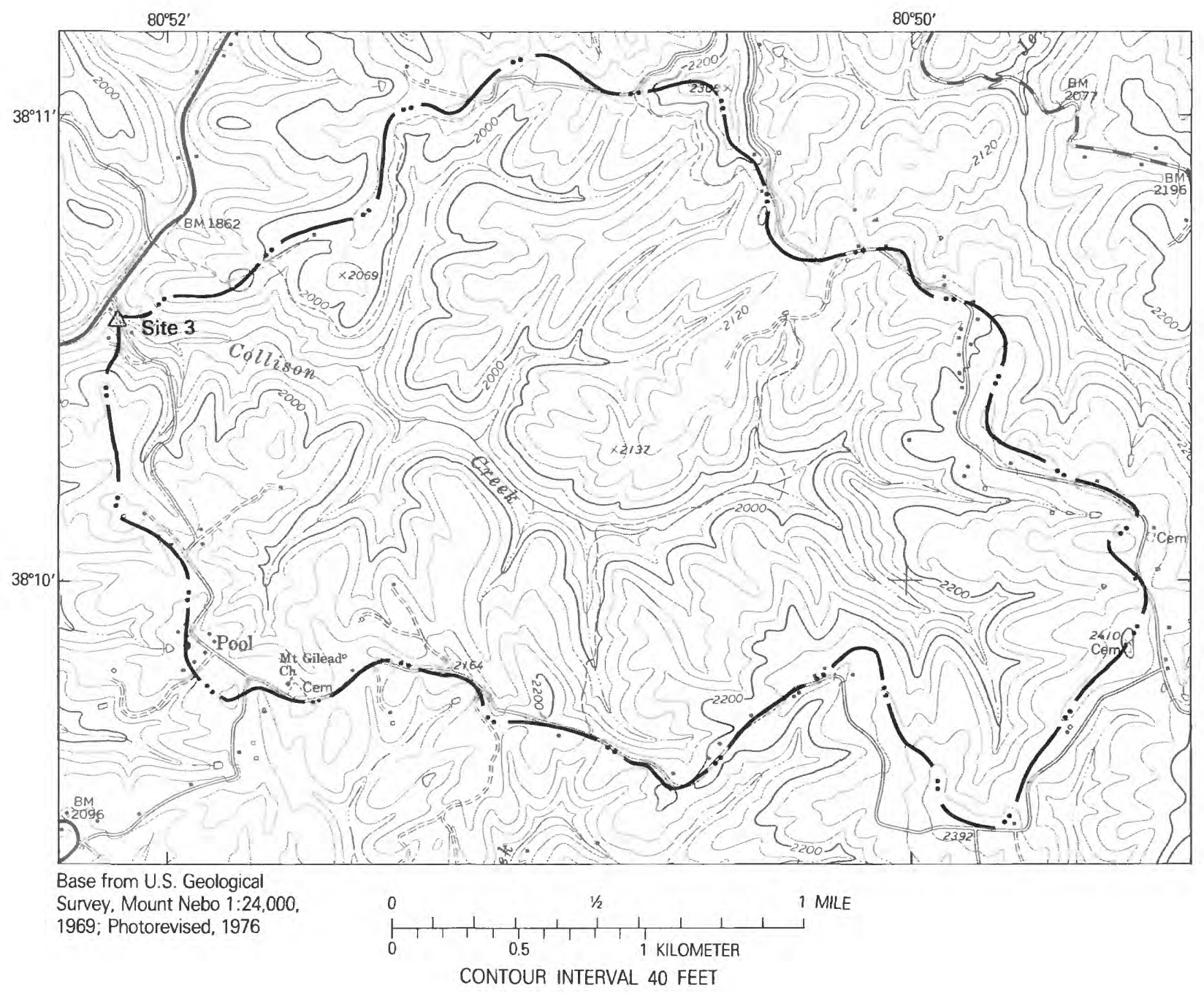

EXPLANATION

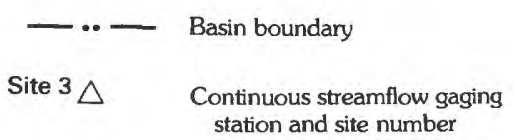

Figure 6. Physical features in Collison Creek basin.

Because of the steep terrain and generally narrow hilltops, most people in the basins live in urban areas along narrow valley floors. Urban areas, which include residential, commercial, and industrial areas, constitute from less than 1 percent of the land in Gilmer Run basin to 4 percent in Drawdy Creek basin.

Coal mining is the major land-use activity in Drawdy Creek and Brier Creek basins. The mining consists of active and inactive surface and underground mines and is typical of mining activities in most small basins in the coal areas of the State. The location of mined areas and the progression of mining in Drawdy Creek and Brier Creek basins are shown in figures 7 and 8.
Approximately 9 percent of Drawdy Creek basin has been contour strip mined and 26 percent deep mined above the elevation of the basin's major streams. The No. 2 Gas, Cedar Grove, and No. 5 Block coal seams, which range from 3.0 to 6.0 feet in thickness, are the principal beds of coal mined in the basin. Activity in some of the underground mines and surface mines ceased prior to 1970 (fig. 7). The underground mines in the southern part of the basin, however, were active during the study period. Some surface mines in the basin also were active during the study period.

About 2 percent of Brier Creek basin has been contour strip mined and 20 percent deep mined above the elevation of the basin's major streams (fig. 8). The Sewell 


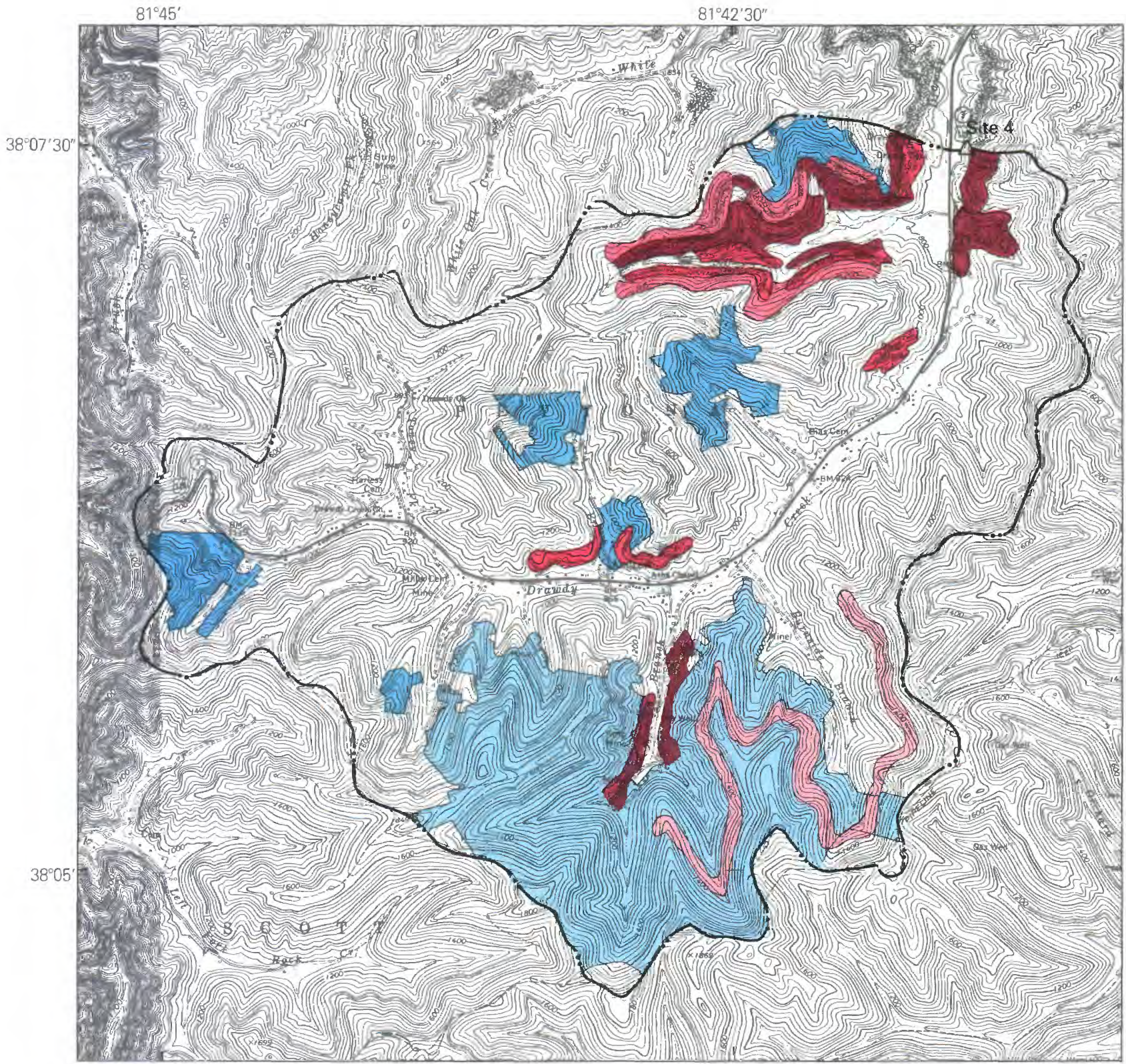

Base from U.S. Geological Survey. Williams Mountain 1:24,000, 1976: Racine

1:24,000, 1976; Madison

$1: 24,000,1976$

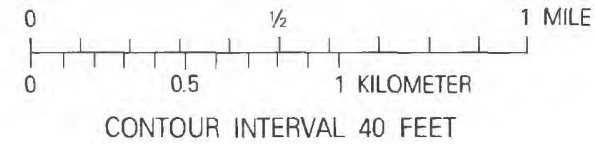

\section{EXPLANATION}
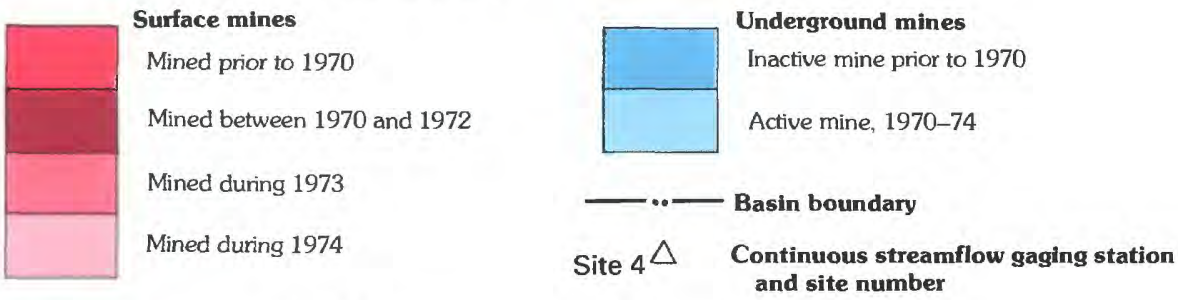

Figure 7. Coal-mined areas in Drawdy Creek basin. 
and Red Ash coal seams, which range from 2.5 to 4.0 feet in thickness, are the principal seams mined in the basin. Surface mining in Brier Creek basin was smaller in scale and more dispersed than in Drawdy Creek basin. Underground mines near the center of the basin were actively mined during the study period, whereas those along the southern and eastern boundaries of the basin were mined out and abandoned prior to 1971 .

\section{Effects of Coal Mining on the Hydrologic System}

Surface and underground coal mining significantly affects the water resources of an area. Some of these effects include flooding, diversion of drainage, and low-flow augmentation. Depending on the methods of mining, the topography of the mined areas, and mine-reclamation measures, surface mining may or may not promote flooding. For example, the clearing of land during contour surface mining may increase the amount of surface runoff and, thus, the potential for flooding. However, contour surface mines also may intercept surface runoff and alter ground-water recharge patterns.

The strip benches or terraces of contour mines usually slope inward toward the strip high wall (fig. 9) and drain water to low areas along the wall, where the water may be ponded or conducted to an outlet from the terrace instead of running off directly to adjacent streams (Ward and Wilmoth, 1968). The ponding may temporarily impede surface runoff and, thus, increase the opportunity for ground-water recharge (fig. 9). In many cases, precipitation collected on the graded strip terraces may flow into abandoned, partly filled underground-mine openings or auger holes on the hillsides, or it may be diverted along the terraces into adjacent basins. Additionally, the placement of spoil materials along the terrace may create spoil aquifers that can store large volumes of water. The water in the spoil or in ponds on the strip terraces may be a source of recharge to the ground-water system and a source of base flow to nearby streams. In some cases, the overall effect of contour surface mining may be to reduce peak flows and to increase base flows in the basin (Hobba, 1981; Borchers and others, in press).

Underground mines may affect rates of ground-water recharge and alter the flow path of ground water. Mine-roof collapse in underground mines commonly causes the overlying rocks to settle and fracture (fig. 9). This settling may cause subsidence and the vertical propagation of extensive fractures to the land surface. The fractures increase rock permeability and permit greater percolation of precipitation (recharge) to the ground-water reservoir; they also promote drainage of ground water downward to the mines, where the water may move laterally to streams by gravity drainage or by active mine pumping (Hobba, 1981). The presence of surface-subsided areas with open fractures over deep-mined parts of Drawdy Creek basin was reported by local residents.

Commonly, sealed and abandoned underground mines store large volumes of water which seeps through mine openings and increases base flow in adjacent streams. Drift mines on hills may slope upward or downward away from the local surface drainage, or they may be horizontal. Where the dip of the rocks is away from the local surface drainage, recharge precipitation, surface runoff, and ground water in a basin may be intercepted by subsidence fractures and diverted to underground mines that drain into another drainage basin (Ward and Wilmoth, 1968). In active underground mines, pumps commonly are used to remove excess water in the mines.

An example of the combined effects of underground and surface mining on peak flows and base flows in small basins (Borchers and others, in press) is illustrated in figure 10 , in which runoff in five small and adjacent basins near Brier Creek basin is compared. The peak flows were in response to a storm on November 2, 1979, when measured storm precipitation in the basins ranged from 1.01 inches (Allen Creek) to 1.28 inches (Marsh Fork). Examination of figure 10 indicates that the highest measured peak flow in the basins occurred in Marsh Fork - an unmined basin; the lowest measured peak flow occurred in Allen Creek-the basin with the greatest amount of mining ( 20 percent of basin drainage area surface mined and 51 percent underground mined). Six days after the peak flows, base flows were lowest at Marsh Fork and greatest at Milam Fork-a basin with 1 percent of the basin drainage area surface mined and 37 percent underground mined. Pumpage to remove excess water in underground mines appears as small bumps on the Still Run basin hydrograph.

Streamflow measurements at numerous synoptic sites in Drawdy Creek and Brier Creek basins (figs. 11, 12) during February and March 1983 show the effects of coal mining on the quantity and distribution of base flow in unmined and mined areas in each basin. Synoptic measurements of streamflow in the unmined basins-Horsecamp Run, Gilmer Run, and Collison Creek-were not made because no appreciable land-use activity sufficient enough to affect the quantity and distribution of base flow in the basins was observed.

\section{Drawdy Creek}

Streamflow measurements made during medium- to high-base-flow conditions at numerous sites in Drawdy Creek basin (site 4) indicate that mining activity has altered the natural hydrologic system of the basin (fig. 11). As shown in figure 11 , subbasins with the highest and lowest base-flow yield generally contain coal mines. 


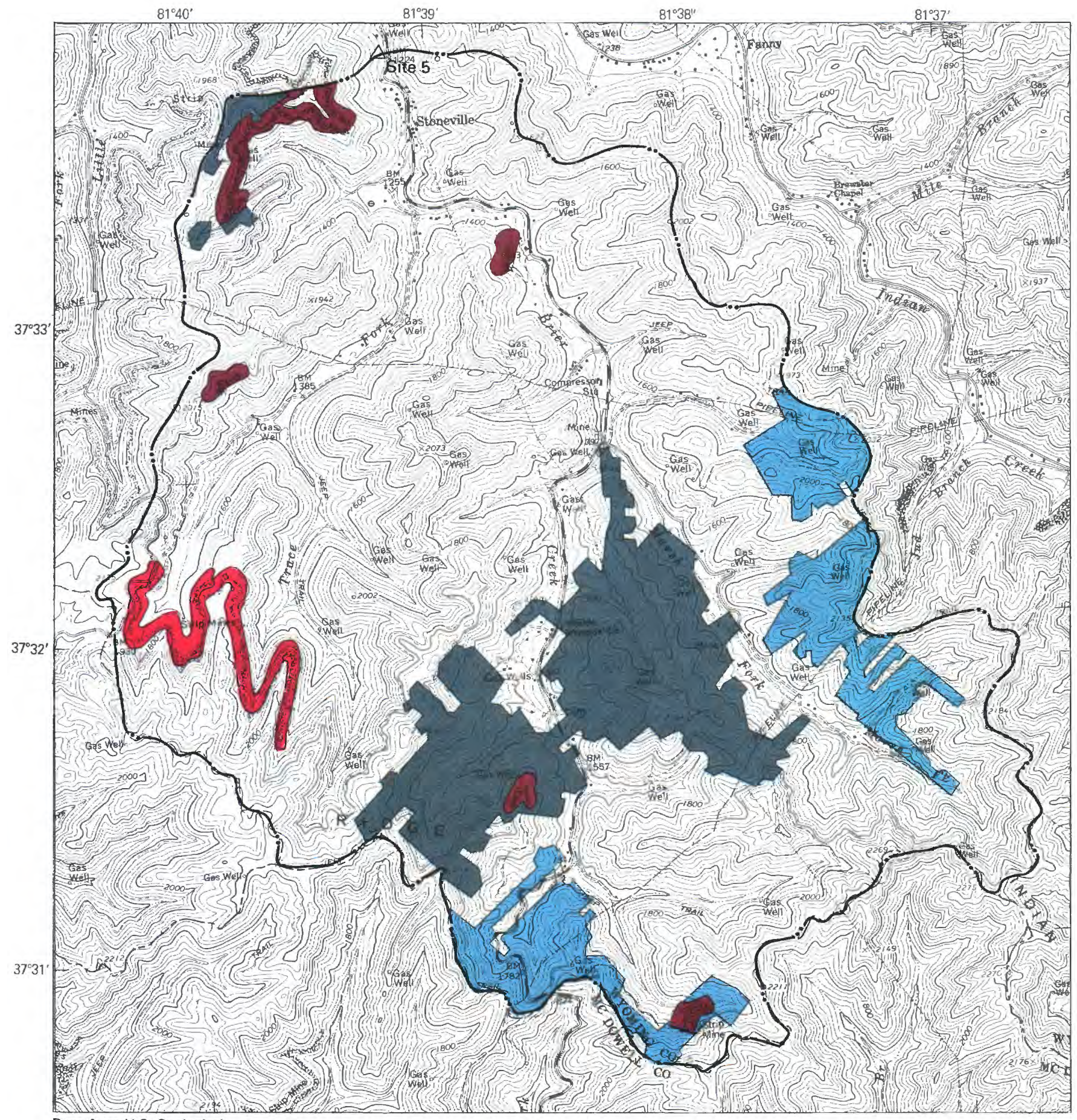

Base from U.S. Geological

Survey, Baileys ville 1:24,000,

1976; Pineville 1:24,000, 1976

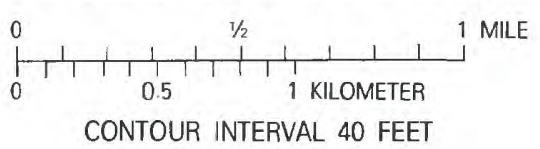

CONTOUR INTERVAL 40 FEET

\section{EXPLANATION}

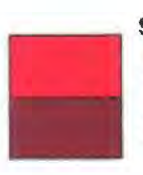

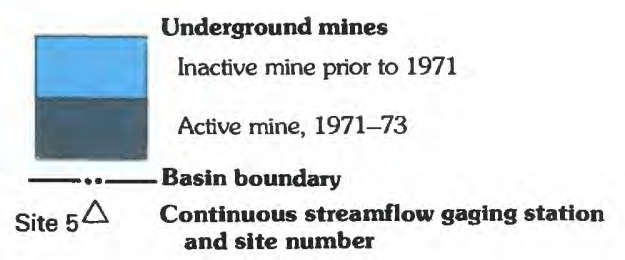




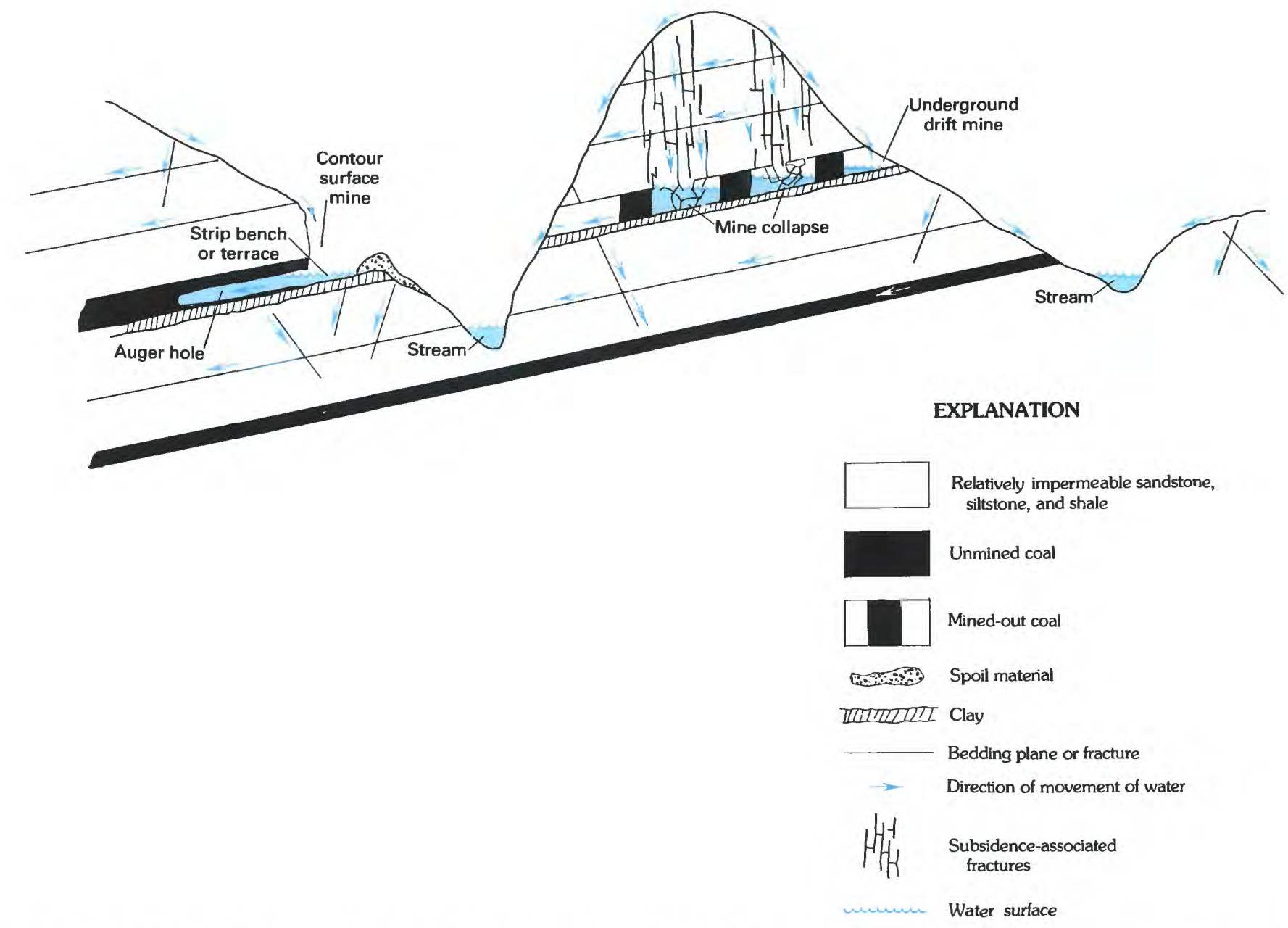

Figure 9. Relation between dip of coal, location and condition of abandoned underground mines, and movement of water.

Parts of the basin that are stratigraphically downdip and beneath the elevation of the mined beds of coal generally have the highest base-flow yields. In contrast, the lowest base-flow-yield areas generally are underlain by underground coal mines and are updip from areas of high yield. Some areas of high and low base-flow yield are adjacent to each other but are separated by basin divides (see Morgan Branch and adjacent subbasins to the west in fig. 11). The coal beds in the ridges separating these areas have been deep mined, and in some outcrop areas the

Figure 8. Coal-mined areas in Brier Creek basin.

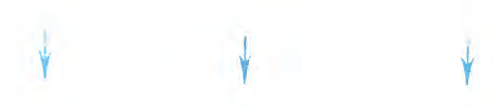




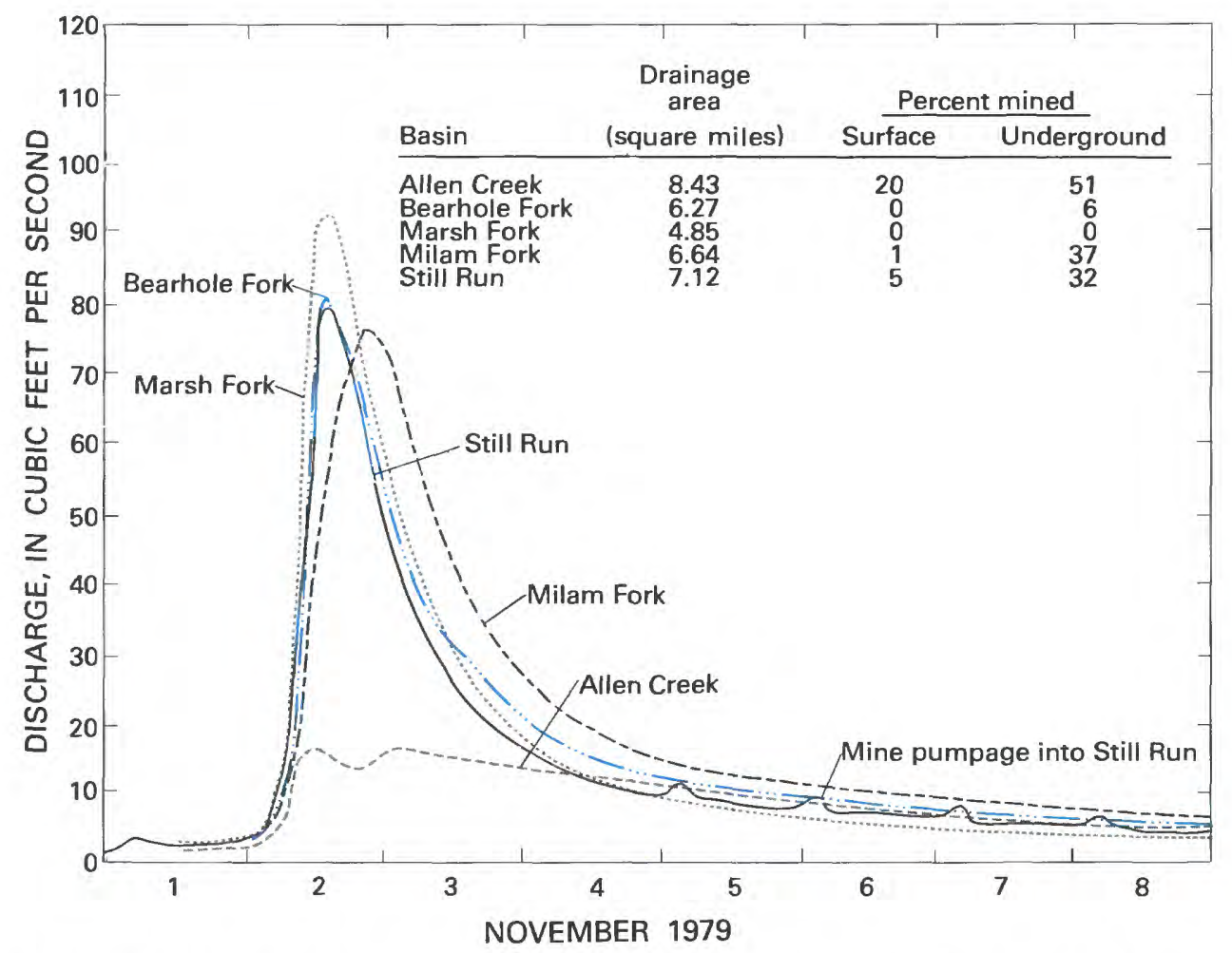

Figure 10. Basin peak-flow response to storm of November 1979. (Modified from Borchers and others, in press.)

\section{Brier Creek}

Areas of high and low base-flow yield in streams in Brier Creek basin similarly occur mainly in or near extensively mined areas (fig. 12).

The areas having high base-flow yields also generally are stratigraphically downdip and beneath the elevation of the mined beds of coal. Areas having the lowest yields generally are underlain by underground mines. The streamflow measurements made in Drawdy Creek and Brier Creek basins were not sufficient to determine the contribution of individual surface or underground mines to total base flow in the basins.

\section{SIMULATION OF RAINFALL-RUNOFF RESPONSE IN MINED AND UNMINED WATERSHEDS IN COAL AREAS}

\section{Description of Model}

The U.S. Geological Survey's Precipitation-Runoff Modeling System used in this study is documented in the user's manual (Leavesley and others, 1983). It was developed to provide deterministic physical-process modeling capabilities for estimating the effects of climate and land use on the hydrologic system of small basins. The model is designed to function as either a lumped-parameter or distributed-parameter type of model and will simulate both daily mean flow and stormflow. For this study, the data required to drive the model are precipitation, air temperature, and pan-evaporation data.

\section{Model Characteristics}

The distributed-parameter modeling capability is provided by partitioning a basin into hydrologic-response units (HRU's) on the basis of measurable climatic, physiographic, vegetative, land-use, and soil features. Partitioning permits accounting for temporal and spatial variations of basin physical and hydrologic characteristics. Each HRU is considered homogeneous with respect to these characteristics and its hydrologic response. The sum of the responses of all HRU's, weighted by unit area, produces the total system response, which, in this report, is daily mean streamflow.

The watershed system is described as a series of linear or nonlinear reservoirs, with outputs combined to produce the total system response (fig. 13). Water in the upper soil zone is increased by infiltration of rainfall and snowmelt and is depleted by evapotranspiration. Average rooting depth of the predominant vegetation that covers the soil surface defines the depth of this zone. 


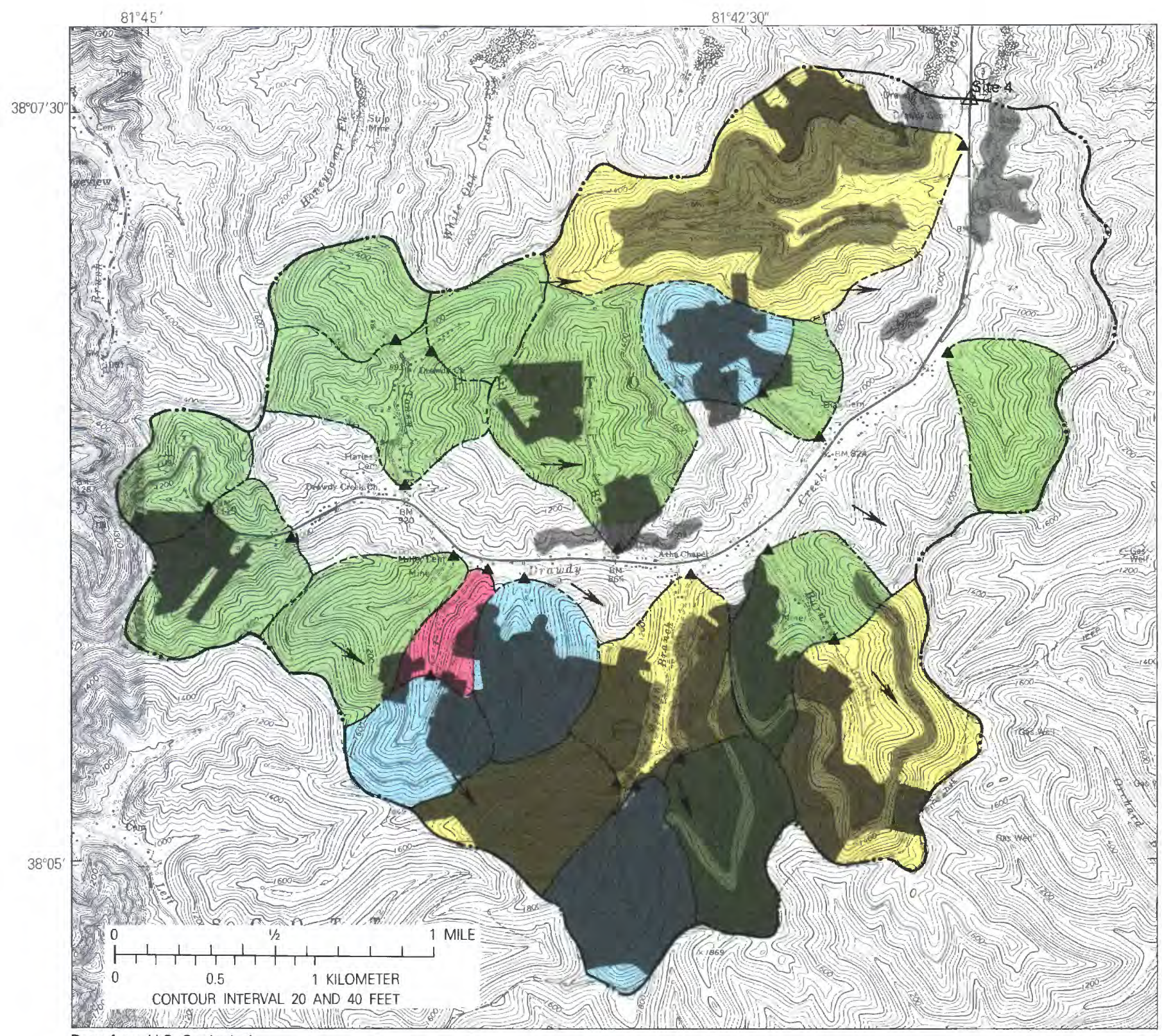

Base from U.S. Geological

Survey, Williams Mountain

1:24,000, 1976, Racine

1:24.000. 1976; Madison

\section{EXPLANATION}

$1: 24,000$

Base-flow yield range, in

cubic feet per second

per square mile

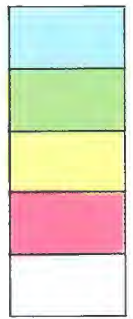

$0-1.00$

$>1.00-1.75$

$>1.75-2.50$

$>2.50$

Undetermined

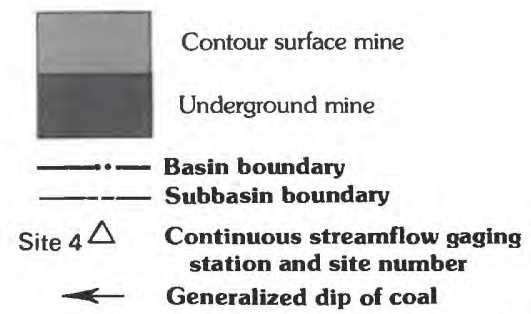

A Synoptic streamflow measuring site

Figure 11. Base-flow yield in Drawdy Creek basin, February 1983. 


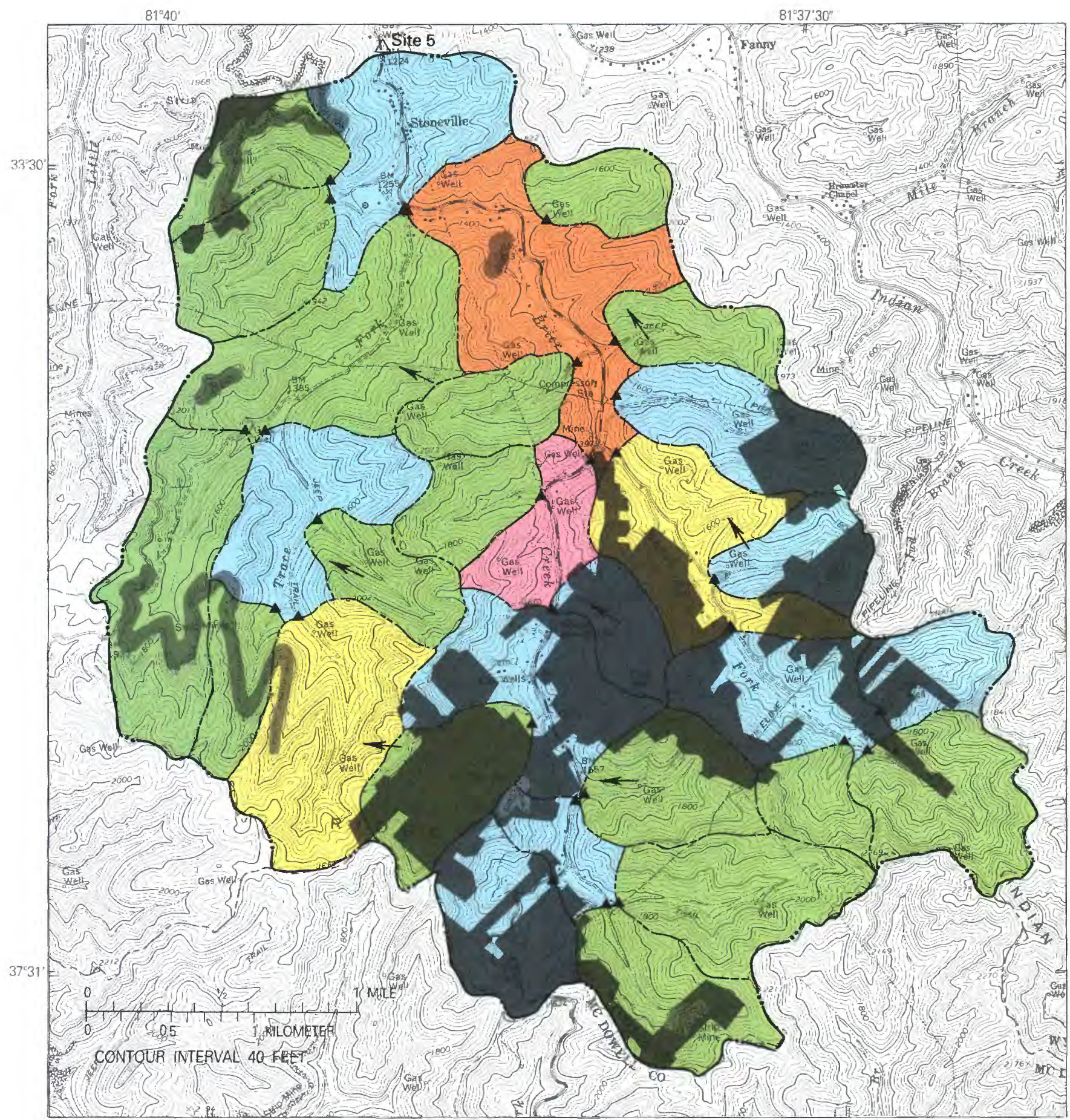

Base from U.S. Geological

Survey, Baileysville 1:24,000,

1976; Pineville 1:24,000, 1976

\section{EXPLANATION}

Base-flow yield range, in cubic feet per second per square mile

$0-0.50$

$>0.50-1.00$

$>1.00-1.50$

$>1.50-3.00$

$>3.00$

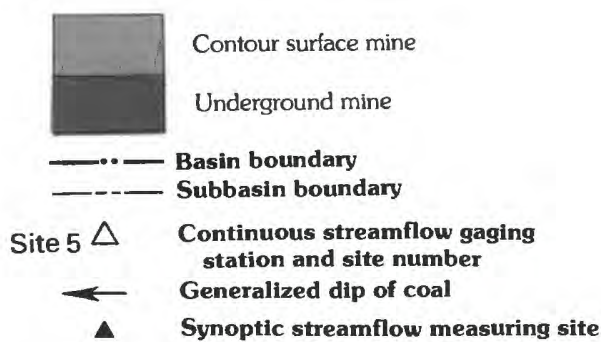




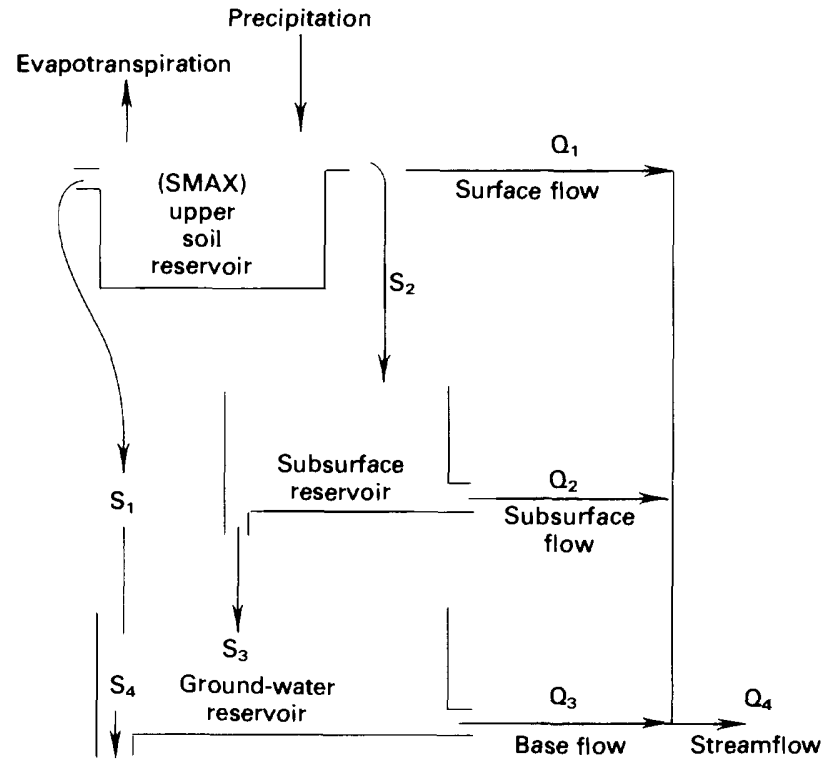

Figure 13. Schematic diagram of the watershed model. (Modified from Weeks and others, 1974.)

Surface runoff, $Q_{1}$, occurs after the upper soil zone reaches field-moisture capacity and also when rainfall exceeds the maximum infiltration rate. The volume of rain that becomes $Q_{1}$ is computed using a variable contributingarea concept described by Hewlett and Nutter (1970). Seepage to the ground-water reservoir, $S_{1}$, first occurs only after the upper soil zone reaches field-moisture capacity; it is assumed to have a maximum daily limit. Excess infiltration, available after $S_{1}$ is satisfied, then becomes recharge to the subsurface reservoir, $S_{2}$. The subsurface reservoir, representing shallow ground-water zones, is the source of all subsurface flow, $\mathrm{Q}_{2}$, that moves through the soil from points of infiltration to some point of discharge above the water table or into the ground-water reservoir, $S_{3}$. Subsurface flow moves rapidly to stream channels and supports the recession of snowmelt and stormflow hydrographs.

Recharge to the ground-water reservoir can occur from the upper soil zone and from the subsurface reservoir. Seepage from the subsurface reservoir to the ground-water reservoir is a function of a daily seepage rate and the amount of water in the subsurface reservoir. The groundwater reservoir is assumed to be a linear reservoir and is the source of all long-term base flow or ground-water discharge, $\mathrm{Q}_{3}$, to streams. Movement of water through the ground-water system to points beyond the area of interest (ground-water sink) is by seepage, $\mathrm{S}_{4}$, which is a function of storage in the ground-water reservoir. The sum of outputs $\mathrm{Q}_{1}, \mathrm{Q}_{2}$, and $\mathrm{Q}_{3}$ produces the total daily streamflow, $\mathrm{Q}_{4}$.

Figure 12. Base-flow yield in Brier Creek basin, March 1983.
The model structure and operation flowchart shown in figure 14 identifies those model components that attempt to reproduce the physical processes of the hydrologic cycle. The model structure is divided into climatic, land-phase, and snow components. The climatic component accepts and adjusts input data to better define the climate in each HRU. Variations in climate that result from changes in physical characteristics, vegetation cover, and time are adjusted for each HRU on the basis of each HRU's median elevation, slope, aspect, and vegetation.

The land-phase components simulate the effects of vegetation, soil, and geology of an HRU. These include interception, infiltration, evapotranspiration, soil-water accounting, surface runoff, subsurface flow, and groundwater discharge.

The snow component simulates the initiation, accumulation, and depletion of the snowpack on each HRU. The snowpack is maintained and modified both on a waterequivalent basis and as a dynamic heat reservoir. Selected physical characteristics of delineated hydrologic-response units for each basin are summarized in table 3 .

\section{Data Requirements}

Daily precipitation, air temperature, and panevaporation data are needed to drive the model in a daily-flow mode. Where pan-evaporation data are not available, they can be estimated by the modeling system using daily solar radiation data or minimum and maximum air-temperature data.

Precipitation data, recorded at 15 -minute intervals, were obtained from a recording rain gage located at the outflow continuous streamflow gaging station in each of the study basins (sites 1-5). Daily maximum and minimum air-temperature data were obtained from National Weather Service (NWS) rainfall stations usually located within 10 miles of the basins. Daily values of pan-evaporation data also were obtained from the NWS, which maintains a climatic station at Bluestone Reservoir approximately 35 miles east of Brier Creek basin (site 5).

Basin characteristics, such as land slope, aspect, and elevation, were obtained from U.S. Geological Survey topographic maps at a scale of 1:24,000 (figs. 4-8). The types, extent, and cover density of the predominant vegetation in the study basins were determined by visual observation, topographic maps (scale 1:24,000), and land use-land cover maps (U.S. Geological Survey, 1979, 1981) at a scale of 1:250,000.

Soils data were compiled from a statewide, general soil-association map (U.S. Soil Conservation Service, 1979). The map shows the soil associations in the basins. Because the general soils map did not show the spatial extent of the major individual soil series within the soil 


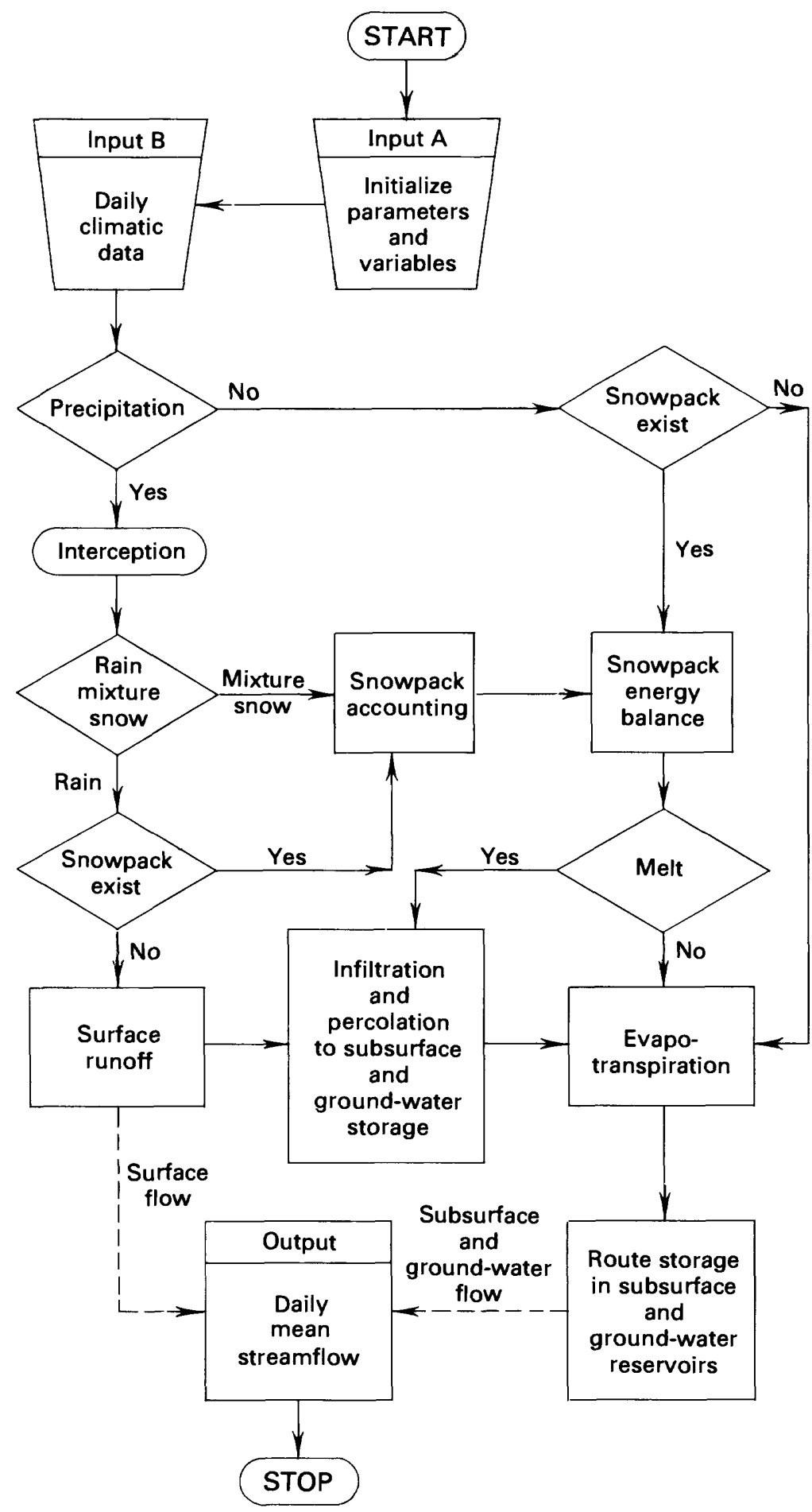

Figure 14. Flowchart of the digital watershed model. (From Weeks and others, 1974.)

associations, it was assumed that each soil series is uniformly distributed and present in equal proportion within a soil association.

Data such as soil type, texture, water-holding capacity, rooting depth, and depth to bedrock were obtained from
U.S. Soil Conservation Service county soil-survey reports (Latimer, 1915; U.S. Soil Conservation Service, 1967, $1972,1975)$ available for adjacent and nearby areas.

Hydrologic-data requirements consist mainly of continuous streamflow records measured at the outflow gaging 
Table 3. Summary of selected characteristics of the hydrologic-response units (HRU's) used in the model

\begin{tabular}{|c|c|c|c|c|c|c|}
\hline $\begin{array}{c}\text { HRU } \\
\text { number }\end{array}$ & $\begin{array}{c}\text { Area } \\
\text { (acres) }\end{array}$ & $\begin{array}{l}\text { Aspect } \\
\text { (compass } \\
\text { direction) }\end{array}$ & $\begin{array}{l}\text { Mean } \\
\text { overland } \\
\text { slope } \\
\text { (percent) }\end{array}$ & $\begin{array}{l}\text { Median } \\
\text { elevation1/ } \\
\text { (feet) }\end{array}$ & $\begin{array}{c}\text { Major } \\
\text { vegetation } 2 /\end{array}$ & Soils \\
\hline \multicolumn{7}{|c|}{ Horsecamp Run Basin } \\
\hline 1 & 1,420 & $\mathrm{NE}$ & 26 & 3,180 & Grass/Forest & silt loam \\
\hline 2 & 1,153 & W & 22 & 3,470 & Grass/Forest & silt loam \\
\hline 3 & 1,632 & SW & 32 & 3,450 & Grass/Forest & silt loam \\
\hline \multicolumn{7}{|c|}{ Gilmer Run Basin } \\
\hline 1 & 467 & NNE & 19 & 3,400 & Grass & Stony silt loam \\
\hline 2 & 685 & $\mathbf{w}$ & 28 & 3,600 & Forest & Stony silt loam \\
\hline \multicolumn{7}{|c|}{ Collison Creek Basin } \\
\hline 1 & 775 & $\mathbf{N}$ & 15 & 2,040 & Forest & Stony silt loam \\
\hline 2 & 1,024 & SW & 15 & 2,090 & Forest & Stony silt loam \\
\hline \multicolumn{7}{|c|}{ Drawdy Creek Basin } \\
\hline 1 & 3,232 & $\mathrm{NE}$ & 20 & 1,140 & Forest & silt loam \\
\hline$\underline{3} / 2$ & 1,728 & SE & 16 & 1,090 & Forest/Bare & Stony silt loam \\
\hline \multicolumn{7}{|c|}{ Brier Creek Basin } \\
\hline 1 & 3,604 & NW & 34 & 1,640 & Forest & Silt loam \\
\hline $3 / 2$ & 1,005 & $\mathbf{N E}$ & 19 & 1,950 & Forest/Bare & Stony silt loam \\
\hline
\end{tabular}

1/ Datum is sea level.

$\frac{2}{3}$ Forest--Mostly deciduous hardwoods and some conifers.

3/ Hydrologic response unit (HRU) representing mined areas.

station in each basin. The streamflow data used for fitting the model to the study basins were those for the gaging stations listed in table 1 .

\section{Model Calibration and Verification}

Calibration of the model was necessary to obtain estimates of model parameters defining hydrologic properties of the watersheds. The calibrating procedure was based on 1 year of hydrologic data and consisted of fitting simulated discharge to observed daily mean discharge. A series of model runs, in which initial model parameter values were changed, was conducted to obtain a "best fit" of the model output to the observed data at each site.

The calibration process was based on a combination of trial-and-error adjustments and limited automatic optimization. The automatic-optimization procedure (Rosenbrock, 1960) used the following objective function (OF) to minimize the sums of the absolute differences between the simulated daily mean flow and the observed daily mean flow:

$$
\mathrm{OF}=\operatorname{minimum} \sum_{\mathrm{i}=1}^{\mathrm{n}}\left|\mathrm{Q}_{\mathrm{i}}-\mathrm{s}_{\mathrm{i}}\right|
$$

where

$\mathrm{Q}_{\mathrm{i}}=$ observed discharge,

$\mathrm{S}_{\mathrm{i}}=$ simulated discharge,

$\mathrm{n}=$ number of days, and

$\mathrm{i}=\mathrm{i}$ th day.

Initial estimates of land-phase model parameters, such as interception, cover density, evapotranspiration losses, and soil-moisture storage, were based on the physical characteristics (soils, vegetation, land use, and topography) of the watersheds. Model parameters affecting surface, subsurface and ground-water routing coefficients, and subsurface and ground-water storage and depletion rates were based on measured streamflow records. Model parameters affecting snowpack accumulation and snowmelt timing were based on other model applications (Leavesley, 1981). Appendix A contains a comprehensive list of parameters derived from the model calibration for each basin; 
included are the model parameter names, definitions, and values used during calibration.

Some of the more important calibrated model parameters (appendix A) found to be sensitive for predicting streamflow are SMAX, RSEP, RCB, GSNK, RCF, RCP, $\mathrm{SCN}$, and $\mathrm{SC} 1$. One of the more important parameters, SMAX, is the soil-moisture storage capacity above which soil water moves to the subsurface and ground-water reservoirs and ultimately to the stream channel (fig. 13). As SMAX increases, more water can be stored in the soil zone and is available for evapotranspiration, ET. As SMAX gets smaller, less water is available for ET losses and more water can reach the stream channel. RSEP and RCB are routing coefficients affecting the rate at which water moves from the subsurface reservoir to the ground-water reservoir, and the base-flow-recession rate, respectively. As RSEP increases, more water seeps from the subsurface reservoir into the ground-water reservoir. RCB controls the timing of ground-water contribution to base flow. As RCB increases, water from ground-water storage is discharged as base flow at a faster rate. GSNK is a routing coefficient directly affecting the rate at which water moves from the groundwater reservoir to points beyond the basin-ground-water sink. RCF and RCP are routing coefficients affecting the shape of the subsurface flow recession immediately following peak flows. SCN and $\mathrm{SCl}$ are empirical coefficients affecting the timing and amount of surface runoff during storm periods.

Hydrologic-response-unit delineations in the unmined basins were based primarily on basin physical characteristics (slope and aspect). Model components affecting the surface system (basin physical characteristics, soils, and cover density) were defined as a distributed-parameter system; model components affecting the subsurface and ground-water system (soil-moisture storage, and subsurface and ground-water routing coefficient) were defined as a lumped-parameter system. Sufficient data were not available to permit definition of the spatial variability of subsurface ground-water model parameters within the basins. Calibrated model parameter values for the three unmined basins are almost the same magnitude, and this reflects the similarity in soil types and depths, vegetation, topography, geology, and streamflow characteristics in the basins. Only one subsurface reservoir and one ground-water reservoir were used to describe the ground-water system of each basin.

Hydrologic-response-unit delineations in the mined basins were based mainly on basin physical characteristics, such as slope, aspect, and the presence of mined areas in the basins. Because of the spatial distribution of mining activity, the limited tributary runoff data within the basins, and the small areal extent of surface mining in the basins, surface- and underground-mined areas were aggregated and considered as one HRU. It was assumed that the mined areas are homogeneous with respect to climate, basin characteristics, and hydrologic response. Each mined basin was divided into two HRU's-one representing unmined areas and the other representing mined areas.

Initial estimates of model parameters that define soil-water relations in the mined areas were based on visual estimates of the distribution, composition, depths of spoil materials in the basins, and other information describing the hydraulic properties of spoil materials (Younos and Shanholtz, 1980) in nearby surface-mined areas. Model parameters that define subsurface and ground-water storage, and flow-routing coefficients in the mined areas, were based mainly on measured streamflow records at outflow gaging stations in the basins and on other information that describes ground-water and surface-water relations in small, intensively mined (underground in combination with surface) basins (Hobba, 1981).

The adequacy of the model for simulating long-term streamflow was demonstrated by simulating daily flows for substantially longer periods of record at each site. Model calibration and verification results are provided in the following section.

\section{Model Simulations}

\section{Historic Conditions}

Before the model could be considered suitable for predicting the hydrologic response to various hypothetical mining situations, it was necessary to demonstrate its ability to reasonably simulate observed responses to historic conditions. The adequacy of the model was determined during the calibration and verification process by comparing simulated streamflow and water-budget items with those observed or deduced from hydrologic observation and interpretation. Monthly and annual discharge volumes as well as graphs showing seasonal runoff distribution, hydrologic-response timing, minimum and maximum daily mean flows, recession rates, and duration of flow were compared. This section reports on comparisons of simulated and observed streamflow and water budgets for the periods of simulation.

\section{Streamflow}

The hydrographs in figures 15 through 19 illustrate model calibration results for each site. Model calibration results for unmined sites-Horsecamp Run, Gilmer Run, and Collison Creek-are based on 1972 water-year data. Observation of the hydrographs in figures $15-17$ indicates that predicted discharges at the sites generally are in agreement with observed discharges. The magnitude and timing of predicted daily maximum and recession flows, and the seasonal runoff distributions, compare favorably with observed values. 


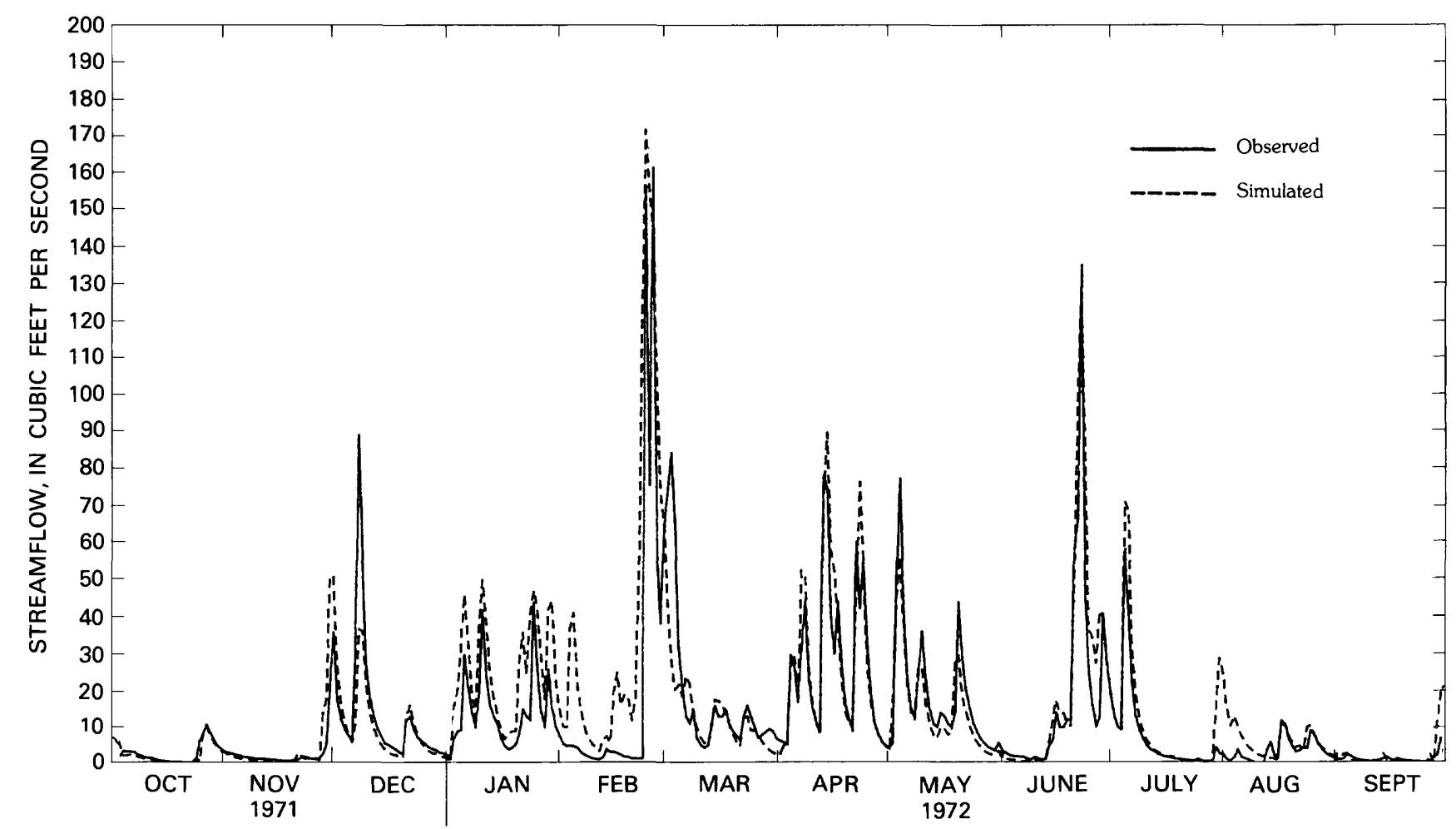

Figure 15. Observed and simulated daily mean streamflow at Horsecamp Run at Harman, October 1971-September 1972.

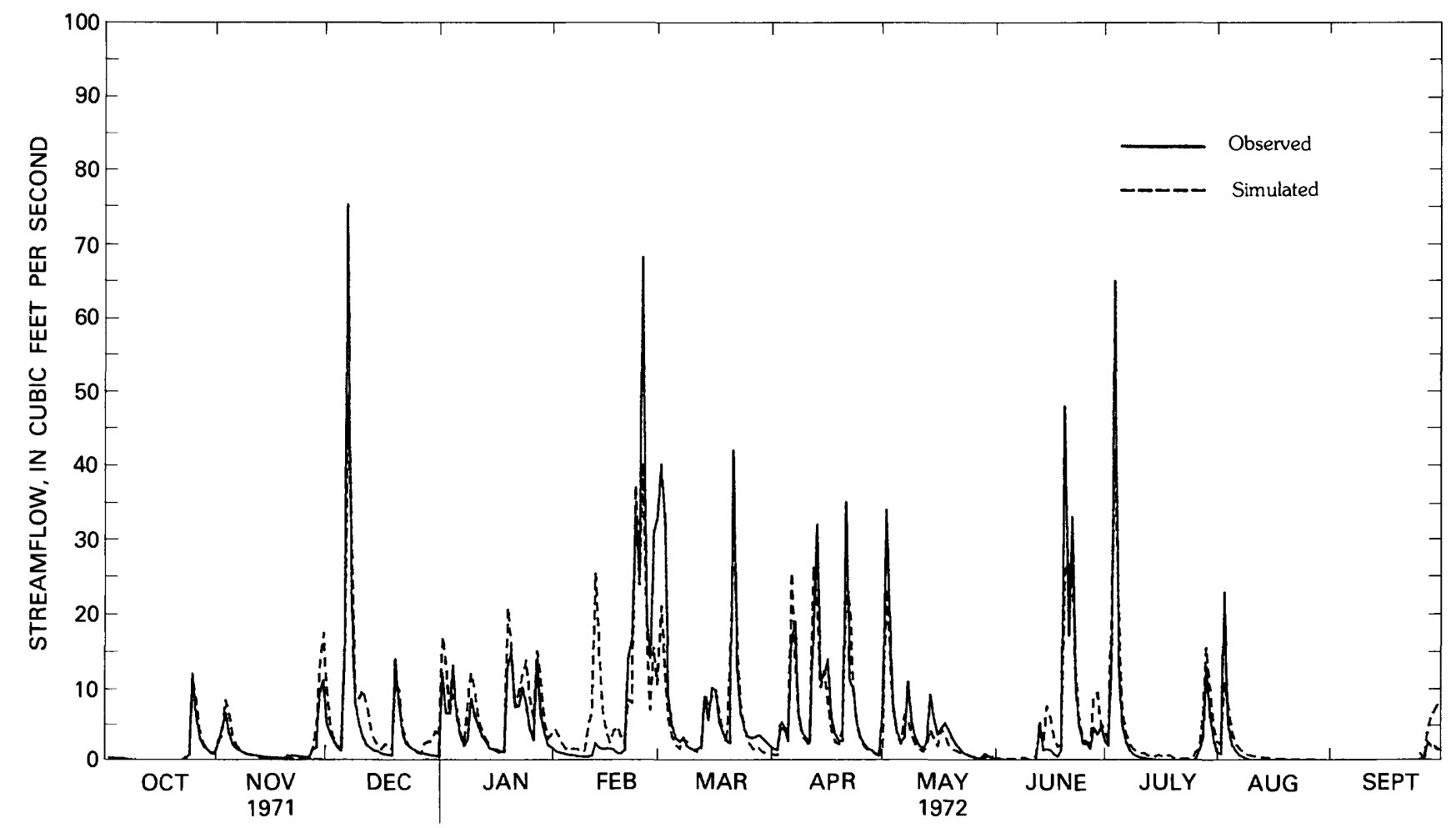

Figure 16. Observed and simulated daily mean streamflow at Gilmer Run near Marlinton, October 1971-September 1972. 


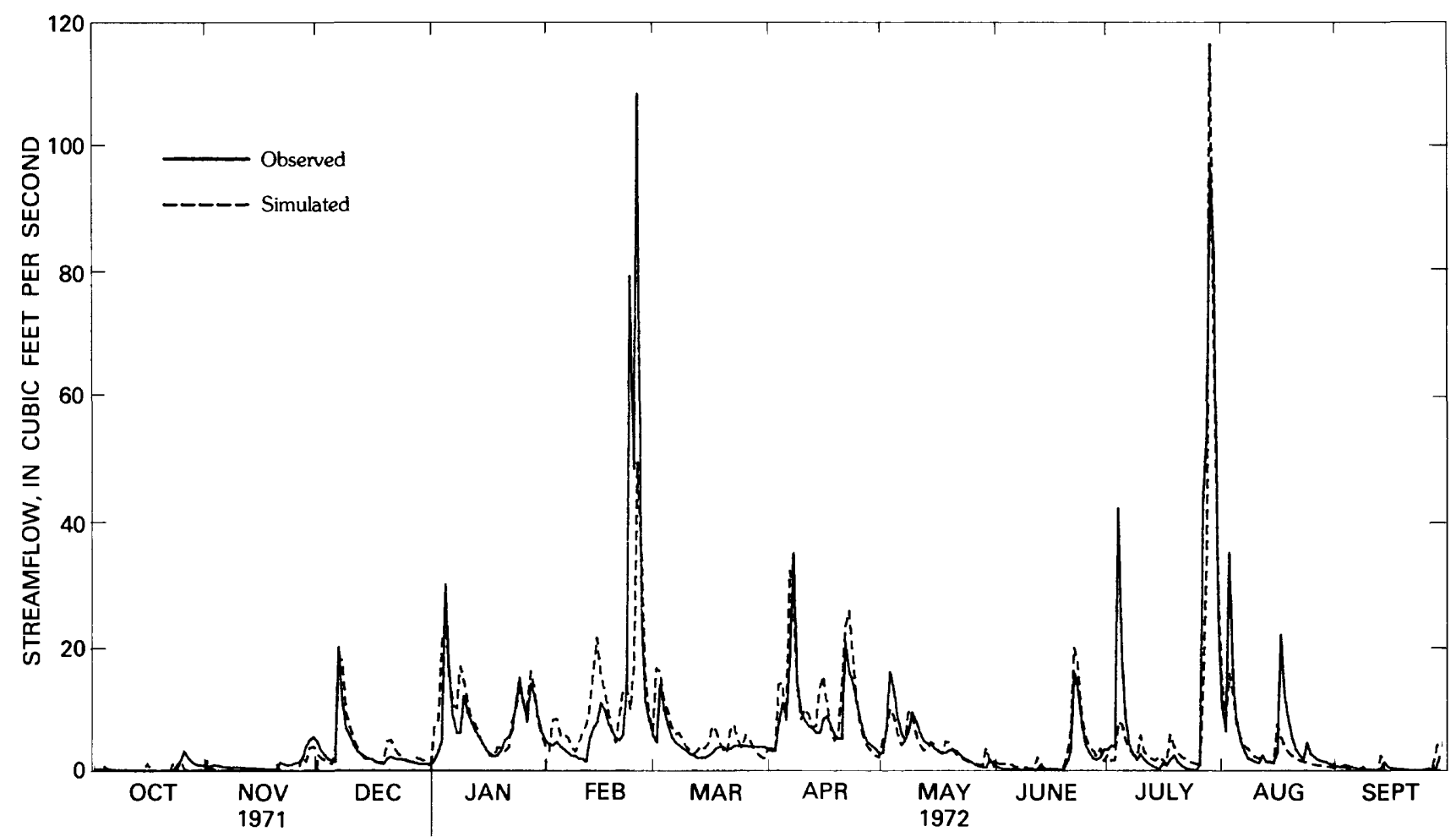

Figure 17. Observed and simulated daily mean streamflow at Collison Creek near Nallen, October 1971-September 1972.

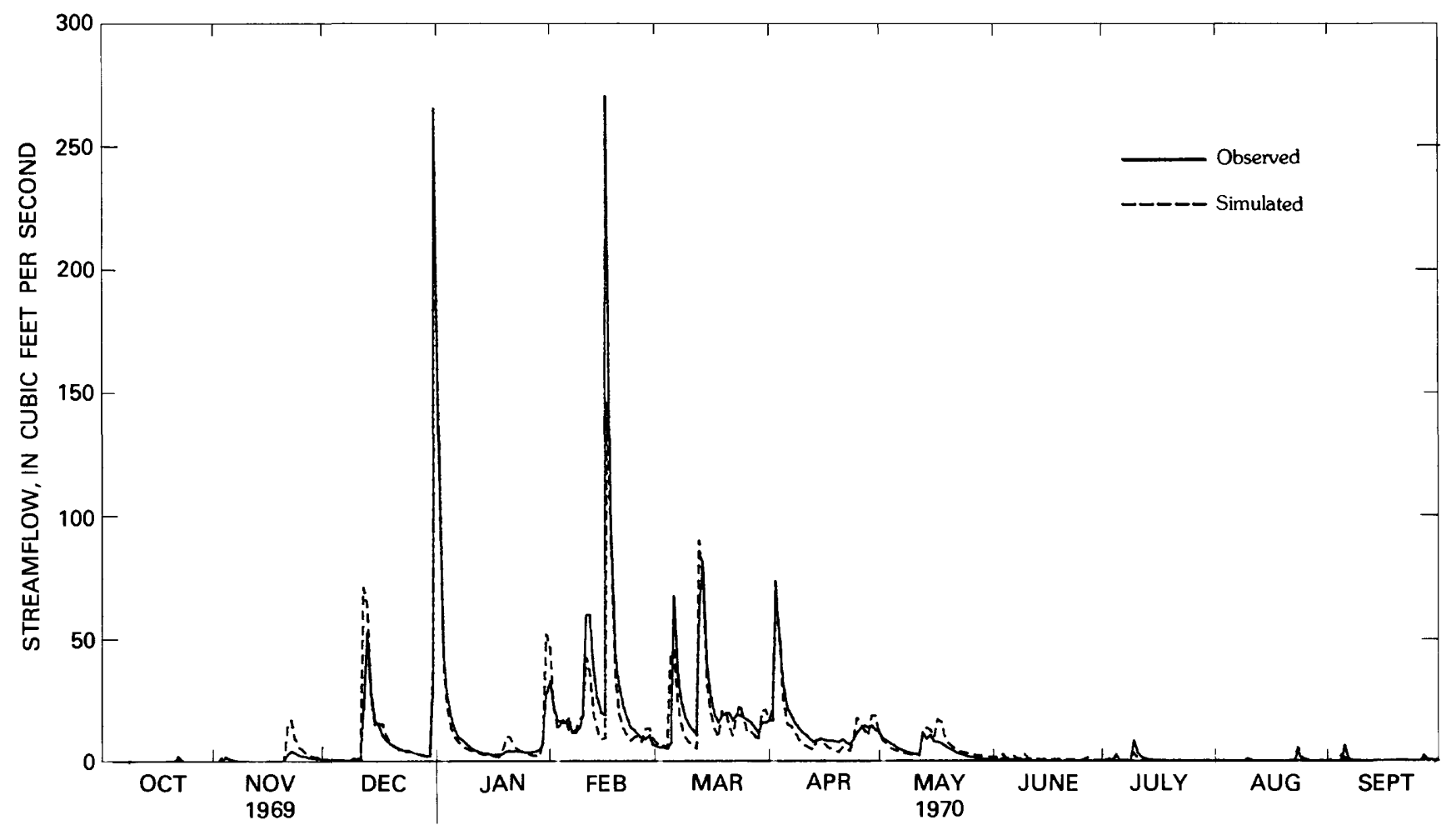

Figure 18. Observed and simulated daily mean streamflow at Drawdy Creek near Peytona, October 1969-September 1970. 


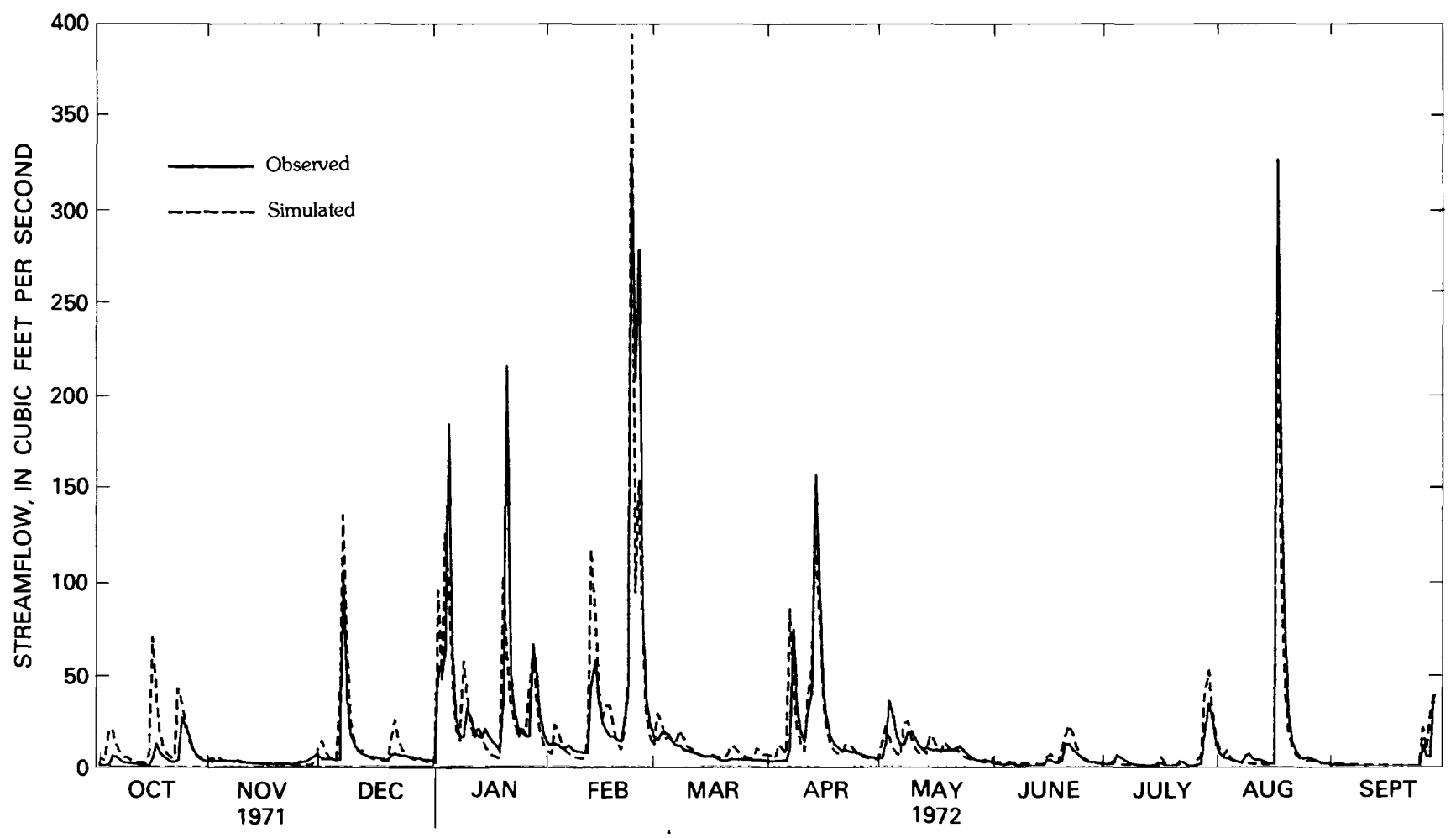

Figure 19. Observed and simulated daily mean streamflow at Brier Creek at Fanrock, October 1971-September 1972.

Differences between predicted and observed daily discharges at Horsecamp Run, Gilmer Run, and Collison Creek generally were greatest during winter (February and March) (figs. 15-17). These sites are located in the higher mountainous areas of the State, where the lowest temperatures and greatest snowfall accumulations occur. Simulated discharges generally were greater than observed discharges during early February and less than observed discharges during late February and early March. This probably results from a combination of the following factors: (1) no records are available for periods of ice-affected discharge, and some precipitation records are lost, (2) the model parameters that influence the rate and timing of snowpack accumulation and snowmelt during periods of extremely cold weather are defined inadequately, and (3) the model is unable to simulate the effects of ice and frozen ground on streamflow. In general, differences between predicted and observed daily discharges were lowest during fall, summer, and spring.

Model-calibration results for mined sites-Drawdy and Brier Creeks - are based on 1970 and 1972 water-year data, respectively. Observation of the hydrographs in figures 18 and 19 also indicates that predicted daily-mean discharges at the sites generally are in close agreement with observed discharges.

Annual precipitation and measured and simulated annual runoff for the period of simulated record at all sites are given in table 4 . The difference between simulated and measured annual discharge volumes also is given in table 4 , both as a volume error and as a percent-difference error in terms of measured discharge. Examination of the table indicates that the errors between observed and simulated annual flow volumes for all sites ranged from +0.14 (1 percent) to -6.29 inches (14 percent). The smallest mean annual volume error for the period of simulated record was at Drawdy Creek -+0.01 inch, or less than 1 percent. The largest mean annual volume error for the period of simulated record was at Brier Creek -+0.90 inch, or 4 percent.

Indices used to assess the model's ability to simulate longer term records are monthly and annual discharge volumes (fig. 20, table 5), and duration of daily flows for the periods of simulated record (figs.21-25).

Comparison of monthly and total annual runoff volumes shown in figure 20 and in table 5 indicates that monthly runoff errors during calibration ranged from -0.01 ( 2 percent) to +2.08 inches ( 77 percent), whereas average monthly runoff errors during verification ranged from -0.01 ( 0 percent) to +1.20 inches ( 71 percent) (table 5). The largest errors occurred during summer and fall when observed flow volumes were usually lowest. Total annual runoff errors during calibration ranged from -0.36 (1 percent) to +5.43 inches ( 20 percent); average total annual runoff errors during verification ranged from $+0.26(1$ percent) to -1.84 inches ( 8 percent). In general, accumulated runoff during winter (December-March) was less than observed, and accumulated runoff during summer 
Table 4. Summary of annual precipitation, observed and simulated annual runoff, and associated error for the period of simulated record

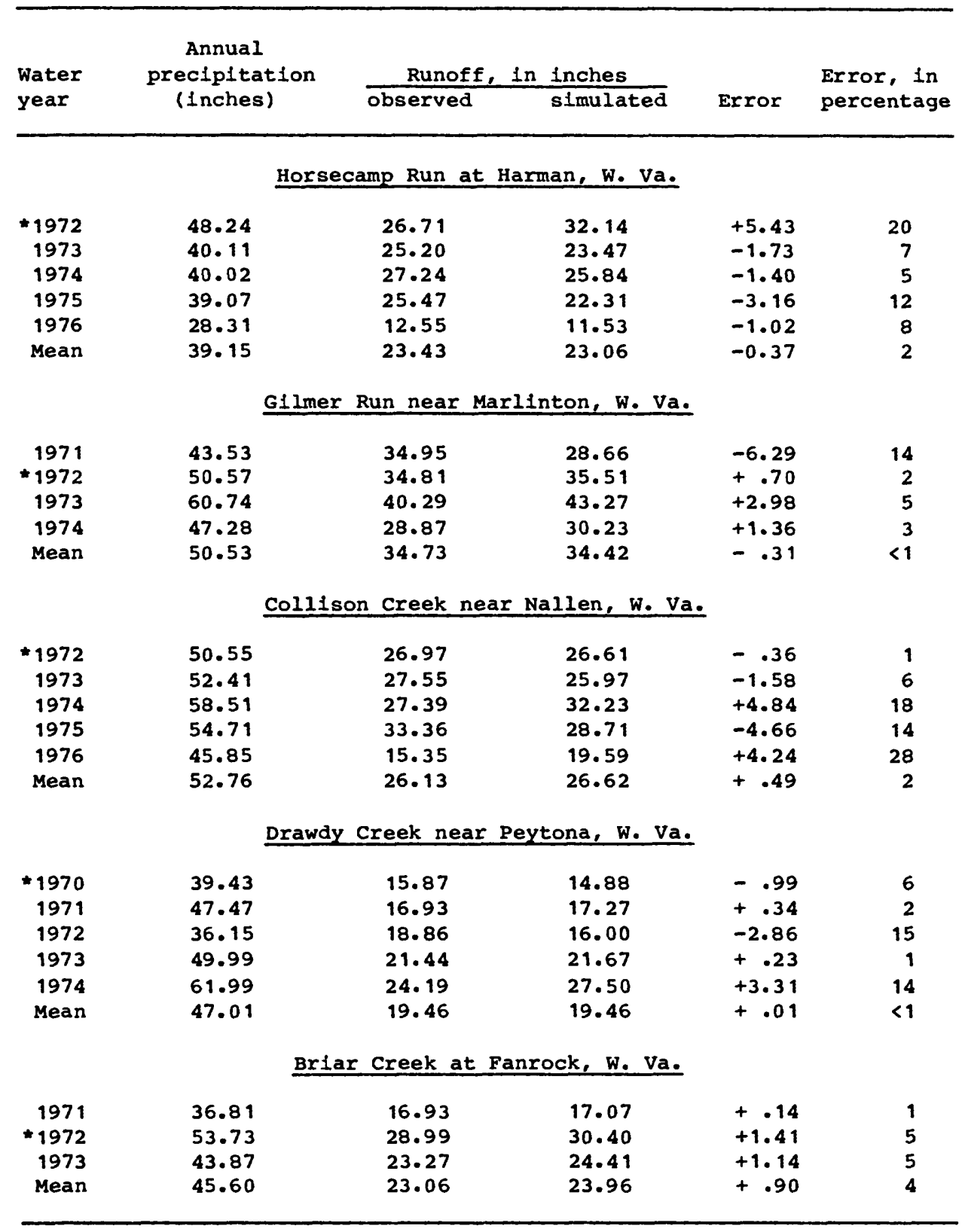

- Calibration year.

(June-September) was greater than observed at most sites for the calibration and verification simulations. During winter periods, the errors probably resulted from inadequate precipitation input and inadequate definition of model parameters that affect snowpack accumulation and snowmelt runoff. During summer periods, the errors probably resulted from inadequate definition of model parameters that affect soil-moisture accretion and depletion rates, subsurface and ground-water storage volumes, and flowrouting coefficients.
Curves showing duration of daily flow for all sites, prepared from observed data and data generated by the models, are shown in figures 21 through 25 . The duration curves show flow variability and distribution in time throughout the range of flow at the sites during the simulated period. Inspection of the duration curves shows that the variations in simulated flow generally closely reproduce the variations in observed flow for all sites. The differences between the curves are small throughout the range of flow at most sites. 

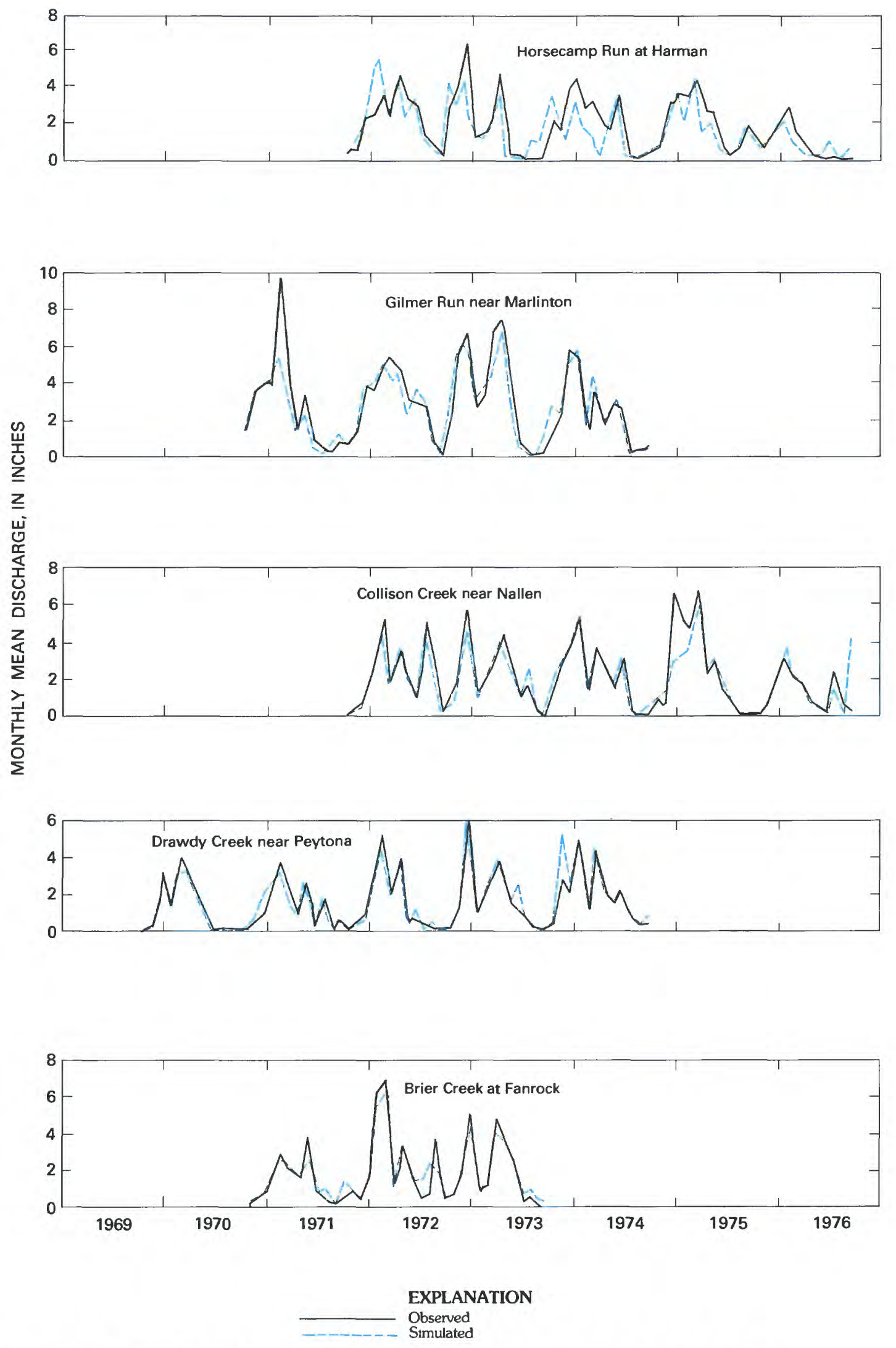

Figure 20. Observed and simulated monthly mean discharge at study basins, 1969-76.

Simulation of Rainfall-Runoff Response in Mined and Unmined Watersheds in Coal Areas

25 
Table 5. Summary of observed and simulated monthly and annual runoff during calibration and verification period of record for study basins

[In inches, except where indicated]

Unmined basins

Horsecamp Run at Harman

\begin{tabular}{|c|c|c|c|c|c|c|c|c|}
\hline \multirow[t]{2}{*}{ Month } & \multicolumn{4}{|c|}{$\begin{array}{l}\text { 19721/ } \\
\text { Runoff }\end{array}$} & \multicolumn{4}{|c|}{$\begin{array}{l}\text { 1973-1976 } 2 / \\
\text { Mean Runoff }\end{array}$} \\
\hline & Observed & $\begin{array}{l}\text { Simu- } \\
\text { lated }\end{array}$ & Error & $\begin{array}{l}\text { Error, In } \\
\text { percentage }\end{array}$ & Observed & $\begin{array}{l}\text { Simu- } \\
\text { lated }\end{array}$ & Error & $\begin{array}{l}\text { Error, in } \\
\text { percentage }\end{array}$ \\
\hline Oct & 0.56 & 0.66 & +0.10 & 18 & 1.81 & 2.67 & +0.86 & 48 \\
\hline Nov & .64 & 1.02 & +.38 & 59 & 1.93 & 1.90 & -.03 & 2 \\
\hline Dec & 2.38 & 1.92 & -.46 & 19 & 3.76 & 2.82 & -.94 & 25 \\
\hline $\operatorname{Jan}$ & 2.69 & 4.77 & +2.08 & 77 & 3.11 & 2.79 & -.32 & 10 \\
\hline Feb & 3.64 & 5.56 & +1.92 & 53 & 2.72 & 2.51 & -.21 & 8 \\
\hline Mar & 3.19 & 5.15 & +1.96 & 61 & 2.94 & 2.30 & -.64 & 22 \\
\hline Apr & 4.69 & 5.25 & +.56 & 12 & 2.58 & 1.91 & -.67 & 26 \\
\hline May & 3.35 & 2.44 & -.91 & 27 & 1.23 & 1.17 & -.06 & 5 \\
\hline June & 3.16 & 2.98 & -.18 & 6 & 1.30 & 1.08 & -.22 & 17 \\
\hline July & 1.44 & 1.42 & -.02 & 1 & 0.28 & 0.39 & +.11 & 39 \\
\hline Aug & .70 & .77 & +.07 & 10 & .27 & .48 & +.21 & 78 \\
\hline Sept & .27 & .20 & -.07 & 26 & .71 & .78 & +.07 & 10 \\
\hline $\begin{array}{l}\text { Total } \\
\text { annual }\end{array}$ & 26.71 & 32.14 & +5.43 & 20 & 22.64 & 20.80 & -1.84 & 8 \\
\hline
\end{tabular}

Gilmer Run near Marlinton

\begin{tabular}{|c|c|c|c|c|c|c|c|c|}
\hline \multirow[t]{2}{*}{ Month } & \multicolumn{4}{|c|}{$\begin{array}{l}\text { 19721/ } \\
\text { Runoff }\end{array}$} & \multicolumn{4}{|c|}{$\begin{array}{l}\text { 1971, 1973-1974/ } \\
\text { Mean Runoff } \\
\end{array}$} \\
\hline & Observed & $\begin{array}{l}\text { S1mu- } \\
\text { lated }\end{array}$ & Error & $\begin{array}{r}\text { Error, In } \\
\text { percentage }\end{array}$ & Observed & $\begin{array}{l}\text { Simu- } \\
\text { lated }\end{array}$ & Error & $\begin{array}{l}\text { Error, In } \\
\text { percentage }\end{array}$ \\
\hline Oct & 0.68 & 0.71 & +0.03 & 4 & 1.68 & 2.88 & +1.20 & 71 \\
\hline Nov & 1.16 & 1.50 & +.34 & 29 & 3.91 & 4.32 & +0.41 & 10 \\
\hline Dec & 3.83 & 4.29 & +.46 & 12 & 5.54 & 5.28 & -.26 & 5 \\
\hline Jan & 3.68 & 4.90 & +1.22 & 33 & 3.97 & 4.67 & +.70 & 18 \\
\hline Feb & 5.07 & 5.38 & +.31 & 6 & 4.85 & 3.99 & -.86 & 18 \\
\hline $\operatorname{Mar}$ & 5.55 & 4.13 & -1.42 & 26 & 4.91 & 4.37 & -.54 & 11 \\
\hline Apr & 4.96 & 4.75 & -.21 & 4 & 3.61 & 3.51 & -.10 & 3 \\
\hline May & 3.07 & 2.20 & -.87 & 28 & 3.50 & 2.84 & -.66 & 19 \\
\hline June & 2.95 & 3.18 & +.23 & 8 & 1.62 & 1.07 & -.55 & 34 \\
\hline July & 2.88 & 3.22 & +.34 & 12 & 0.41 & 0.2 & -.13 & 32 \\
\hline Aug & .86 & .95 & +.09 & 10 & .22 & .20 & -.02 & 9 \\
\hline Sept & .12 & .30 & +.18 & 150 & .50 & .63 & +.13 & 26 \\
\hline $\begin{array}{l}\text { Total } \\
\text { annual }\end{array}$ & 34.81 & 35.51 & +.70 & 2 & 34.71 & 34.04 & -.68 & 2 \\
\hline
\end{tabular}

Collison Creek near Nallen

\begin{tabular}{|c|c|c|c|c|c|c|c|c|}
\hline \multirow[t]{2}{*}{ Month } & \multicolumn{4}{|c|}{$\begin{array}{l}\text { 19721/ } \\
\text { Runoff }\end{array}$} & \multicolumn{4}{|c|}{$\begin{array}{l}\text { 1973-1976-2/ } \\
\text { Mean Runoff }\end{array}$} \\
\hline & Observed & $\begin{array}{l}\text { Stmu- } \\
\text { lated }\end{array}$ & Error & $\begin{array}{r}\text { Error, In } \\
\text { percentage }\end{array}$ & Observed & $\begin{array}{l}\text { Slmu- } \\
\text { lated }\end{array}$ & Error & $\begin{array}{r}\text { Error, in } \\
\text { percentage }\end{array}$ \\
\hline Oct & 0.23 & 0.15 & -0.08 & 35 & 0.78 & 0.98 & +0.20 & 26 \\
\hline Nov & .47 & .22 & -.25 & 53 & 2.28 & 1.54 & -.74 & 32 \\
\hline Dec & 1.32 & 1.57 & +.25 & 19 & 4.50 & 3.55 & -.95 & 21 \\
\hline Jan & 3.22 & 3.82 & +.60 & 19 & 3.93 & 3.92 & -.01 & 0 \\
\hline Feb & $5 \cdot 38$ & 4.49 & -.89 & 17 & 2.69 & 2.67 & +.02 & 1 \\
\hline Mar & 1.83 & 2.43 & +.60 & 33 & 3.96 & 4.57 & +.61 & 15 \\
\hline Apr & 3.73 & 4.48 & +.75 & 20 & 2.75 & 2.92 & +.17 & 6 \\
\hline May & 1.91 & 1.78 & -.13 & 7 & 1.94 & 2.27 & +.33 & 17 \\
\hline June & .86 & 1.21 & +.35 & 41 & 1.42 & 1.59 & +.17 & 12 \\
\hline July & 5.19 & 4.21 & -.98 & 19 & 1.25 & 1.21 & -.04 & 3 \\
\hline Aug & 2.61 & 2.00 & -.61 & 23 & .24 & .17 & -.07 & 29 \\
\hline Sept & .22 & .26 & +.04 & 18 & .21 & 1.25 & +1.04 & 495 \\
\hline \multicolumn{9}{|l|}{ Total } \\
\hline annual & 26.97 & 26.62 & -.36 & 1 & 25.95 & $26 \cdot 64$ & +.69 & 3 \\
\hline
\end{tabular}


Table 5. Summary of observed and simulated monthly and annual runoff during calibration and verification period of record for study basins-Continued

[In inches, except where indicated]

\section{Mined basins}

Drawdy Creek near Peytona

\begin{tabular}{|c|c|c|c|c|c|c|c|c|}
\hline \multirow[t]{2}{*}{ Month } & \multicolumn{4}{|c|}{$\begin{array}{l}\text { 19701/ } \\
\text { Runoff }\end{array}$} & \multicolumn{4}{|c|}{$\begin{array}{l}1971-1974 \text { - } \\
\text { Mean Runoff }\end{array}$} \\
\hline & Observed & $\begin{array}{l}\text { Slmu- } \\
\text { lated }\end{array}$ & Error & $\begin{array}{l}\text { Error, In } \\
\text { percentage }\end{array}$ & Observed & $\begin{array}{l}\text { Simu- } \\
\text { lated }\end{array}$ & Error & $\begin{array}{r}\text { Error, In } \\
\text { percentage }\end{array}$ \\
\hline Oct & 0.08 & 0.06 & -0.02 & 25 & 0.30 & 0.28 & -0.02 & 7 \\
\hline Nov & .23 & .40 & +.17 & 74 & 1.38 & 2.06 & +.68 & 49 \\
\hline Dec & 3.06 & 3.27 & +.21 & 7 & 2.59 & 2.63 & +.04 & 2 \\
\hline Jan & 1.45 & 1.53 & +.08 & 6 & 2.80 & 2.73 & -.07 & 3 \\
\hline $\begin{array}{l}\text { Feb } \\
\text { Mar }\end{array}$ & $\begin{array}{l}4.34 \\
3.34\end{array}$ & $\begin{array}{l}3.10 \\
3.10\end{array}$ & $\begin{array}{l}-1.24 \\
-.24\end{array}$ & $\begin{array}{r}29 \\
7\end{array}$ & $\begin{array}{l}3.13 \\
2.97\end{array}$ & $\begin{array}{l}2.75 \\
2.75\end{array}$ & $\begin{array}{l}-.38 \\
-.22\end{array}$ & $\begin{array}{r}12 \\
7\end{array}$ \\
\hline Apr & 2.27 & 2.00 & -.27 & 12 & 2.89 & 2.80 & -.09 & 3 \\
\hline May & .74 & .91 & +.17 & 23 & 1.61 & 1.58 & -.03 & 2 \\
\hline June & .08 & .19 & +.11 & 138 & 1.03 & 1.65 & +.62 & 60 \\
\hline July & .14 & .13 & -.01 & 7 & .85 & .95 & +.10 & 12 \\
\hline Aug & .05 & .11 & +.06 & 120 & .38 & .18 & -.20 & 53 \\
\hline Sept & .09 & .08 & -.05 & 56 & .45 & .28 & -.17 & 38 \\
\hline $\begin{array}{l}\text { Total } \\
\text { annual }\end{array}$ & 15.87 & 14.88 &.- .99 & 6 & 20.38 & 20.64 & +.26 & 1 \\
\hline
\end{tabular}

Brier Creek at Fanrock

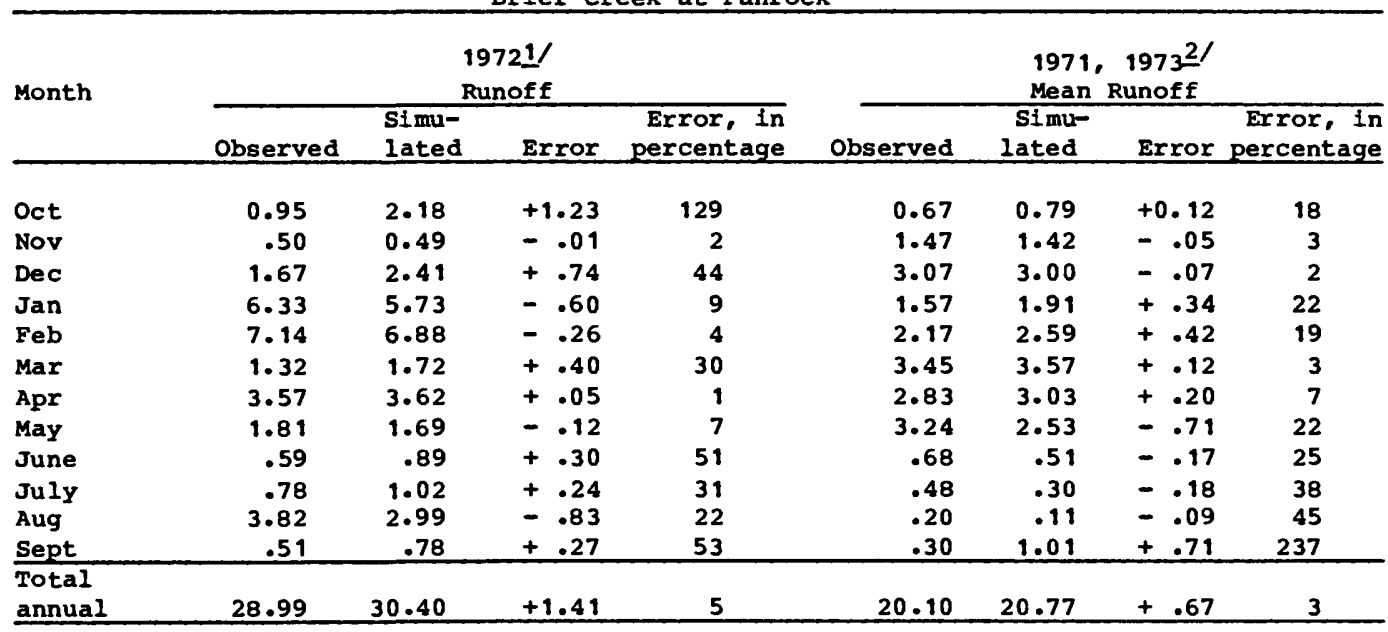

1/ Calibration period

$\underline{2}$ / verification period

The agreement between simulated and observed discharges during the calibration and verification periods (figs. 15-25; tables 4, 5) indicates that the models simulated observed streamflow conditions in the basins for the study period reasonably well. Sources of modeling error, noted in earlier sections, include (1) inadequate definition of model parameters that affect the rate and timing of snowpack accumulation and snowmelt runoff during periods of extremely cold weather, (2) inadequaie definition of model parameters that affect soil-moisture accretion and depletion rates, subsurface and ground-water storage volumes, and flow-routing coefficients, and (3) missing precipitation records.
The major source of modeling error probably is inadequate definition of meteorologic (precipitation, air temperature, and pan-evaporation) input data. Model simulations were based on precipitation data from only one rain gage in each basin, from air-temperature data from National Weather Service climate sites usually within 10 miles of the study basins, and from pan-evaporation data from a recording site generally more than 50 miles from the basins.

It should be noted that the periods of record used for calibration and verification simulations are short term and do not reflect the extremes of climatic conditions needed for long-term extension of streamflow records or determination of streamflow characteristics. 


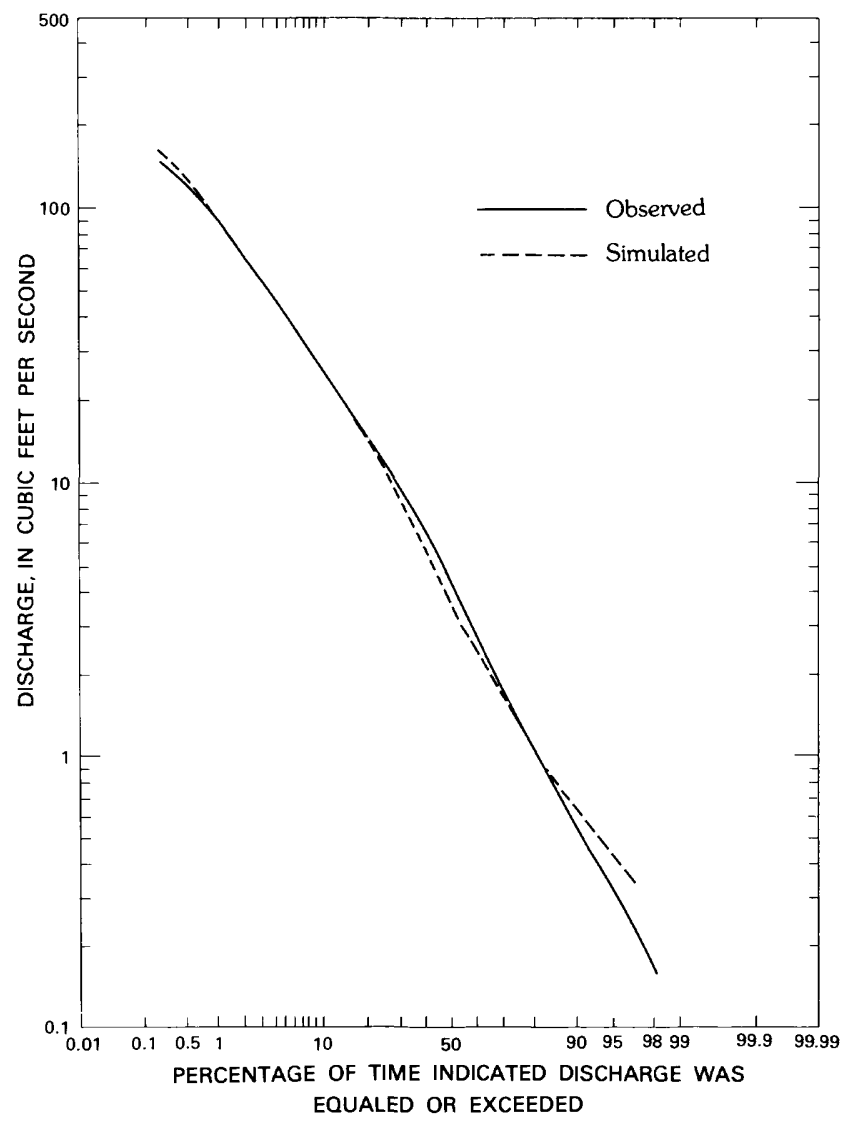

Figure 21. Duration curves of daily mean discharge at Horsecamp Run at Harman, 1972-76.

The derived model parameters are not unique; at best, they represent average values for the HRU's (unmined and mined) in the basins and are an index to, rather than a measure of, the physical system. These approximations introduce a source of error that may limit the accuracy of predictions obtained by the models. However, on the basis of observed and simulated discharge comparisons and the given constraints on input data, the calibrated models may be sufficiently adequate to permit a general examination of the hydrologic system of the study basins. Model estimates must be qualified as being the best initial estimates based on current assumptions, input data constraints, model imperfections, and achieved levels of accuracy. Better definition and longer term records of meteorologic and hydrologic data within the study areas, in conjunction with additional refinement of specific model parameters, should improve accuracy and predictive capability.

\section{Water Budget}

In addition to simulating daily mean streamflow, the calibrated model simulates water budgets that may be used to examine the hydrologic system of the basins. Block diagrams of the water budgets for the study basins during

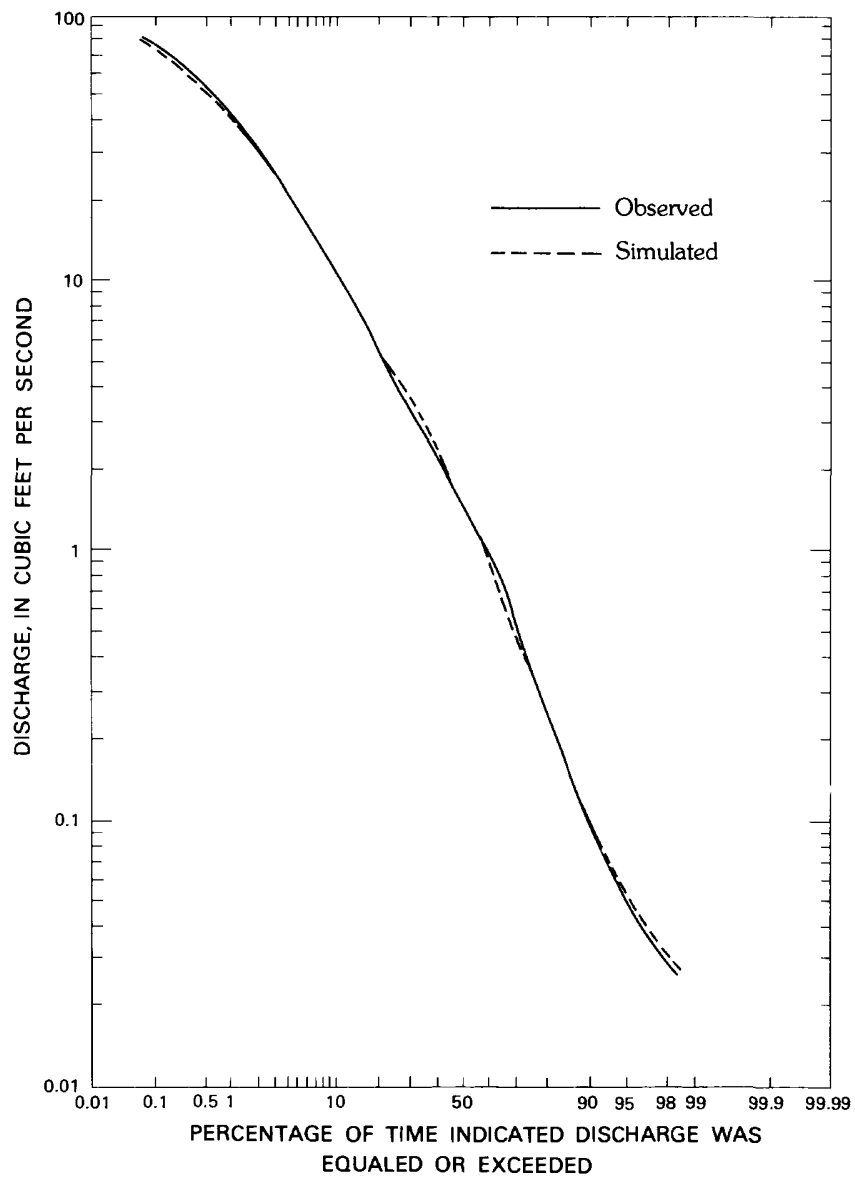

Figure 22. Duration curves of daily mean discharge at Gilmer Run near Marlinton, 1971-74.

the 1972-73 water years are shown in figure 26 . The water-budget analyses are based on the assumptions that model-parameter values given in table A-3 of appendix A are appropriate and that no changes in basin ground-water or surface-water storage occurred in the unmined basins. Because the coal beds and rocks generally dip away from parts of the mined basins, it was assumed that underground transfer of water from Drawdy and Brier Creek basins to adjacent basins mainly occurred through underground mines that extend beyond the basin boundaries. Although some of the contour strip mines in the basins extend beyond the basin boundaries, it was assumed that surface runoff diverted along strip terraces into adjacent basins was negligible.

The simulated water budgets in figure 26 show that total annual runoff for the unmined basins-Horsecamp Run, Gilmer Run, and Collison Creek-averaged 60 percent (31.16 inches) of average annual precipitation at the sites during the period of simulation. Annual evapotranspiration losses averaged 40 percent ( 20.95 inches) of precipitation. Of the total annual runoff, approximately 91 percent (28.30 inches) was surface runoff (surface runoff plus 


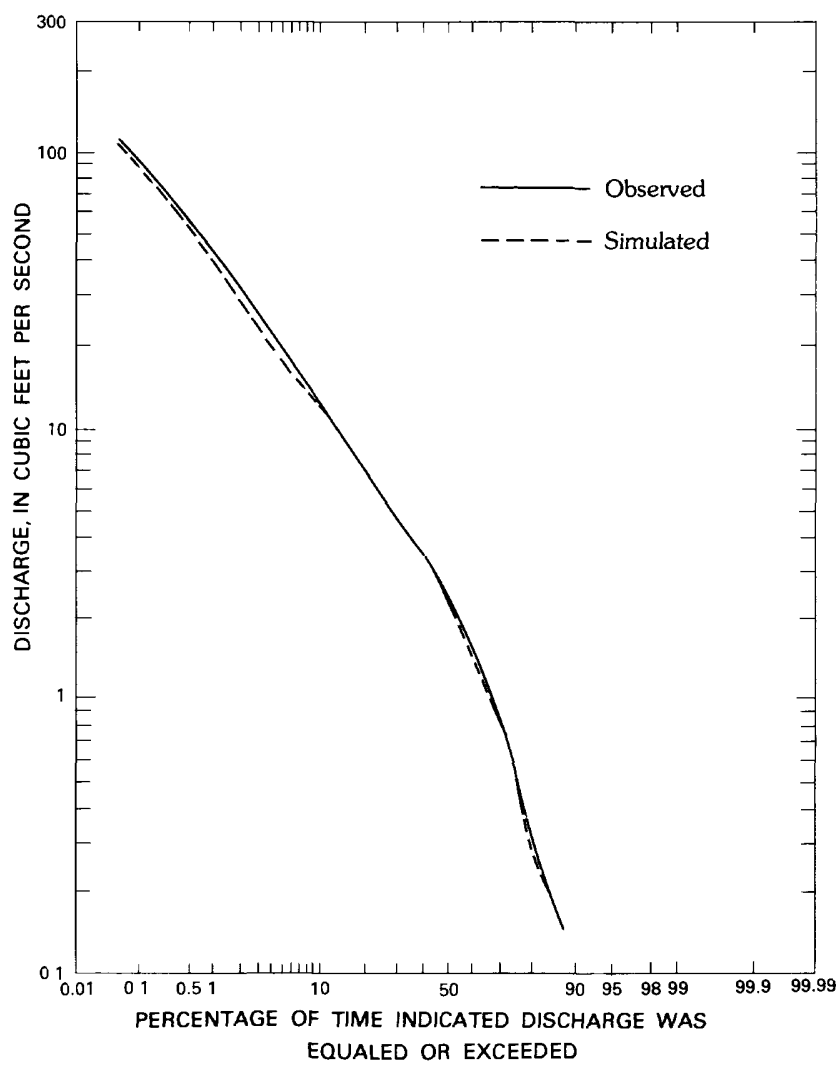

Figure 23. Duration curves of daily mean discharge at Collison Creek near Nallen, 1972-76.

subsurface flow) and 9 percent (2.86 inches) was groundwater discharge.

Simulations show that total annual runoff at Brier Creek basin averaged approximately 52 percent $(27.40$ inches) of average annual precipitation. Annual evapotranspiration losses averaged 43 percent (22.53 inches), and interbasin transfer of water (ground-water sink) averaged 5 percent ( 2.37 inches). The surface-flow and ground-waterdischarge components of total streamflow are substantially different from those of the unmined basins. Of the total annual runoff in Brier Creek basin, approximately 79 percent (21.59 inches) was surface and subsurface runoff and 21 percent (5.81 inches) was ground-water discharge. The large base-flow component of total annual runoff in Brier Creek basin probably results from significant rock permeability and water stored in the rocks and in underground mines.

Of the basins studied, Drawdy Creek had the lowest average total annual runoff -43 percent (18.84 inches) of precipitation. Annual evapotranspiration losses averaged 49 percent (21.38 inches) of average annual precipitation. Of the total annual runoff, approximately 74 percent (13.89 inches) was surface and subsurface runoff and 26 percent (4.95 inches) was ground-water discharge. Simulations

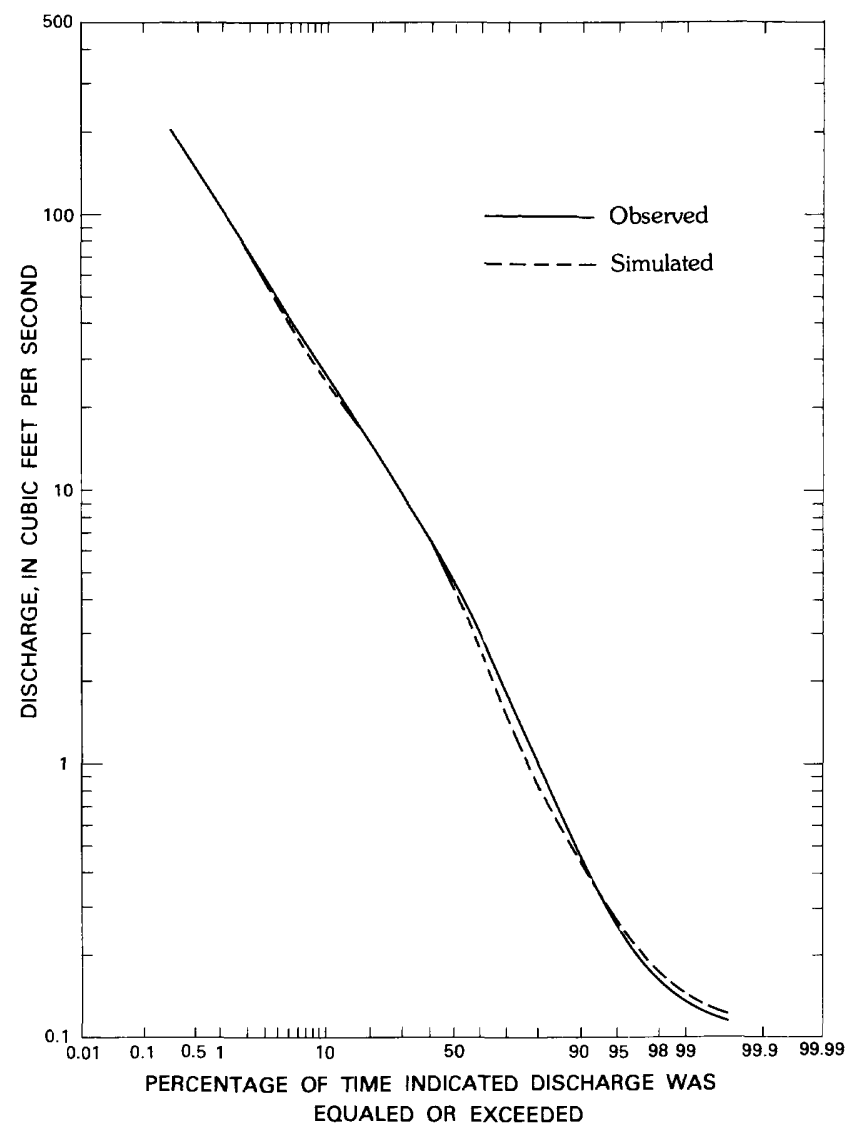

Figure 24. Duration curves of daily mean discharge at Drawdy Creek near Peytona, 1970-74.

indicate that interbasin transfer of water from Drawdy Creek basin averaged 8 percent ( 3.35 inches) of average annual precipitation. The low total annual runoff in Drawdy Creek basin probably results primarily from increased recharge of precipitation and runoff losses to ground water in the rocks and in underground mines. Most of the increase in ground-water storage is assumed to be lost to a groundwater sink - interbasin transfer of ground water by natural gravity drainage and (or) mine pumpage from underground mines to adjacent basins.

A more detailed water budget for the entire period of simulated record at all sites is given in table 6. Inflow consisted of observed precipitation and outflow consisted of evapotranspiration, surface runoff, subsurface flow, ground-water discharge, and interbasin transfer of water (ground-water sink). The change in storage in the basins consisted of changes in soil moisture and in the subsurface and ground-water reservoirs between the beginning and end of each year. The errors in the annual water budget range from less than 1 percent to about 10 percent. The larger errors result from adjustments applied to observed winter precipitation data to reflect the influence of elevation on precipitation in the basin. 


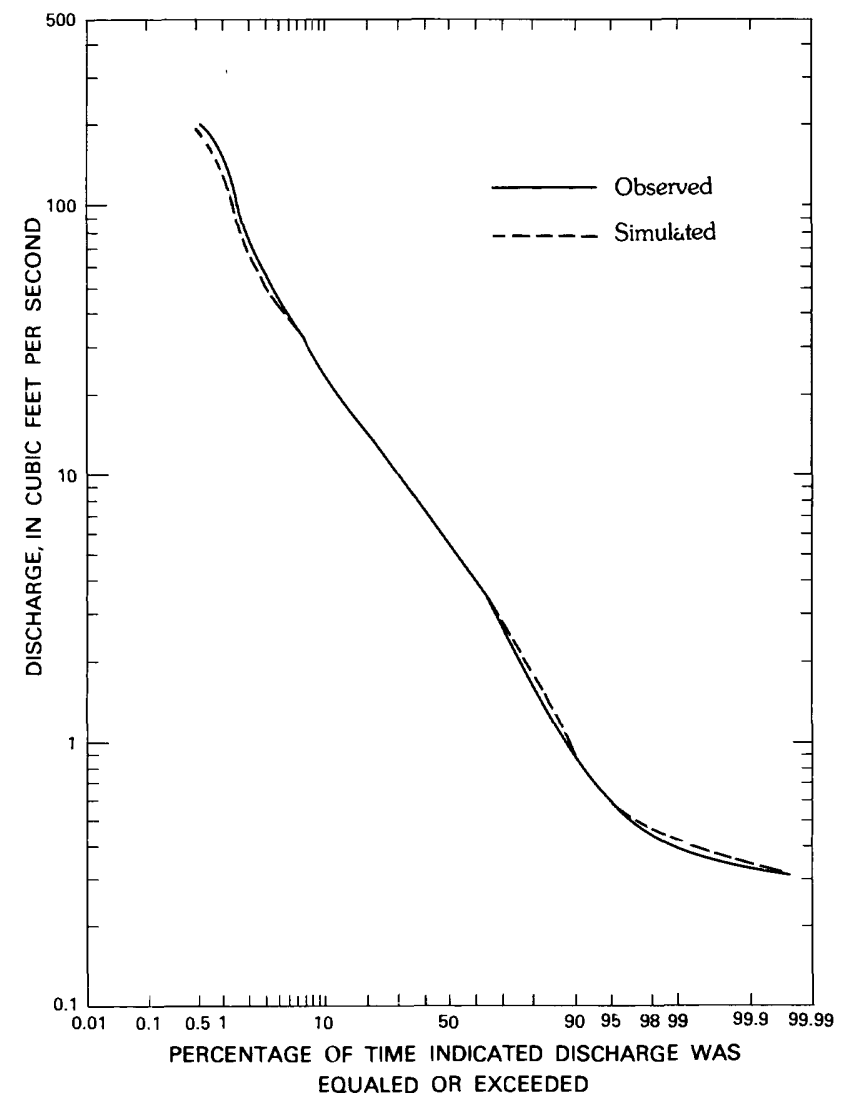

Figure 25. Duration curves of daily mean discharge at Brier Creek at Fanrock, 1971-73.

A comparison of simulated water-budget items in table 6 indicates that the component percentages of total annual runoff at all sites were very similar to those shown in figure 26. Total annual runoff (overland runoff plus groundwater runoff) at the unmined sites ranged from 11.53 inches at Horsecamp Run in 1976 to as much as 43.27 inches at Gilmer Run in 1973 (table 6). Total annual runoff at the mined sites ranged from 14.88 inches at Drawdy Creek in 1970 to as much as 30.39 inches at Brier Creek in 1972.

Recharge to the ground-water system generally is equal to the ground-water-discharge component of total streamflow plus interbasin transfer of ground water to points outside the basin, plus the change in ground-water storage in the basins. The simulated water budget in table 6 shows that annual recharge in the unmined basins ranged from 1.14 inches at Horsecamp Run in 1976 to as much as 4.21 inches at Collison Creek in 1974. The overall average annual recharge for all unmined basins was 2.65 inches. The range of simulated annual recharge for the unmined basins agrees reasonably well with the range of recharge (from less than 3.00 to 5.50 inches) reported by Hopkins (1970) and Bain and Friel (1972) for nearby basins of similar physical settings and land use.
Simulated annual recharge in the mined basins ranged from 5.58 inches at Brier Creek in 1971 to as much as 10.53 inches at Drawdy Creek in 1974 (table 6). The overall average annual recharge for the mined sites was 7.71 inches.

Approximately 2.93 inches, or 38 percent of the average annual recharge for the mined basins, was lost to ground-water sinks. Recharge in the mined basins is greater than in the unmined basins. This probably results, in part, from increased permeability of surface rocks caused by surface subsidence fractures associated with collapsed underground mines. Such fractures would increase downward percolation of precipitation and would capture groundwater discharge and surface and subsurface flow to deeper rocks and (or) underground mine workings.

Simulations further showed that annual evapotranspiration losses at all sites ranged from 16.35 inches at Gilmer Run in 1972 to 30.69 inches at Drawdy Creek in 1974. Average annual evapotranspiration losses for all sites ranged from 18.37 inches at Gilmer Run to 25.57 inches at Collison Creek. The range of simulated evapotranspiration losses for the study basins was similar to that $(22.75$ to 27.46 inches) reported by Chang and others (1976) for other nearby basins.

\section{Hypothetical Conditions}

The predictive capabilities of the calibrated models permit an evaluation of the basin hydrologic responses (streamflow, ground-water storage, and water budget) to various hypothetical mining conditions. Predictions of hydrologic responses to hypothetical mining, however, are subject to a high degree of uncertainty because of the sparsity and reliability of data on climate, soil, surface water, and ground water in the basins. Predicted hydrologic responses produced by the models should be viewed only as rough order-of-magnitude estimates of possible hydrologic changes that could occur in response to various hypothetical mining situations.

A series of model simulations in which two hypothetical mining situations were imposed on Drawdy Creek and Brier Creek basins was made to evaluate the possible hydrologic consequences of mining for streamflow. In the analysis, model parameters representing land-use conditions in both basins were modified to reflect (1) total unmined conditions and (2) a 100-percent increase over actual mining. All other model inputs and parameters were assumed to remain constant and, thus, were not evaluated.

\section{Streamflow}

The effects of the hypothetical mining conditions on streamflow and basin storage in Drawdy Creek and Brier Creek basins are shown in figures 27 and 28, in which duration curves of simulated streamflow are compared. The data in figures 27 and 28 show substantial differences in 

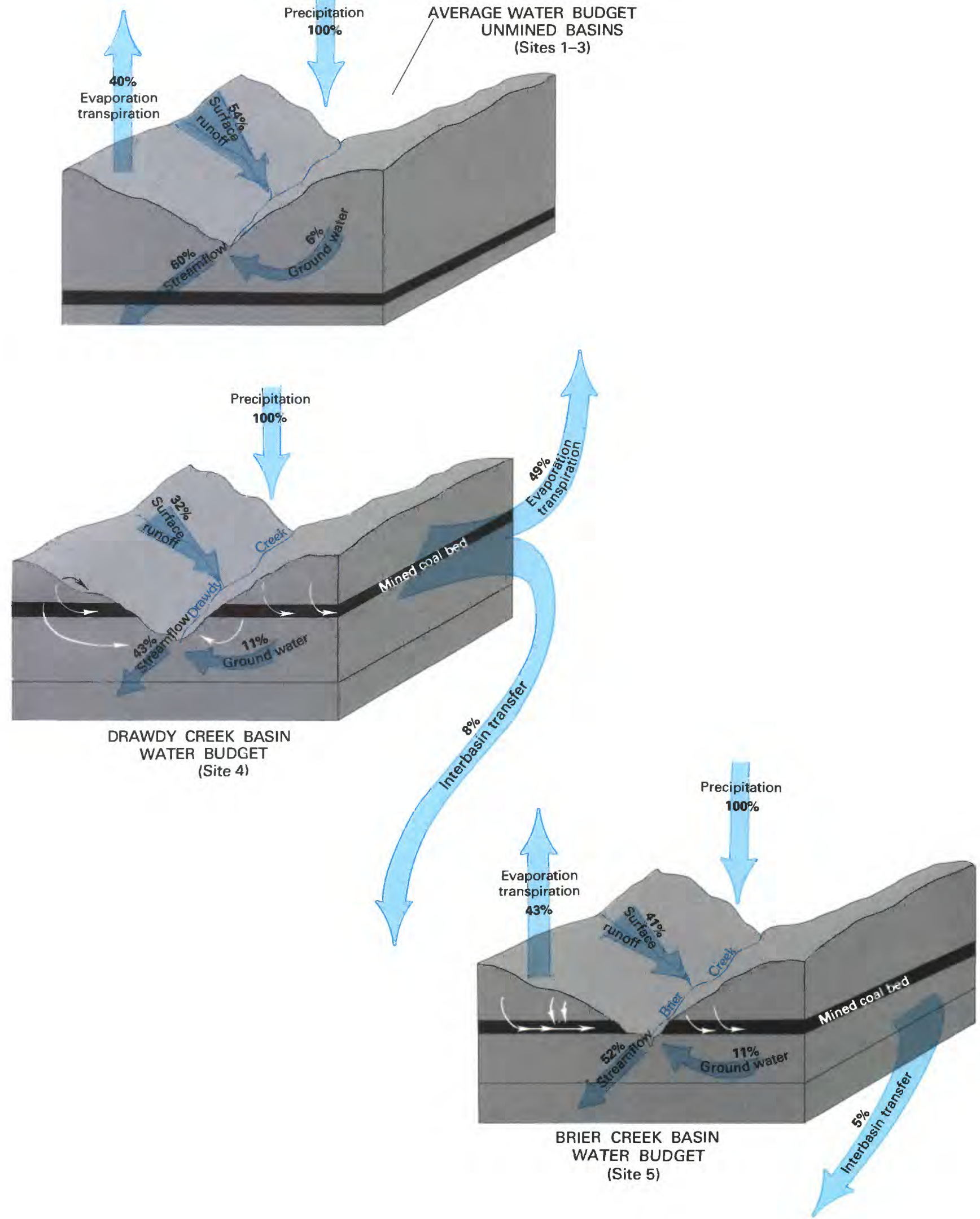

Figure 26. Approximate percentages of simulated water-budget components for mined and unmined basins, October 1 , 1971, to September 30, 1973. (Modified from Hobba, 1981.) 


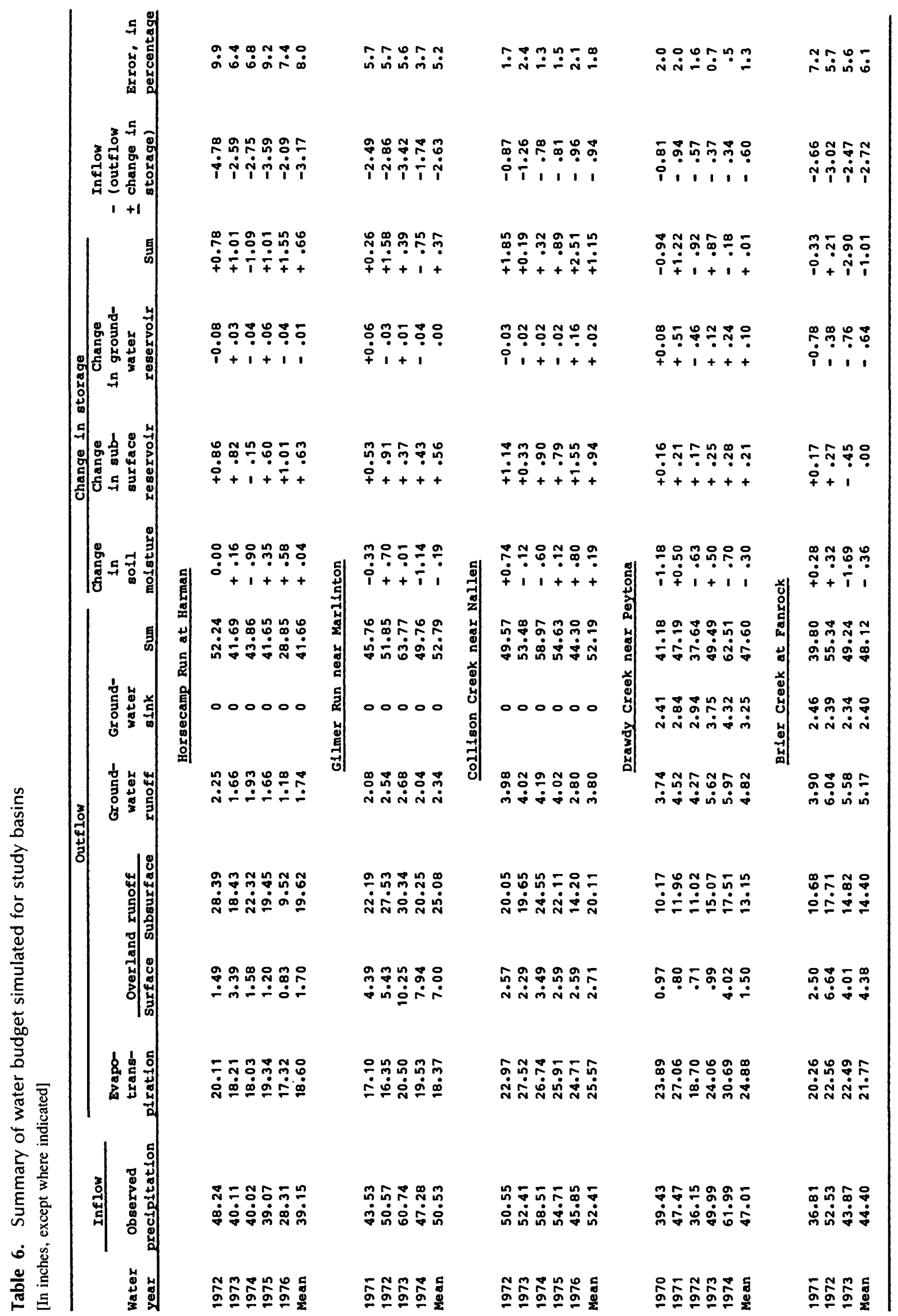




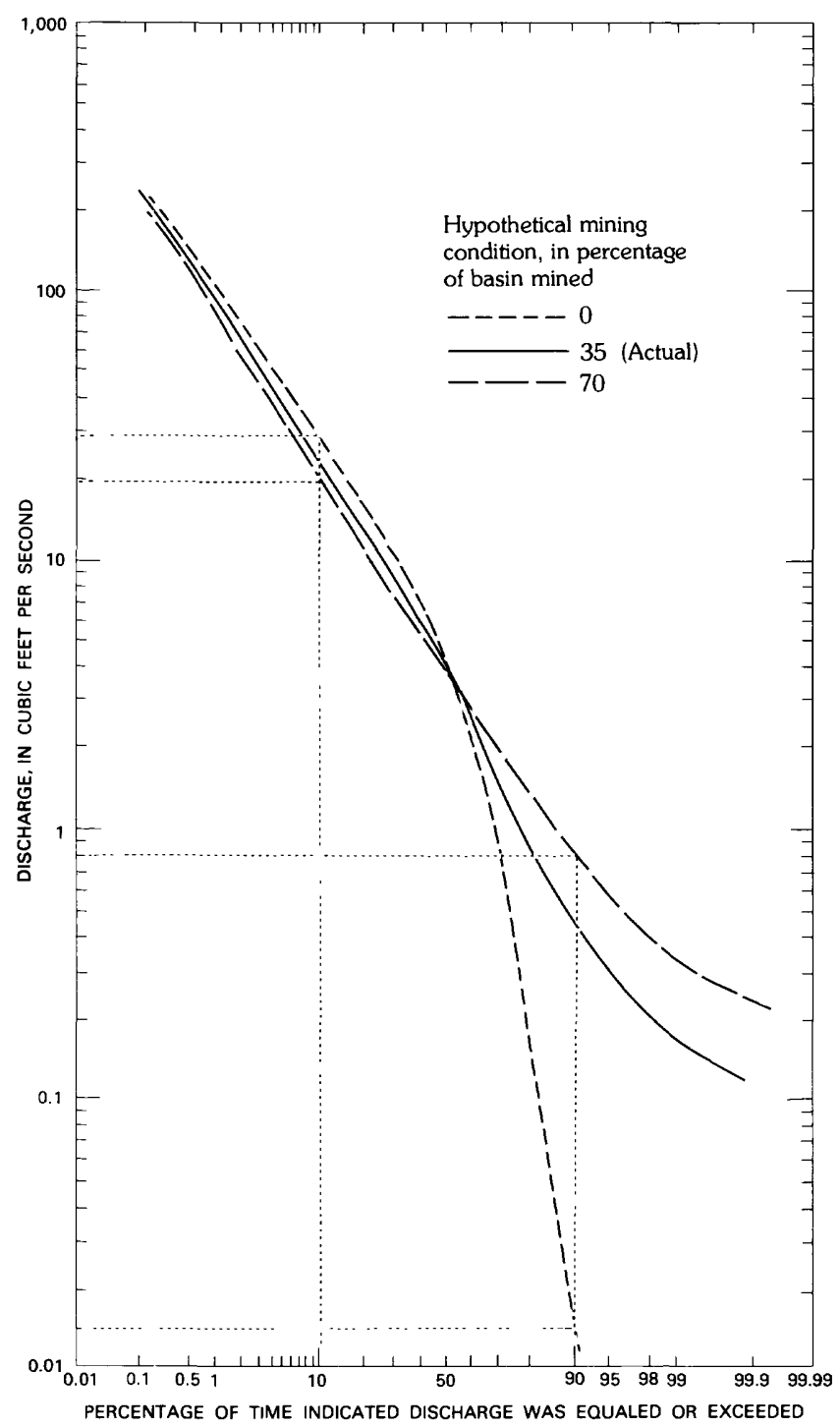

Figure 27. Duration curves of daily mean streamflow simulated under various mining conditions at Drawdy Creek near Peytona, 1970-74.

variability of simulated streamflow in response to the hypothetical changes imposed in the mined basins.

The flow-duration curves that represent unmined situations at both sites are steep throughout the range of flow and reflect limited contribution of water from groundwater storage, which is typical of most unmined basins. In contrast, the curves that represent mined conditions flatten at the lower end and indicate well-sustained ground-water discharge. The differences between the curves for both sites show that discharges of ground water increase directly with the increase in mining in the basins.

Results shown in figure 27 indicate that flow at the 90-percent duration point for the 70-percent mined condition in Drawdy Creek basin would increase by about 0.80 cubic feet per second, or 6,000 percent more than that

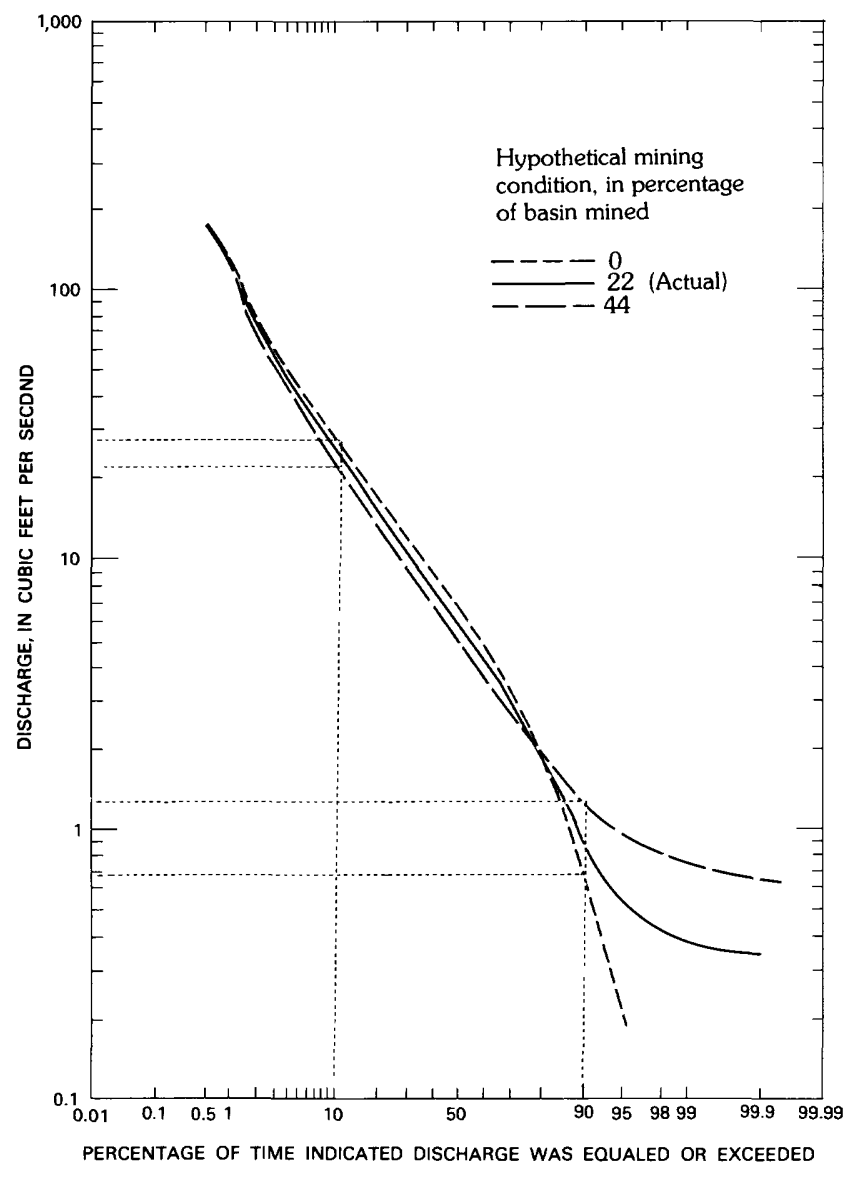

Figure 28. Duration curves of daily mean streamflow simulated under various mining conditions at Brier Creek at Fanrock, 1971-73.

simulated for the unmined condition. Similarly, results shown in figure 28 indicate that flow at the 90 -percent duration point for the 44-percent mined condition in Brier Creek basin would increase by about 0.58 cubic feet per second, or 90 percent. The increase in low flows reflects the increase in ground-water storage in the rocks and in underground mines that would result from the increase of mining in the basins.

Further inspection of the flow-duration curves in figures 27 and 28 indicates that the flows in the medium- to high-flow range decrease in response to increased mining in the basins. Results for Drawdy Creek basin (fig. 27) indicate that the flow at the 10-percent duration point for the 70-percent mined condition would decrease by about 9 cubic feet per second, or 30 percent less than that simulated for the unmined condition. For Brier Creek basin (fig. 28), the simulated flow at the 10-percent duration point for the 44-percent mined condition would decrease by about 6 cubic feet per second, or 20 percent. The decrease in flows in the medium to high range reflect surface and subsurface flow losses and increased recharge to ground water. 
At high flows (5-percent duration point and less) the curves in figures 27 and 28 appear to converge for all mining conditions. This indicates that runoff would become similar during high rainfall events, regardless of the magnitude of mining in the basin.

\section{Water Budget}

The water budgets simulated for actual and hypothetical mining conditions in Drawdy Creek basin for the 1970-74 water years and in Brier Creek basin for the 1971-73 water years are given in table 7. The data in table 7 show that the average total annual runoff at Drawdy Creek would decrease in response to increased mining in the basin. Results indicate that for the 35-percent mined condition (the actual condition), average total annual runoff would be about 2.88 inches, or 13 percent less than simulated for the hypothetical unmined condition; for the 70-percent mined condition, average total runoff would be about 26 percent less.

When the percentage of basin mined was increased to 70 percent, average annual recharge in Drawdy Creek basin increased by about 6.57 inches, or 134 percent more than that simulated for the unmined condition. Most of the additional recharge would be diverted to a ground-water sink - interbasin transfer of water from the basin by natural drainage and (or) mine pumpage from underground mines to adjacent basins. Simulations indicate that average annual ground-water sink losses, which were assumed to be zero for the unmined condition, would be 3.25 inches for the actual mined condition and would increase to about 6.50 inches for the 70-percent mined condition.

The data for Brier Creek basin in table 7 similarly show decreased annual runoff, increased recharge to ground water, and increased losses to a ground-water sink in response to increased mining in the basin. Results indicate that, for the 44-percent mined condition, average total annual runoff would be about 2.31 inches, or 9 percent, less than simulated for the unmined condition; average annual recharge would increase by about 2.15 inches, or 37 percent, and ground-water-sink losses would average about 4.80 inches.

The effects of mining on annual runoff in Drawdy and Brier Creek basins are shown in figures 29 and 30, in which the seasonal distribution of the components of average total monthly runoff are compared. Simulations indicate that surface and subsurface flow in both basins would decrease substantially during most of the year in response to increased mining in the basins. These losses would be greatest during the wet season (winter-spring), when precipitation is greatest. Results for Drawdy Creek basin (fig. 29) indicate that, for the 70-percent mined condition, average subsurface flow during March would decrease by about 0.95 inch, or 39 percent, from that simulated for the unmined condition. For the 44-percent mined condition in
Brier Creek basin (fig. 30), average subsurface flow during March would decrease by about 0.26 inch, or 14 percent.

Ground-water discharge for Drawdy and Brier Creek basins would also decrease during the wet season, but would increase during the dry season (summer-fall). Results for Drawdy Creek basin (fig. 29) indicate that for the 70-percent mined condition, average ground-water discharge during March would decrease by about 0.22 inch, or 26 percent, from that simulated for the unmined condition; however, average ground-water discharge during September would increase by about 0.13 inch, or 430 percent. For the 44-percent mined condition in Brier Creek basin (fig. 30 ), average ground-water discharge during March would decrease by about 0.28 inch, or 32 percent, and average ground-water discharge during September would increase by about 0.07 inch, or 100 percent. The decrease in ground-water discharge during the wet season in both basins reflects the combined effects of ground-water-sink losses and the amount of recharge needed to replenish depleted ground-water storage in the rocks and in underground mines. The increase in ground-water discharge during the dry season reflects the increase of ground-water storage in the rocks and in underground mines.

\section{SUMMARY AND CONCLUSIONS}

The U.S. Geological Survey Precipitation-Runoff Modeling System was calibrated and verified for simulating streamflow in five small watersheds in West Virginia. The sites, which have drainage areas ranging from 1.80 to 7.75 square miles, are located in similar geologic and hydrologic settings, but they have different land-use characteristics. Three of the basins-Horsecamp Run, Gilmer Run, and Collison Creek - are relatively undisturbed and are primarily forested, with some grasslands and pasture. The remaining basins-Drawdy and Brier Creeks-are extensively mined for coal (surface in combination with underground) above stream-drainage level. About 2.7 square miles, or 35 percent, of Drawdy Creek basin has been mined, and about 1.57 square miles, or 22 percent, of Brier Creek basin has been mined.

Low-flow measurements at numerous synoptic sites in Drawdy Creek and Brier Creek basins indicate that coal mining has substantially altered the hydrologic systems of these basins. The effects of mining on streamflow in the basins were identified as (1) reduced base flow in stream segments underlain by underground mines, (2) increased base flow in streams that are downdip and stratigraphically below the elevation of the mined coal beds, and (3) interbasin transfer of ground water through underground mines. These changes probably reflect increased permeability of surface rocks caused by subsidence fractures associated with collapsed underground mines in the basins. Such fractures would increase downward percolation of precipi- 


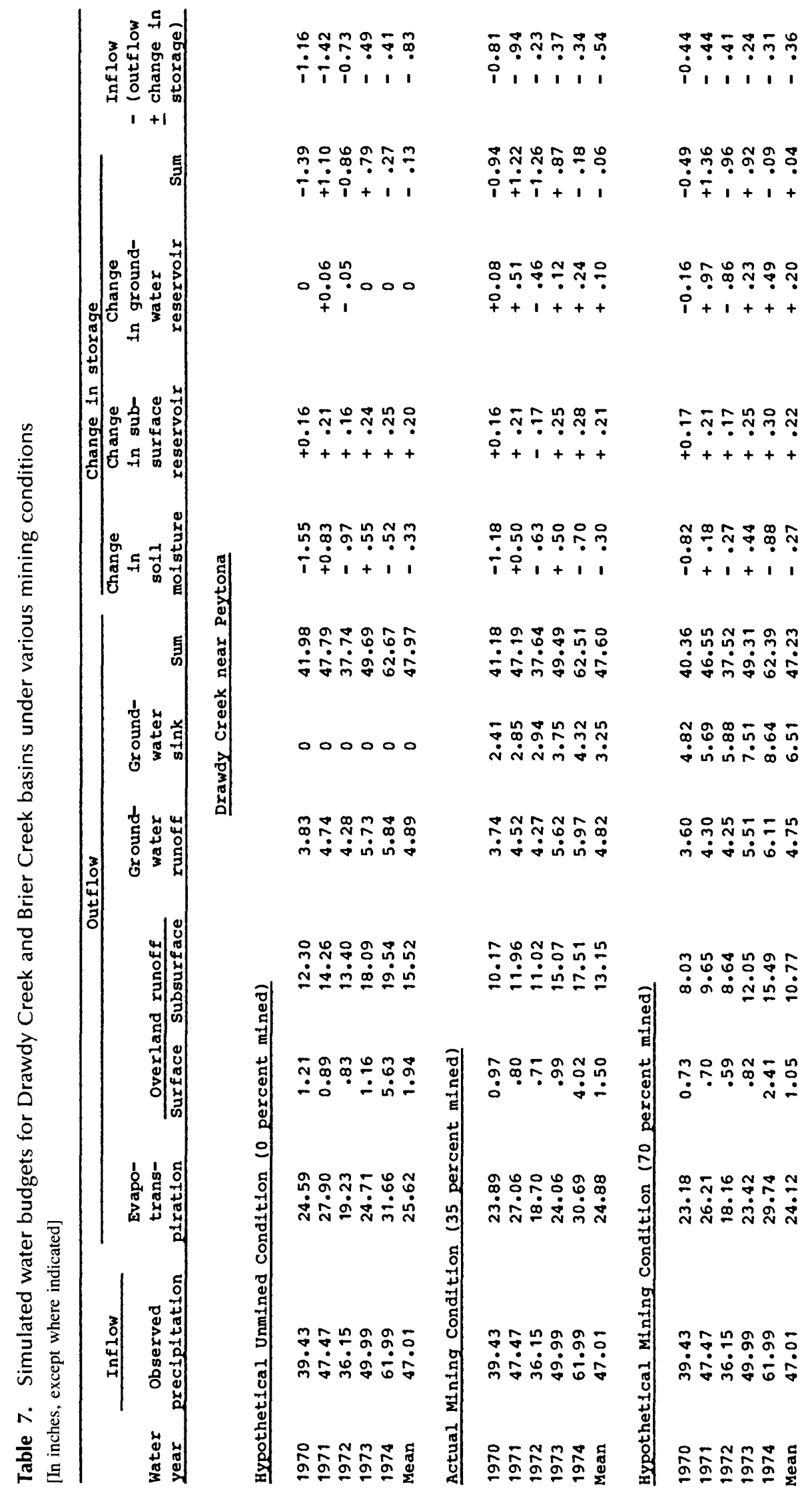




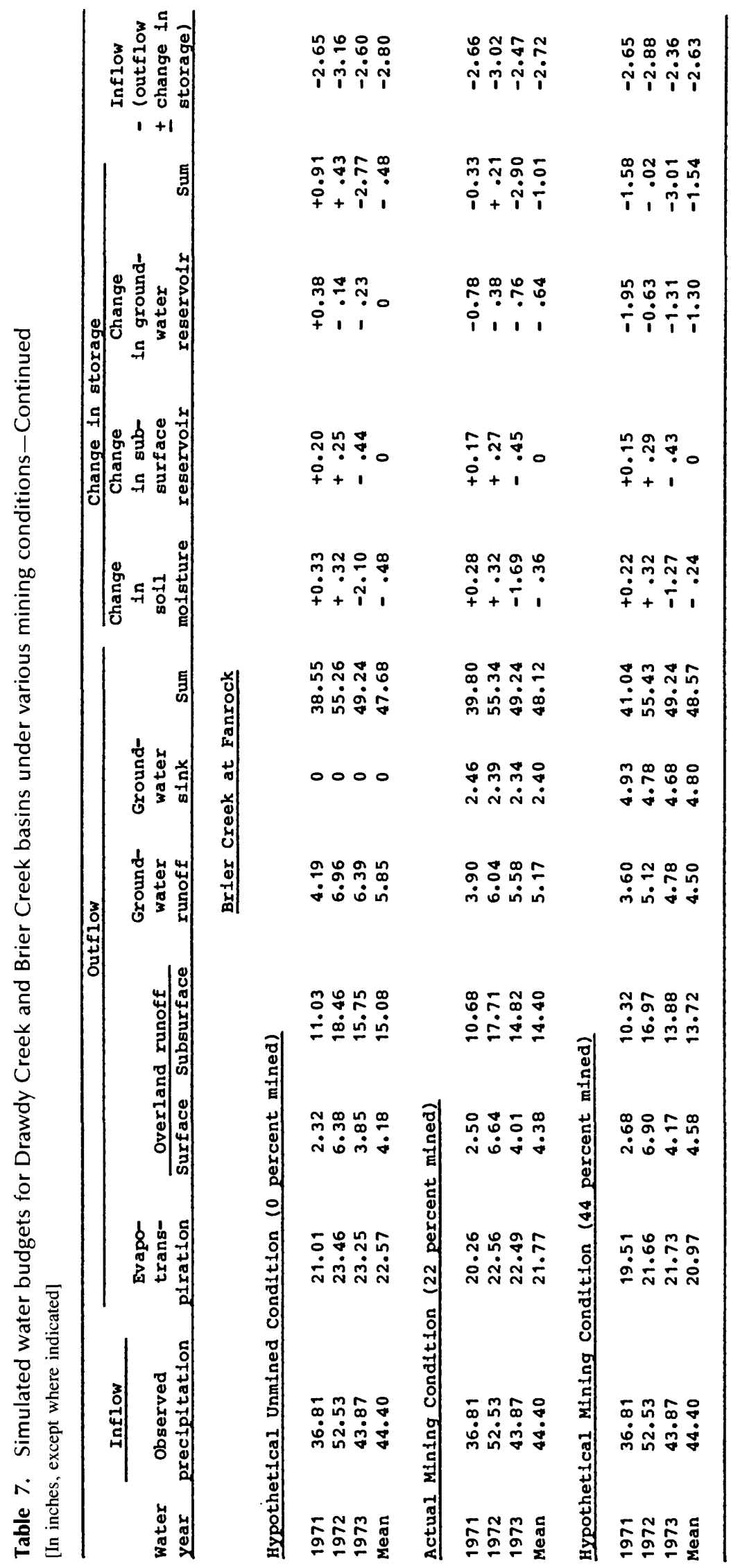



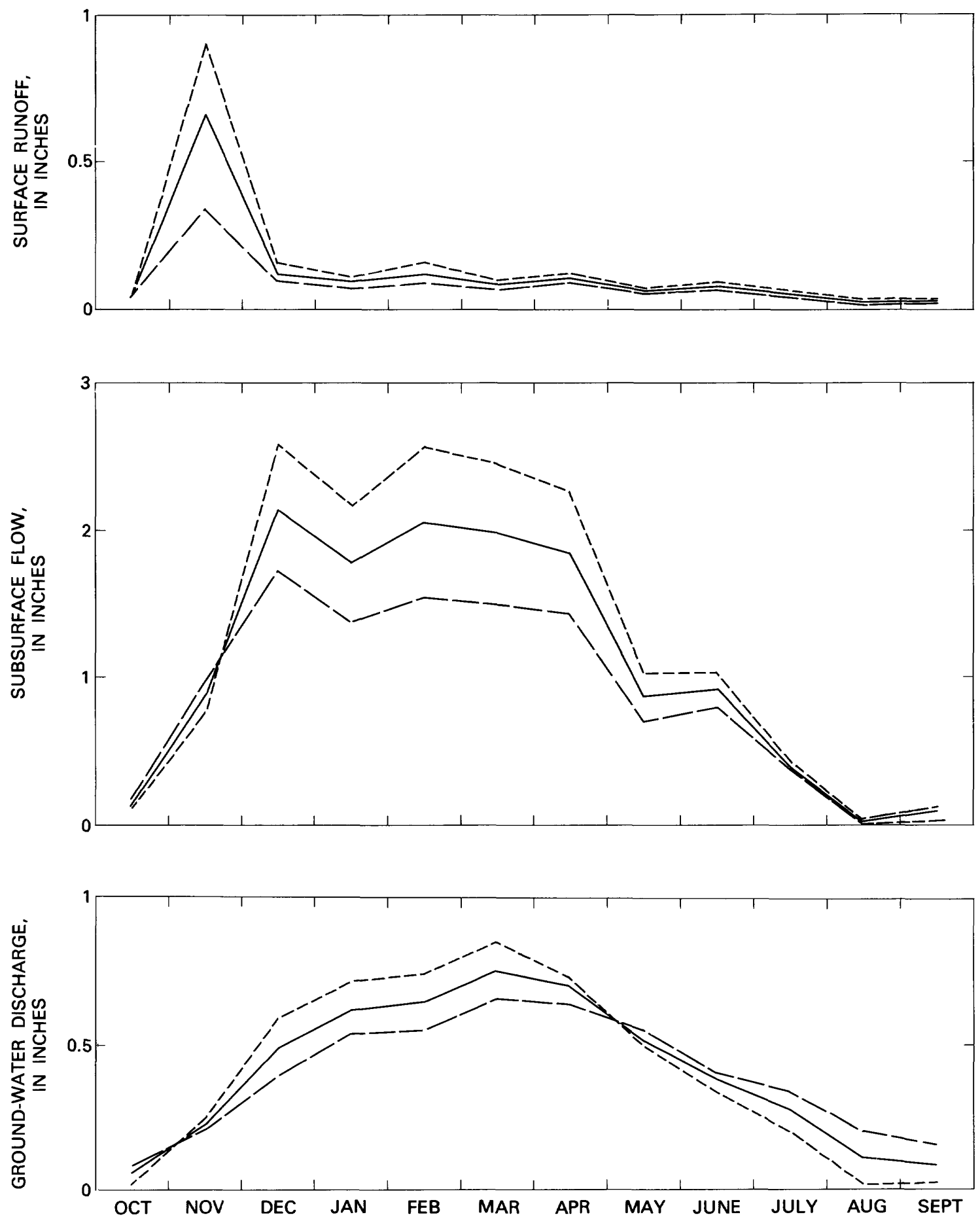

EXPLANATION

Hypothetical mining condition

in percentage of basin mined

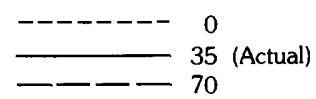

Figure 29. Seasonal distribution of components of average total monthly runoff simulated at Drawdy Creek near Peytona, 1970-74. 

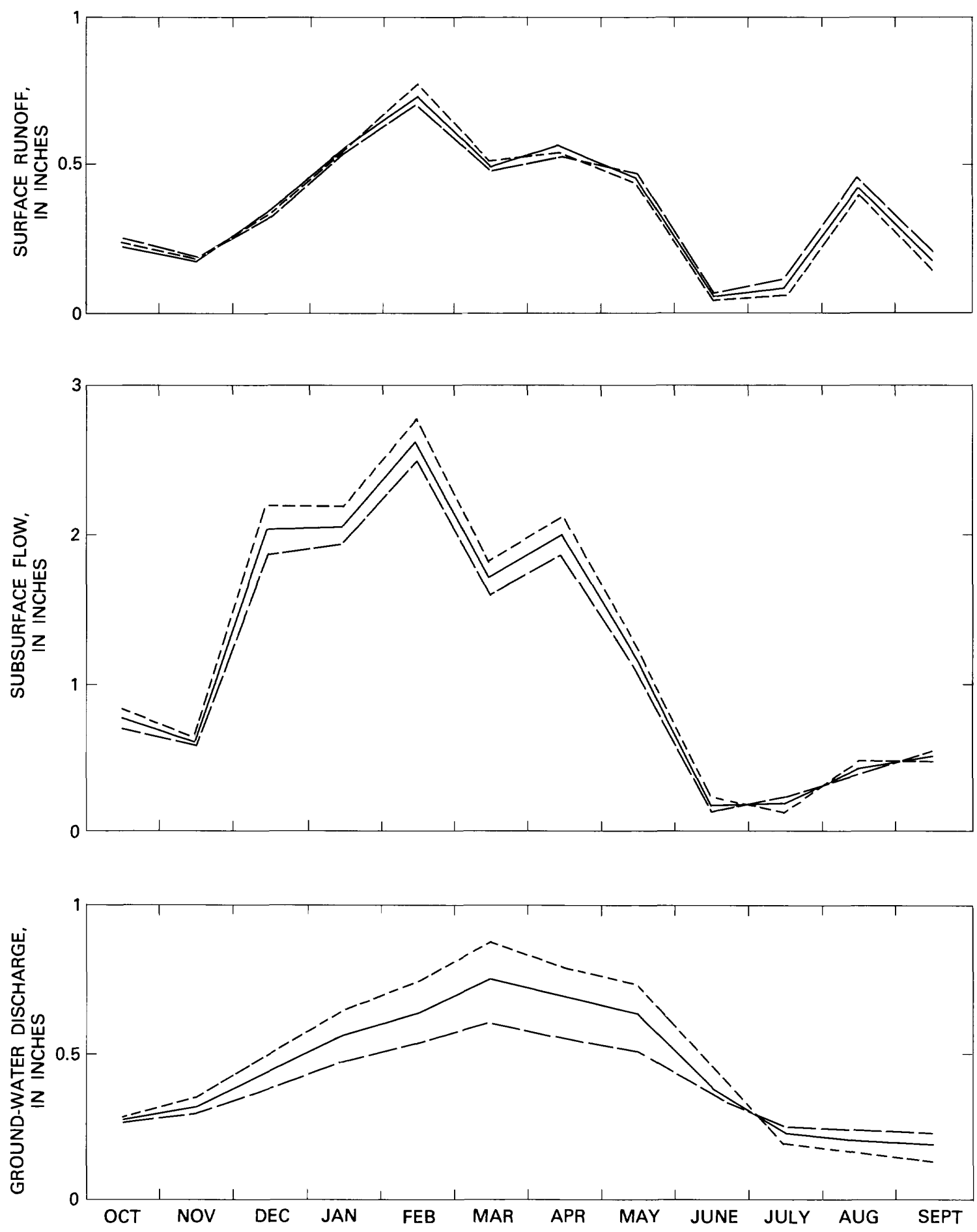

\section{EXPLANATION}

Hypothetical mining condition,

in percentage of basin mined

$$
\begin{array}{ll}
------ & 0 \\
--\sim & 22
\end{array} \text { (Actual) }
$$

Figure 30. Seasonal distribution of components of average total monthly runoff simulated at Brier Creek at Fanrock, 1971-73. 
tation, surface and subsurface flow, and ground-water discharge to deeper rocks or to underground mine workings.

The models of each basin were calibrated with 1 year of precipitation and runoff records and were verified with longer term precipitation and runoff records of 2 to 4 years duration. The adequacy of the models for simulating streamflow was based on comparisons of monthly and annual streamflow volumes, seasonal runoff distribution, minimum and maximum daily mean flows, recession rates, and duration of daily flows. Differences between observed and simulated annual flow volumes ranged from 1 to 28 percent and, for mean annual flow volumes, from less than 1 to 4 percent.

By simulating streamflow, evapotranspiration losses, and changes in basin water storage, the models quantify the hydrologic water balance for each basin during the period of record and provide a means of predicting possible changes in hydrologic response to various hypothetical coal-mining scenarios. Model simulation of the basin water budgets indicate that, during water years 1972-73, total annual runoff for the three unmined basins averaged 60 percent of the average annual precipitation; annual evapotranspiration losses averaged 40 percent. Of the total annual runoff, approximately 91 percent was surface and subsurface flow and 9 percent was ground-water discharge. Changes in storage in the soil zone and in the subsurface and groundwater reservoirs in the basin were negligible.

In contrast, simulations for the mined basins indicate that total annual runoff at Drawdy Creek averaged only 43 percent of average annual precipitation - the lowest of all study basins. The low total annual runoff probably results primarily from increased recharge of precipitation and runoff losses to ground water in rocks and in underground mines. Most of the increase in ground-water storage is assumed to be lost to a ground-water sink - that is, interbasin transfer of ground water by natural drainage and (or) mine pumpage from underground mines that extend into adjacent basins. Simulations indicate that interbasin transfer of ground water from Drawdy Creek basin averaged 8 percent of average annual precipitation. Annual evapotranspiration losses in Drawdy Creek basin averaged 49 percent of precipitation. Of the total annual runoff, approximately 74 percent was surface and subsurface runoff and 26 percent was ground-water discharge.

Simulations for Brier Creek basin indicate that total annual runoff averaged about 52 percent of average annual precipitation, annual evapotranspiration losses averaged 43 percent, and ground-water-sink losses averaged 5 percent. Of the total annual runoff, 79 percent was surface and subsurface runoff and 21 percent was ground-water discharge.

Results of model simulations with hypothetical mining conditions in Drawdy Creek basin for water years 1970-74 and in Brier Creek basin for water years 1971-73 show that streamflow characteristics, the water budget, and the seasonal distribution of streamflow in the basins would be significantly modified in response to increased mining in the basins. Simulations indicate that the effects of increasing mining from a hypothetical unmined condition to twice the actual mining condition in each of the basins would be to increase low flows and to decrease medium and moderately high flows. High flows in response to intense rainfall would become similar in both basins, regardless of the magnitude of mining in the basins.

Simulations for the hypothetical unmined condition and for twice the actual mined condition indicate that average total annual runoff in Drawdy Creek and Brier Creek basins would decrease by about 26 and 9 percent, respectively. These decreases would primarily reflect surface and subsurface flow losses and increased recharge of precipitation to ground water in the rocks and in underground mines. Average annual recharge in Drawdy Creek and Brier Creek basins would increase by about 134 and 37 percent, respectively. The increase in recharge would significantly increase ground-water storage in the basins, which in turn would be depleted mostly by increased losses to ground-water sinks and to base flow in streams during dry periods.

Simulations further indicate that surface- and subsurface-flow losses in the mined basins would occur throughout most of the year. These losses would be greatest during winter and spring and least during summer and fall. Ground-water discharge during winter and spring also would decrease, whereas during summer and fall, groundwater discharge would increase substantially. Model analysis indicates that if mining were doubled the average monthly base flow during September would increase by about 430 percent at Drawdy Creek and 100 percent at Brier Creek over the unmined condition.

Results of the study may have transfer value to other geographical areas in Central Appalachia having similar topographic, geologic, and hydrologic settings and coalmining activities (surface mines in combination with underground mines).

This study may be considered a practical example of the use of watershed models for estimating the hydrologic characteristics of ungaged basins and for predicting the hydrologic effects of coal mining. Climatic data that drive the model-daily precipitation, air temperature, and panevaporation data-may be readily available from the literature, may be measured at climatic stations in the ungaged area, or may be extrapolated from other, nearby stations. Measurable basin physical characteristics such as drainage area, land and channel slopes, aspects (general compass direction of land slope), and altitude and vegetation cover can be obtained from U.S. Geological Survey 71/2-minute topographic maps; soil types and characteristics can be obtained from U.S. Soil Conservation Service soils maps and surveys; land use can be obtained from U.S. Geological Survey land-use maps (scale 1:250,000), from color infrared photography or from other, more recent aerial photographic coverage of the study area. 


\section{REFERENCES CITED}

Bain, G.L., and Friel, E.A., 1972, Water resources of the Little Kanawha River basin, West Virginia: West Virginia Geological and Economic Survey River Basin Bulletin 2, 122 p.

Barlow, J.A., 1974, Coal and coal mining in West Virginia: West Virginia Geological and Economic Survey Coal-Geology Bulletin 2, 63 p.

Borchers, J.W., Ehlke, T.A., Mathes, M.V., and Downs, S.C., in press, The effects of coal mining on the hydrologic environment of selected stream basins in southern West Virginia: U.S. Geological Survey Water-Resources Investigations Report 84-4300.

Chang, Mingteh, Lee, Richard, and Dickerson, W.H., 1976 , Adequacy of hydrologic data for application in West Virginia: West Virginia University Water Resources Institute Bulletin 7, 145 p.

Dugolinsky, B.K., and Behling, M.C., compilers, 1978, 1978 West Virginia mineral producers directory: West Virginia Geological and Economic Survey Mineral Resource Series no. 1 (5th ed.), 155 p.

Ehlke, T.A., Runner, G.S., and Downs, S.C., 1982, Hydrology of Area 9, Eastern Coal Province, West Virginia: U.S. Geological Survey Water-Resources Investigations Report 81-803, 63 p.

Fenneman, N.M., and Johnson, D.W., 1946, Physical division of the United States: U.S. Geological Survey Map, scale 1:7,000,000 (reprinted 1964).

Hewlett, J.D., and Nutter, W.L., 1970, The varying source area of streamflow from upland basins: Paper presented at the symposium on Interdisciplinary Aspects of Watershed Management, Montana State University, August 3-6, 1970, 18 p.

Hobba, W.A., Jr., 1981, Effects of underground mining and mine collapse on the hydrology of selected basins in West Virginia: West Virginia Geological and Economic Survey Report of Investigations RI-33, $77 \mathrm{p}$.

Hopkins, H.T., 1970, Occurrence of fresh water in the Lee Formation in parts of Elliott, Johnson, Lawrence, Magoffin, and Morgan Counties, Eastern Coal Field region, Kentucky: U.S. Geological Survey Water-Supply Paper 1867, 44 p.

Latimer, W.J., 1915, Soil survey of Boone County, West Virginia: U.S. Department of Agriculture Bureau of Soils report, $26 \mathrm{p}$.

Leavesley, G.H., Jr., Lichty, R.W., Troutman, B.M., and Saindon, L.G., 1981, A precipitation-runoff modeling sys- tem for evaluating the hydrologic impacts of energy resources development: Paper presented at the Western Snow Conference, 49th, St. George, Utah, 1981, Proceedings, p. 65-76.

1983, Precipitation-Runoff Modeling System: User's manual: U.S. Geological Survey Water-Resources 1nvestigations Report 83-4238, 207 p

National Oceanic and Atmospheric Administration, 1973, Climatography of the United States no. 81-Monthly normals of temperature, precipitation, and heating and cooling degree days, 1941-70, West Virginia: Asheville, N.C., 9 p.

1977, Climatography of the United States no. 60-Climate of West Virginia: Asheville, N.C., 19 p.

Rosenbrock, H.H., 1960, An automatic method for finding the greatest or least value of a function: The Computer Journal, v. 3, p. 175-184.

Runner, G.S., 1980, Hydrologic data for runoff studies on small drainage areas: U.S. Geological Survey Open-File Report $80-560,169 \mathrm{p}$.

U.S. Geological Survey, 1979, Land use and land cover, 1972-73, Charleston, West Virginia; Ohio: U.S. Geological Survey Land Use Series Map L-57, scale 1:250,000.

1981, Land use and land cover, 1973-76, Bluefield, West Virginia; Virginia; Kentucky: U.S. Geological Survey Land Use Series Map L-109, scale 1:250,000.

U.S. Soil Conservation Service, 1967, Soil survey of Tucker County and parts of northern Randolph County, West Virginia: U.S. Department of Agriculture Soil Conservation Service and Forest Service report, 131 p.

1972, Soil survey of Greenbrier County, West Virginia: U.S. Department of Agriculture Soil Conservation Service report, $188 \mathrm{p}$.

1975, Soil survey of Fayette and Raleigh Counties, West Virginia: U.S. Department of Agriculture Soil Conservation Service report, $185 \mathrm{p}$.

1979, General soil map, West Virginia: Scale 1:750,000.

Ward, P.E., and Wilmoth, B.M., 1968, Ground-water hydrology of the Monongahela River basin in West Virginia: West Virginia Geological and Economic Survey River Basin Bulletin 1, $54 \mathrm{p}$.

Weeks, J.B., Leavesley, G.H., Jr., Welder, F.A., and Saulnier, G.J., Jr., 1974, Simulated effects of oil-shale development on the hydrology of Piceance basin, Colorado: U.S. Geological Survey Professional Paper 908, 84 p.

Younos, T.M., and Shanholtz, V.O., 1980, Soil texture and hydraulic properties of postmining soil as related to the premining soil horizons: Symposium on Surface Mining Hydrology, Sedimentology, and Reclamation, University of Kentucky, Lexington, December 1-5, 1980, Proceedings, p. 153-157. 


\section{APPENDIX A-PRECIPITATION-RUNOFF MODELING SYSTEM PARAMETERS AND VARIABLES}

Table

A-1 Monthly values for climatic variables used for study sites

A-2 Variables and associated values used in defining climatic data

A-3 Parameters for daily runoff computations defined by calibration for each site
Page

43

46

47 
Table A-1. Monthly values for climatic variables used for study sites

PAT, the maximum alr temperature (In degrees Celstus) which, when exceeded, forces preclpltation to be raln regardless of minimum temperature.

AJMX, adjustment factor for proportion of rain in a raln-snow mix event.

TLX, lapse rate for maxtmum dally alr temperature.

TLN, lapse rate for mlntmum dally alr temperature.

EVC, evaporation-pan coefflclent.

RDM, slope of maximum-minlmum alr temperature-sky cover relationsh1p.

RDC, $Y$-1ntercept of maximum-mintmum alr temperature-sky cover relationshlp.

\begin{tabular}{|c|c|c|c|c|c|c|c|}
\hline \multicolumn{8}{|c|}{ Climat le varlable } \\
\hline Month & PAT & ANTXX & $\operatorname{Tix}$ & TLN & EVC & RDM & $\mathrm{RDC}$ \\
\hline \multicolumn{8}{|c|}{ Horsecamp Run at Harman, W. Va. (s1te 1) } \\
\hline Jan. & 4.5 & 1.00 & 1.5 & 1.5 & 0.24 & -0.10 & 2.15 \\
\hline Feb. & 4.5 & 1.00 & 1.5 & 1.5 & .24 & -.10 & 2.15 \\
\hline Mar. & 0 & 1.00 & 1.5 & 1.5 & .24 & -.10 & 2.15 \\
\hline Apr. & $\mathbf{0}$ & 1.00 & 1.5 & 1.5 & .40 & -.10 & 2.15 \\
\hline May & 0 & 1.00 & 1.5 & 1.5 & .59 & -.07 & 1.64 \\
\hline June & 0 & 1.00 & 1.5 & 1.5 & .89 & -.07 & 1.64 \\
\hline July & $\mathbf{0}$ & 1.00 & 1.5 & 1.5 & 1.00 & -.07 & 1.64 \\
\hline Aug. & 0 & 1.00 & 1.5 & 1.5 & 1.00 & -.07 & 1.64 \\
\hline Sept. & 0 & 1.00 & 1.5 & 1.5 & .89 & -.07 & 1.64 \\
\hline oct. & 0 & 1.00 & 1.5 & 1.5 & .57 & -.07 & 1.64 \\
\hline Nov. & 0 & 1.00 & 1.5 & 1.5 & .34 & -.10 & 2.15 \\
\hline Dec. & 0 & 1.00 & 1.5 & 1.5 & .19 & -.10 & 2.15 \\
\hline
\end{tabular}


Table A-1. Monthly values for climatic variables used for study sites-Continued

\begin{tabular}{|c|c|c|c|c|c|c|c|}
\hline Month & PAT & AvMX & TLX & TLN & EVC & RDM & RDC \\
\hline \multicolumn{8}{|c|}{ Gilmer Run near Marlinton, w. Va. (site 2) } \\
\hline Jan. & $\mathbf{0}$ & 1.00 & 1.5 & 1.5 & 0.24 & -0.10 & 2.15 \\
\hline Feb. & 0 & 1.00 & 1.5 & 1.5 & .24 & -.10 & 2.15 \\
\hline Mar. & $\mathbf{0}$ & 1.00 & 1.5 & 1.5 & .24 & -.10 & 2.15 \\
\hline Apr . & 0 & 1.00 & 1.5 & 1.5 & .40 & -.10 & 2.15 \\
\hline May & 0 & 1.00 & 1.5 & 1.5 & .59 & -.07 & 1.64 \\
\hline June & 0 & 1.00 & 1.5 & 1.5 & .89 & -.07 & 1.64 \\
\hline July & 0 & 1.00 & 1.5 & 1.5 & 1.00 & -.07 & 1.64 \\
\hline Aug. & 0 & 1.00 & 1.5 & 1.5 & 1.00 & -.07 & 1.64 \\
\hline Sept. & 0 & 1.00 & 1.5 & 1.5 & .89 & -.07 & 1.64 \\
\hline oct. & 0 & 1.00 & 1.5 & 1.5 & .57 & -.07 & 1.64 \\
\hline Nov. & 0 & 1.00 & 1.5 & 1.5 & .34 & -.10 & 2.15 \\
\hline Dec. & 0 & 1.00 & 1.5 & 1.5 & .19 & -.10 & 2.15 \\
\hline \multicolumn{8}{|c|}{ Collison Creek near Nallen, w. Va. (site 3) } \\
\hline Jan. & 0 & 1.00 & 1.5 & 1.5 & 0.24 & -0.10 & 2.15 \\
\hline Feb. & 0 & 1.00 & 1.5 & 1.5 & .24 & -.10 & 2.15 \\
\hline Mar. & 0 & 1.00 & 1.5 & 1.5 & .24 & -.10 & 2.15 \\
\hline Apr. & 0 & 1.00 & 1.5 & 1.5 & .40 & -.10 & 2.15 \\
\hline May & 0 & 1.00 & 1.5 & 1.5 & .59 & -.07 & 1.64 \\
\hline June & 0 & 1.00 & 1.5 & 1.5 & 1.5 & -.07 & 1.64 \\
\hline July & 0 & 1.00 & 1.5 & 1.5 & 2.0 & -.07 & 1.64 \\
\hline Aug. & 0 & 1.00 & 1.5 & 1.5 & 2.0 & -.07 & 1.64 \\
\hline Sept. & 0 & 1.00 & 1.5 & 1.5 & 2.0 & -.07 & 1.64 \\
\hline oct. & 0 & 1.00 & 1.5 & 1.5 & 2.0 & -.07 & 1.64 \\
\hline Nov. & 0 & 1.00 & 1.5 & 1.5 & 1.5 & -.10 & 2.15 \\
\hline Dec. & 0 & 1.00 & 1.5 & 1.5 & .19 & -.10 & 2.15 \\
\hline
\end{tabular}


Table A-1. Monthly values for climatic variables used for study sites-Continued

\begin{tabular}{|c|c|c|c|c|c|c|c|}
\hline \multicolumn{8}{|c|}{ Climatic Variable } \\
\hline Month & PAT & AJMX & TLX & TLN & EVC & RDM & $\mathbf{R D C}$ \\
\hline \multicolumn{8}{|c|}{ Drawdy Creek near } \\
\hline Jan. & 1.0 & 0.80 & 1.5 & 1.5 & 0.24 & -0.10 & 2.15 \\
\hline Feb. & 1.0 & .80 & 1.5 & 1.5 & .24 & -.10 & 2.15 \\
\hline Mar. & $\mathbf{0}$ & .80 & 1.5 & 1.5 & .24 & -.10 & 2.15 \\
\hline Apr. & 0 & .80 & 1.5 & 1.5 & .40 & -.10 & 2.15 \\
\hline May & 0 & .80 & 1.5 & 1.5 & .59 & -.07 & 1.64 \\
\hline June & $\mathbf{0}$ & .80 & 1.5 & 1.5 & .89 & -.07 & 1.64 \\
\hline July & 0 & .80 & 1.5 & 1.5 & 2.00 & -.07 & 1.64 \\
\hline Aug. & 0 & .80 & 1.5 & 1.5 & 2.00 & -.07 & 1.64 \\
\hline sept. & 0 & .80 & 1.5 & 1.5 & 2.00 & -.07 & 1.64 \\
\hline oct. & 0 & .80 & 1.5 & 1.5 & 1.00 & -.07 & 1.64 \\
\hline Nov. & 0 & .80 & 1.5 & 1.5 & 1.00 & -.10 & 2.15 \\
\hline Dec. & 0 & .80 & 1.5 & 1.5 & .19 & -.10 & 2.15 \\
\hline \multicolumn{8}{|c|}{ Brier Creek at Fanrock, w. Va. (site 5) } \\
\hline Jan. & 4.0 & 1.00 & 1.5 & 1.5 & 0.24 & -0.10 & 2.15 \\
\hline Feb. & 4.0 & 1.00 & 1.5 & 1.5 & .24 & -.10 & 2.15 \\
\hline Mar. & 4.0 & 1.00 & 1.5 & 1.5 & .24 & -.10 & 2.15 \\
\hline Apr. & 4.0 & 1.00 & 1.5 & 1.5 & .40 & -.10 & 2.15 \\
\hline May & 0 & 1.00 & 1.5 & 1.5 & .59 & -.07 & 1.64 \\
\hline June & 0 & 1.00 & 1.5 & 1.5 & .89 & -.07 & 1.64 \\
\hline July & 0 & 1.00 & 1.5 & 1.5 & 1.00 & -.07 & 1.64 \\
\hline Aug. & 0 & 1.00 & 1.5 & 1.5 & 1.10 & -.07 & 1.64 \\
\hline sept. & 0 & 1.00 & 1.5 & 1.5 & 1.20 & -.07 & 1.64 \\
\hline oct. & 0 & 1.00 & 1.5 & 1.5 & 1.00 & -.07 & 1.64 \\
\hline Nov. & 0 & 1.00 & 1.5 & 1.5 & 1.00 & -.10 & 2.15 \\
\hline Dec. & 4.0 & 1.00 & 1.5 & 1.5 & .19 & -.10 & 2.15 \\
\hline
\end{tabular}


Table A-2. Variables and associated values used in defining climatic data

\begin{tabular}{|c|c|c|c|c|c|c|}
\hline Variable & Description & Site 1 & Site 2 & Site 3 & Site 4 & Site 5 \\
\hline PARS & $\begin{array}{l}\text { Predicted solar radiation correction factor } \\
\text { for summer day with precipitation. }\end{array}$ & 0.50 & 0.50 & 0.80 & 0.80 & 0.80 \\
\hline PARW & $\begin{array}{l}\text { Predicted solar radiation correction factor for } \\
\text { winter day with precipitation. }\end{array}$ & .40 & .40 & .80 & .80 & .80 \\
\hline RDMX & Maximum percent of potential solar radiation. & .80 & .80 & .80 & .80 & .80 \\
\hline CSEL & climate station elevation, in feet. & 1,922 & 2,100 & 1,757 & 675 & 1,280 \\
\hline RMXA & $\begin{array}{l}\text { Proportion of rain in a rain-snow precipitation } \\
\text { event above which snow albedo is not reset } \\
\text { (snow-pack accumulation state). }\end{array}$ & .80 & .80 & .80 & .80 & .80 \\
\hline RMXM & Same as RMXA but for snowpack stage. & .60 & .60 & .60 & .60 & .60 \\
\hline CTS & Air temperature ET coefficient. & .0106 & .0106 & .0106 & .0106 & .0106 \\
\hline TST & $\begin{array}{l}\text { Temperature index to determine specific data } \\
\text { for start of transpiration. }\end{array}$ & 1,400 & 1,400 & 1,400 & 1,400 & 1,400 \\
\hline CTW & $\begin{array}{l}\text { Proportion of potential evapotranspiration } \\
\text { that is sublimated from a snow surface } \\
\text { (decimal form). }\end{array}$ & 0 & 0 & 0 & 0 & 0 \\
\hline ISP 1 & $\begin{array}{l}\text { Julian date to start looking for spring } \\
\text { snowmelt stage. }\end{array}$ & 75 & 45 & 45 & 1 & 1 \\
\hline ISP2 & $\begin{array}{l}\text { Julian date to force snowpack to spring } \\
\text { snowmelt stage. }\end{array}$ & 90 & 90 & 90 & 1 & 1 \\
\hline EAIR & Enissivity of dry air. & .757 & .757 & .757 & .757 & .757 \\
\hline FWCAP & $\begin{array}{l}\text { Free water holding capacity of snowpack } \\
\text { expressed as a decimal fraction of total } \\
\text { snowpack water equivalent. }\end{array}$ & .04 & .04 & .04 & .04 & .04 \\
\hline DENI & Initial density of new-fallen snow. & .05 & .20 & .20 & .20 & .20 \\
\hline DENMX & Average maximum snowpack density. & .45 & .45 & .45 & .45 & .45 \\
\hline SETCON & Snowpack settlement time constant. & .10 & .05 & .05 & .05 & .05 \\
\hline BST & $\begin{array}{l}\text { Temperature above which precipitation is all } \\
\text { rain and below which it is all snow, in } \\
\text { degree Celsius. }\end{array}$ & -1.00 & -1.00 & -1.00 & 0 & 2.0 \\
\hline RDB & Sky cover solar-radiation computation. & .22 & .22 & .22 & .22 & .22 \\
\hline RDP & Sky cover solar-radiation computation. & .61 & .61 & .61 & .61 & .61 \\
\hline
\end{tabular}




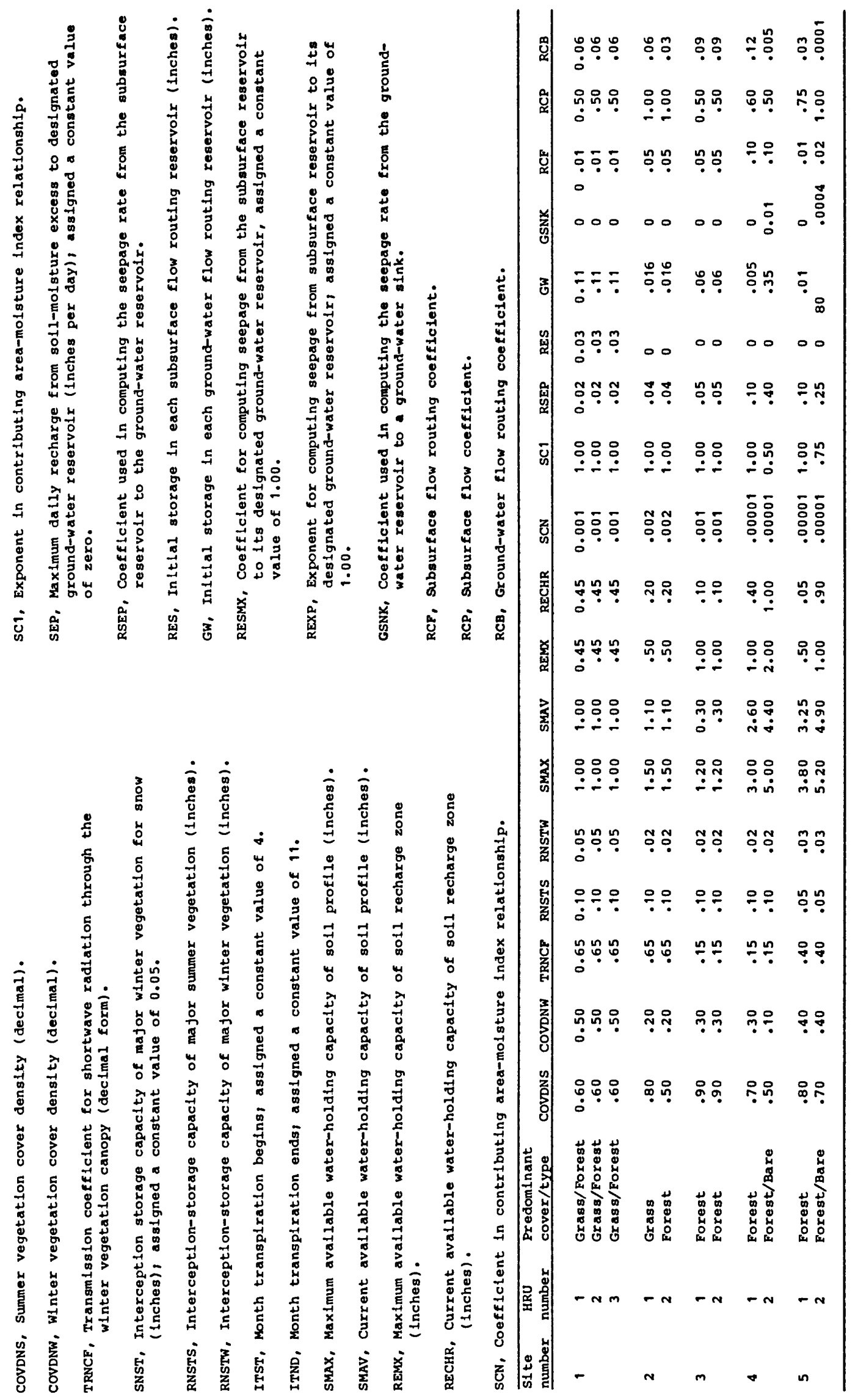




\section{METRIC CONVERSION FACTORS}

Inch-pound units of measurement in this report may be converted to metric (International System) units by using the following factors:

Multiply inch-pound unit

inch (in)

foot $(f t)$

mile (mi)

foot per mile (ft/mi)

square mile $\left(m i^{2}\right)$

acre

cubic foot per second $\left(\mathrm{ft}^{3} / \mathrm{s}\right)$

cublc foot per second per square mile $\left[\left(\mathrm{ft}^{3} / \mathrm{s}\right) / \mathrm{mi}^{2}\right]$

inch per hour (in/hr)

inch per day (in/d)
By

To obtain metric unit

Length

25.4

2.54

0.3048

1.6090

0.1894

Area

2.590

0.4047

Flow

0.02832

0.01093

\section{$\underline{\text { Rate }}$}

25.4

25.4 millimeter (mm)

centimeter $(\mathrm{cm})$

meter (m)

kilometer $(\mathrm{km})$

meter per kilometer $(\mathrm{m} / \mathrm{km})$

square kilometer $\left(\mathrm{km}^{2}\right)$

hectare (ha)

cubic meter per second $\left(\mathrm{m}^{3} / \mathrm{s}\right)$

cubic meter per second per square kilometer $\left[\left(\mathrm{m}^{3} / \mathrm{s}\right) /\right]$

\section{Temperature}

degree Fahrenheit $\left({ }^{\circ} \mathrm{F}\right)$

${ }^{\circ} \mathrm{C}=5 / 9\left({ }^{\circ} \mathrm{F}-32\right)$ degree Celsius $\left({ }^{\circ} \mathrm{C}\right)$

Sea level: In this report "sea level" refers to the National Geodetic Vertical Datum of 1929 (NGVD of 1929)--a geodetic datum derived from a general adjustment of the first-order level nets of both the United States and Canada, formerly called "Sea Level Datum of 1929." 